The Center for International Forestry Research (CIFOR) is a leading international forestry research organisation established in 1993 in response to global concerns about the social, environmental, and economic consequences of forest loss and degradation. CIFOR is dedicated to developing policies and technologies for sustainable use and management of forests, and for enhancing the well-being of people in developing countries who rely on tropical forests for their livelihoods. CIFOR is one of the 15 centres supported by the Consultative Group on International Agricultural Research (CGIAR). With headquarters in Bogor, Indonesia, CIFOR has regional offices in Brazil, Burkina Faso, Cameroon and Zimbabwe, and it works in over 30 other countries around the world.

\section{Donors}

The Center for International Forestry Research (CIFOR) receives its major funding from governments, international development organizations, private foundations and regional organizations. In 2005, CIFOR received financial support from Australia, Asian Development Bank (ADB), Belgium, Brazil, Canada, China, Centre de coopération internationale en recherche agronomique pour le développement (CIRAD), Cordaid, Conservation International Foundation (CIF), European Commission, Finland, Food and Agriculture Organization of the United Nations (FAO), Ford Foundation, France, German Agency for Technical Cooperation (GTZ), German Federal Ministry for Economic Cooperation and Development (BMZ), Indonesia, International Development Research Centre (IDRC), International Fund for Agricultural Development (IFAD), International Tropical Timber Organization (ITTO), Israel, Italy, The World Conservation Union (IUCN), Japan, Korea, Netherlands, Norway, Netherlands Development Organization, Overseas Development Institute (ODI), Peruvian Secretariat for International Cooperation (RSCI), Philippines, Spain, Sweden, Swedish University of Agricultural Sciences (SLU), Switzerland, Swiss Agency for the Environment, Forests and Landscape, The Overbrook Foundation, The Nature Conservancy (TNC), Tropical Forest Foundation, Tropenbos International, United States, United Kingdom, United Nations Environment Programme (UNEP), World Bank, World Resources Institute (WRI) and World Wide Fund for Nature (WWF). 


\title{
Forest Rehabilitation in Vietnam Histories, realities and future
}

\author{
Wil de Jong \\ Do Dinh Sam \\ Trieu Van Hung
}

Forest Science Institute of Vietnam

Center for International Forestry Research

Center for Integrated Area Studies, Kyoto University

In collaboration with

WWF, Indochina Office, Hanoi

Department of Forestry, MARD

Tropenbos International - Vietnam

International Cooperation Department, MARD

Forest Sector Support and Partnership Program 
All rights reserved. Published in 2006

Printed by Harapan Prima, Jakarta, Indonesia

(c) Center for International Forestry Research

For further information, please contact:

Center for International Forestry Research (CIFOR)

P.O. Box 6596 JKPWB

Jakarta 10065, Indonesia

Tel.: +62 (251) 622622, Fax: +62 (251) 622100

E-mail: cifor@cgiar.org

Website: http://www.cifor.cgiar.org

Cover photos by Christian Cossalter and Yayasan Diantama, Pontianak

Cover design by Eko Prianto

Design and layout by Vidya Fitrian and Catur Wahyu

National Library of Indonesia Cataloging-in-Publication Data

Forest rehabilitation in Vietnam: histories, realities and future/ by Wil de Jong, Do Dinh Sam, Trieu Van Hung. Bogor, Indonesia: Center for International Forestry Research (CIFOR), 2006.

ISBN 979-24-4652-4

$76 \mathrm{p}$.

CABI thesaurus: 1. rehabilitation 2. forests 3 . forestry 4 . forest economics 5 . history 6 . forest policy 7. Vietnam I. Title II. Do Dinh Sam III. Trieu Van Hung

Published by

Center for International Forestry Research

JI. CIFOR, Situ Gede, Sindang Barang

Bogor Barat 16680, Indonesia 


\section{Table of Contents}

List of Acronyms

Preface

viii

Chapter 1. Introduction $\quad 1$

Conceptual Clarification $\quad 2$

Forest Degradation and Rehabilitation $\quad 2$

A Conceptual Model of Forest Rehabilitation 4

Methodology 5

$\begin{array}{ll}\text { Introduction to the Field Study } & 7\end{array}$

Chapter 2. Forests and Forestry in Vietnam 11

$\begin{array}{ll}\text { Vietnam's Natural Conditions } & 11\end{array}$

Current Forest Status $\quad 12$

Changes in Forest Cover $\quad 13$

$\begin{array}{ll}\text { Special-Use Forests } & 15\end{array}$

$\begin{array}{ll}\text { Land Targeted for Forest Rehabilitation } & 15\end{array}$

$\begin{array}{ll}\text { Forestry Economics } & 17\end{array}$

$\begin{array}{ll}\text { Vietnam's Dependence on its Forest Sector } & 17\end{array}$

Wood Pulp, Paper and other Wood Processing Industries 19

$\begin{array}{ll}\text { Future Demands for Timber and NTFPs } & 19\end{array}$

$\begin{array}{ll}\text { Environment Services and Tourism } & 21\end{array}$

Institutions and Policies Related to Forest Restoration in Vietnam 22

$\begin{array}{ll}\text { Organizational Structure of Vietnam's Forest Sector } & 22\end{array}$

$\begin{array}{ll}\text { State Forest Enterprises } & 24\end{array}$

Forest and Other Relevant Policies $\quad 25$

Forest Land Allocation $\quad 26$

Forest Land Contracts (Decree No. 01/CP, 1994) 28 
$\begin{array}{lr}\text { Investment and Credit Policies } & 29\end{array}$

Policies on Benefit Sharing and Tax Reductions $\quad 30$

Chapter 3. Histories of Forest Rehabilitation 33

Early Forest Rehabilitation Efforts $\quad 33$

Scattered Tree Planting $\quad 35$

$\begin{array}{ll}\text { World for Food Program } & 35\end{array}$

Rehabilitated Forests at the Beginning of the Large Programs 36

Contemporary Forest Rehabilitation in Vietnam $\quad 38$

The Greening the Barren Hills Program $\quad 38$

$\begin{array}{ll}\text { Achievements } & 39\end{array}$

The Five Million Hectare Reforestation Project $\quad 41$

$\begin{array}{ll}\text { Achievements } & 42\end{array}$

International Contributions to Program 327 and 5MHRP 43

Chapter 4. A Survey of Forest Rehabilitation Projects 45

An Overview of Forest Rehabilitation Projects in Vietnam $\quad 45$

$\begin{array}{ll}\text { Protection Forest Rehabilitation Projects } & 47\end{array}$

Special-use Forest Rehabilitation Projects $\quad 47$

$\begin{array}{ll}\text { Projects on Production Forest Land } & 47\end{array}$

$\begin{array}{ll}\text { Projects Supporting Forest Rehabilitation Projects } & 48\end{array}$

Features of Vietnam's Forest Rehabilitation Projects $\quad 48$

$\begin{array}{ll}\text { Objectives and Duration } & 51\end{array}$

Outcomes of Vietnam's Forest Rehabilitation Projects 55

$\begin{array}{ll}\text { Reasons for Outcomes } & 60\end{array}$

Chapter 5. Lessons Learnt 63

The Results of 50 Years of Forest Rehabilitation $\quad 64$

$\begin{array}{ll}\text { Explaining Outcomes } & 65\end{array}$

$\begin{array}{ll}\text { Policy and Legislation } & 65\end{array}$

$\begin{array}{ll}\text { Actors and Arrangements } & 67\end{array}$

$\begin{array}{ll}\text { Funding } & 68\end{array}$

Objectives of Rehabilitation $\quad 68$

$\begin{array}{ll}\text { Economics, Markets and Demand } & 69\end{array}$

Technology, Extension, Technical Assistance and Training 69

Lessons learnt $\quad 70$

$\begin{array}{ll}\text { References } & 73\end{array}$ 


\section{Figures}

Figure 1. Changes in Vietnam's forest cover 1976-2004 14

Figure 2a. Average annual forest plantation establishment for five-year intervals 34

Figure 2b. Accumulative plantation establishment 1961-2000 [ha] 34

Figure 3. Number of projects by ecological region and type of forest 46

Figure 4. Beginning and duration of forest rehabilitation projects 52

\section{Tables}

Table 1. Clarification of forest rehabilitation terminology 4

Table 2. Factors that influence forest rehabilitation outcomes 5

Table 3. Information collected in the general inventory of forest rehabilitation projects $\quad 7$

Table 4. Forest types in Vietnam, 2004 [1000 ha] 12

Table 5. Vietnam's forest cover throughout different periods [1000 ha] 13

Table 6. Commercial plantations by Region [1000 ha] 14

Table 7. Vietnam's special-use forest status [ha] 15

Table 8. Current status of unused land area in Vietnam, 2003 [ha] 16

Table 9. Current status of unused land area in Vietnam by region, 2003 [ha] 16

Table 10. Household incomes from agriculture, forestry and fisheries [\%] 18

Table 11. Vietnam forest product exports 1996-2005 [million USD] 18

Table 12. Forecast of Vietnam's saw log and wood-based panel consumption $\left[1000 \mathrm{~m}^{3}\right] \quad 20$

Table 13. Vietnam's forecasted paper consumption [1,000 tons] 20

Table 14. Forecasted timber and forest product demands 2006-2020 20

Table 15. National policies affecting forest rehabilitation in Vietnam (1991-2006) 27

Table 16. Forest land allocated and leased to households and foreign and joint venture companies [2003, ha] 28

Table 17. 5MHRP investments [1998-2005; million VND] 30

Table 18. Planted forests in Vietnam between 1986 and 199236

Table 19. Sources of the 5MHRP investments 42

Table 20. Achievements of 5MHRP projects from 1998 to 2003 [ha] 43

Table 21. Projects by forest type, region and source of funding 46

Table 22. Area coverage of reviewed rehabilitation projects 49

Table 23. Dominant topography of forest rehabilitation projects 49

Table 24. Soil fertility in forest rehabilitation projects 50

Table 25. Causes of degradation leading to forest rehabilitation projects $\quad 50$

Table 26. Forest rehabilitation project objectives 51 
Table 27. Beneficiaries of forest rehabilitation projects 52

Table 28. Project executing agencies 53

Table 29. Funding sources for forest rehabilitation projects 53

Table 30. Main project funding sources $\quad 54$

Table 31. Rehabilitation methods used $\quad 54$

Table 32. Achievement of project objectives in forest rehabilitation projects 55

Table 33. Success rating of forest rehabilitation projects 55

Table 34. Achievements of 42 forest rehabilitation projects 57

Table 35. Project outcomes for local people of 15 forest rehabilitation projects in Vietnam 58

Table 36. Marketable products produced from forest rehabilitation projects $\quad 59$

Table 37. Pre-project and current forest cover in 42 forest rehabilitation projects 59

Table 38. Environmental changes in 15 rehabilitation projects 59

Table 39. Reasons for achievements in 15 projects 60

Table 40. Management improvements in 15 forest rehabilitation projects $\quad 61$

Table 41. Acceptance of forest rehabilitation projects 62 


\section{List of Acronyms}

5MHRP Five Million Hectare Reforestation Project

ADB

Asian Development Bank

CIFOR

Center for International Forestry Research

COP7

Seventh Meeting of the Conference of the Parties to the Convention on Biological Diversity

DARD Department of Agriculture and Rural Development

DANIDA Danish International Development Assistance

$\mathrm{DPC}$

District People's Committee

EU

European Union

FAO

Food and Agricultural Organization

FIPI

Forest Inventory and Planning Institute

FPD

Forest Protection Department

FPsD

Forest Protection Sub Department

FSIV

Forest Science Institute Vietnam

GDP

Gross Domestic Product

GEF

Global Environment Facility

GoV

Government of Vietnam

GSO

Government Statistics Office

GTZ

German Development Cooperation Agency

JBIC

Japan Bank for International Cooperation

KfW

German Development Bank

MARD

Ministry of Agriculture and Rural Development

MDF

Medium Dense Fibre wood 
MONRE Ministry of Natural Resources

NTFP Non Timber Forest Products

ODA Overseas Development Assistance

PPC Provincial People's Committee

SFE State Forest Enterprise

SIDA Swedish International Development Assistance

UNCED United Nations Conference on the Environment and Development

UNDP United Nations Development Program

VND Vietnam Dong

WB World Bank

WFP (PAM) World Food Program

WWF Worldwide Fund for Nature 


\section{Preface}

Many tropical countries have achieved economic growth at the expense of converting their forests. Some of those countries have prospered and now have the resources and the will to restore some of the lost forest cover. Others remain impoverished despite converting forests. They, too, rely on rehabilitation to continue to gain benefits from their forests.

Forest rehabilitation is not a new phenomenon. But as tropical forest conversion continues seemingly unabated, rehabilitating degraded landscapes is likely to become more and more important. Countries—individually or collectively—will increasingly turn to rehabilitation to undo the negative consequences of diminishing forest cover. Countries that had or still have large forested areas, like Brazil, Indonesia and China, have initiated programs meant to restore millions of hectares.

Forest rehabilitation is a major concern for the Center for International Forestry Research (CIFOR) and its partners. Future benefits from forests will in many places only be assured if forests can be successfully rehabilitated. Downstream water quality and flows, biodiversity conservation, raw material supply and forest-based income for the poor will depend on it. CIFOR has, since its beginning, undertaken research programs and projects that address forest rehabilitation.

This report is one of six emerging from the study 'Review of forest rehabilitation: Lessons from the past'. This study attempted to capture the rich but underutilized experiences of many years of forest rehabilitation in Brazil, China, Indonesia, Peru, the Philippines and Vietnam, and make this information available to guide ongoing and future rehabilitation efforts. We present this and the other five study reports in the hope that the lessons they contain will be relevant for people who are concerned about tropical forests, and that as a result societies will continue to enjoy the benefits that tropical forests provided before there was a need to rehabilitate them.

The six-country study was carried out with generous contributions from the Government of Japan. The study on Vietnam would not have been possible without the generous help of many. In particular we thank members of collaborating agencies 
in Vietnam, and participants at two meetings that were held in Hanoi to provide input into the study. We also thank the many people who patiently provided information during interviews, and Kristen Evans, Unna Chokkalingam and Takeshi Toma for critically reviewing an earlier draft of the report.

Markku Kanninen

Director, Environmental Services and Sustainable Use of Forests Programme CIFOR 


\section{Chapter 1 Introduction}

As tropical countries across the globe have grown increasingly concerned about the consequences of forest conversion, they are attempting to reverse the trend. Worldwide efforts to 'rehabilitate' tropical forests have accelerated. Although largely a recent phenomenon, many tropical countries had already started forest rehabilitation during the first half of the $20^{\text {th }}$ century. The true era of forest rehabilitation, however, began in the late $20^{\text {th }}$ century. It was then that international donor agencies, the United Nations Food and Agriculture Organization (FAO) among others, created development assistance programs to provide funds and expertise for forest rehabilitation. Since then countries such as the Philippines, Brazil, Indonesia, China and Vietnam have initiated their own massive forest rehabilitation efforts.

The era of forest rehabilitation is still only beginning. Current land use and management dynamics and the socioeconomic and political economic forces that drive those trends will continue to leave countries with denuded landscapes where once forests stood. These are the unfortunate drivers that will in turn generate even more situations where forest restoration will be considered a feasible and rational alternative to other land use choices.

Future efforts will need better knowledge if they are to increase their impact and cost-efficiency. Previous forest rehabilitation experiences can provide important and valuable lessons for the future. For that reason, this report assesses the experiences of forest rehabilitation in Vietnam and draws strategic lessons from these experiences to guide new forest rehabilitation projects. The report highlights lessons from Vietnam's experiences that will be helpful beyond the country's border.

The study is part of a research effort carried out by the Center for International Forestry Research between 2003 and 2005 to learn lessons from forest rehabilitation efforts in six countries: Vietnam, China, Indonesia, the Philippines, Brazil and Peru. The study pursued similar objectives in each country (www.cifor.cgiar.org/rehab/).

This report has the following structure: the remainder of Chapter One provides the conceptual clarification and theoretical underpinnings for the study and introduces 
the methodology. Chapter Two provides background information and context for the outcomes of forest rehabilitation in Vietnam, including basic information on Vietnam, its forest cover, forestry sector and policies that are relevant to forestry and forest rehabilitation. Chapter Three gives an overview of forest rehabilitation in Vietnam from its inception in the 1950s until today, as the country carries out its latest nationwide forest rehabilitation effort, the 5 Million Hectares Reforestation Project. Chapter Four analyzes in detail forest rehabilitation projects that were analyzed in the field study carried out as part of this study. Chapter Five draws lessons from the report.

\section{Conceptual Clarification}

\section{Forest Degradation and Rehabilitation}

The goal of the larger research project of which this study forms a part is to 'Increase the long-term sustainability of current and future forest rehabilitation efforts on formerly forested lands with minimal negative impacts on different stakeholders.' This is to be achieved through 'Obtaining strategic lessons on driving forces, impacts, and underlying constraints from past and ongoing rehabilitation initiatives and research, identifying the most promising rehabilitation approaches under different ecological and socio-economic scenarios and identifying appropriate economic and institutional incentives under different conditions.' ${ }^{2}$ The study uses the following definition of forest rehabilitation initiatives: Deliberate activities aimed at artificial and/or natural regeneration of trees on formerly forested grasslands, brushlands, scrublands or barren areas for the purpose of enhancing productivity, livelihood andlor environmental service benefits.

In this report we use a modified definition of forest rehabilitation that better suits the conditions of Vietnam. We first define the term 'degradation of forests' as a process that leads to a loss of forest structure, native species diversity, the ecological processes that characterize natural forests, and productivity. This definition implies that conversion and extractive use both lead to degradation, even if this is economically and socially justified. We define degradation largely as an ecological process and do not express any value judgment about forest degradation. Nor do we discuss the social, cultural and economic dimensions that may lead to a breakdown of productive and sustainable forest management. Degradation in this sense may be justified, or it may be acceptable for one stakeholder group, if not for others. Degradation may be the result of activities that directly affect the vegetation (i.e. logging, slashing of forest, fires, wind) or components of the forest ecosystem, but not the forest directly (i.e. on water flow, soil properties or air quality).

\footnotetext{
1 Project circular: Review of forest rehabilitation initiatives - Lessons from the past. Revised version, May 2003, at www.cifor.cgiar.org/rehab/.

${ }^{2} \mathrm{Ibid}$
} 


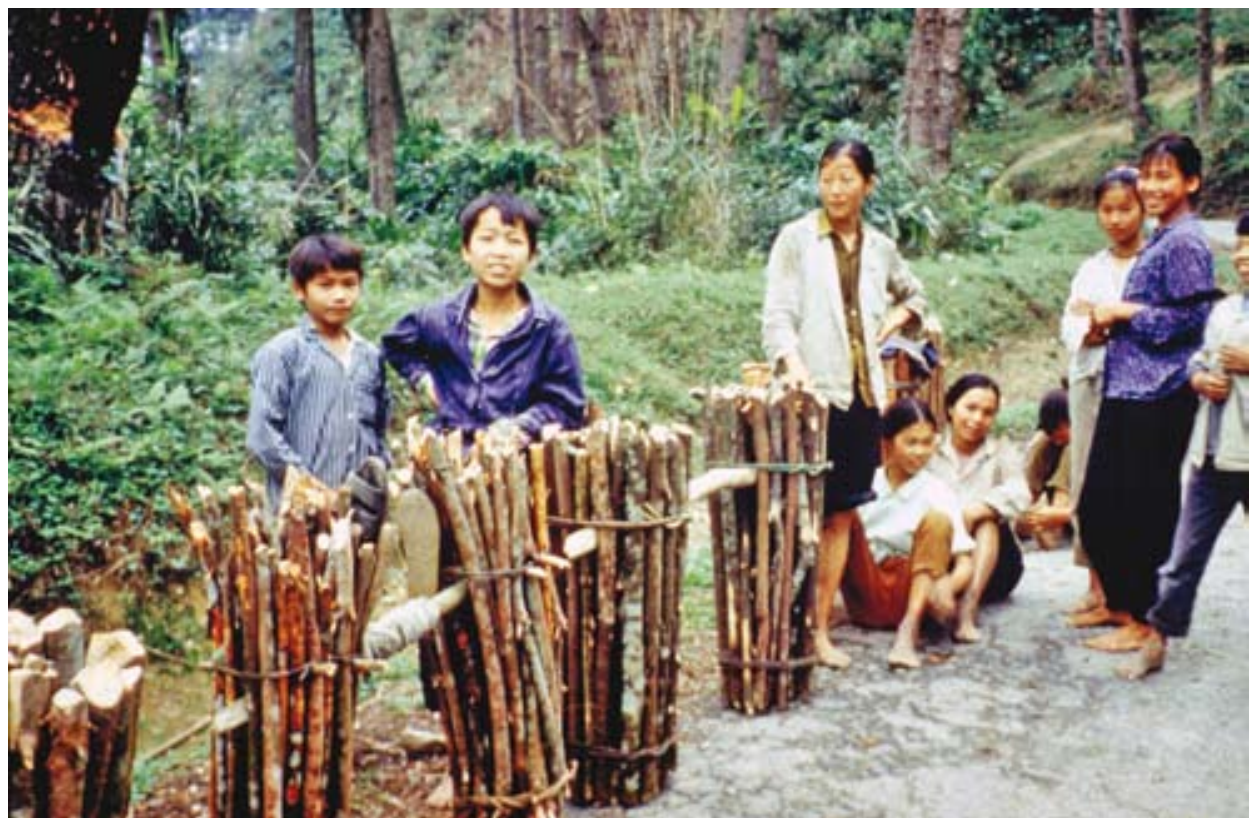

Firewood Collectors at Tam Dao near Hanoi. (Photo by John Turnbull)

We define forest rehabilitation as all deliberate activities that have as an outcome the reversal of forest degradation. We use this definition because, in the case of Vietnam, forest rehabilitation targets forestland that is under different degrees of degradation, i.e., not only formerly forested grasslands, brushlands, scrublands or barren areas.

Forest rehabilitation has been discussed at the conceptual level (e.g. Lamb and Gilmour 2003; Poulsen et al. 2002), and has been associated with various other terms (i.e. restoration, reclamation, reforestation, afforestation). For instance, Lamb and Gilmour (2003) suggest three groups of actions aimed at reversing forest degradation: reclamation, rehabilitation and restoration. By their definition, these activities have different expectations of improvements in biological diversity, structure and/or productivity. Reclamation has the objective of increasing the productivity of newlyestablished tree vegetation. Restoration aims at restoring the tree vegetation as close as possible to the original forest cover. Rehabilitation is an intermittent activity to restore productivity and biological diversity, but is less interested in achieving the level of biodiversity of the original forest.

The terminology gets confusing when we consider the COP7 definitions of reforestation and afforestation. Both refer to conversion of non-forest land through planting, seeding and/or promotion of natural seed sources (Smith 2002). ${ }^{3}$ The difference between reforestation and afforestation is the minimum amount of time that a particular area of land has not had forest cover, which is longer in the case of

\footnotetext{
${ }^{3}$ Afforestation takes place on land that has not been forested for at least 50 years, while reforestation happens on land that has not contained forest since 1990 (Smith 2002).
} 
afforestation. The difference between the COP7 and Lamb and Gilmour (2003) definitions is that the former refers to the act of putting back forests, defined as land having a tree crown cover greater than $10 \%$. Lamb and Gilmour's definitions appear to confound the intentionality and effect of forest rehabilitation. Reclamation, in their words, means returning unforested land to forested land principally for the purpose of production. This would be an act of reforestation or afforestation by the COP7 definition. In many cases of reclamation, less effort is made to restrain spontaneous vegetation growth. The result is the restoration of the biodiversity and ecological functions of the original forest, such as microclimate regulation, water flow regulation and carbon storage.

A possible alternative to Lamb and Gilmour's proposal could be a modified version of the typology of planted forests, developed by Poulsen et al. (2002) and summarized in Table 1. In the definition that we propose, all activities leading to these types of forest would be qualified as forest rehabilitation. This typology makes a more obvious link to actual ongoing practices, and it is also clearer what the main objectives and the ecological outcomes of each of these activities are. In several of the types included in the first column in Table 1, different ecological outcomes are possible.

Table 1. Clarification of forest rehabilitation terminology

\begin{tabular}{ll}
\hline $\begin{array}{l}\text { Typology of planted forests } \\
\text { (from Poulsen et al. 2002) }\end{array}$ & $\begin{array}{l}\text { Terminology proposed by } \\
\text { Lamb and Gilmour (2003) }\end{array}$ \\
\hline Industrial plantations & Reclamation \\
\hline Home and farm plantations & Reclamation/Rehabilitation \\
\hline Managed secondary forests with planting & Rehabilitation \\
\hline Managed secondary forest without planting & Rehabilitation \\
\hline $\begin{array}{l}\text { Planting or assisted natural regeneration for forest restoration } \\
\text { purposes }\end{array}$ & Restoration \\
\hline Protection of degraded natural forest or secondary forest & Restoration \\
\hline
\end{tabular}

\section{A Conceptual Model of Forest Rehabilitation}

The original research objectives ${ }^{4}$ state that the purpose of this report is to 1) draw strategic lessons on the driving forces, impacts and underlying constraints from past and ongoing rehabilitation initiatives and research; 2) to identify the most promising rehabilitation approaches under different ecological and socio-economic scenarios; and 3) to identify appropriate economic and institutional incentives under distinct conditions.

Once decision makers commit to forest rehabilitation, the next step is to clarify what are the related driving forces, constraints and social conditions that affect forest

\footnotetext{
${ }^{4}$ Project circular: Review of forest rehabilitation initiatives - Lessons from the past. Revised version, May 2003 at www.cifor.cgiar.org/rehab/.
} 
rehabilitation. In this section, we propose a conceptual model for identifying these factors and understanding the mechanisms that shape the relationships between these factors and forest rehabilitation outcomes.

Table 2 provides a list of seven groups of factors that influence forest rehabilitation outcomes that were identified by the five participants in the CIFOR study, at the workshop in Tsukuba, Japan in July 2005. ${ }^{5}$ Each of the 27 factors in Table 2 influences the outcomes of rehabilitation initiatives through their own mechanisms. In particular cases, different subsets of factors may be relevant. This allows for the formulation of enabling scenarios. For instance, the objectives of forest rehabilitation are more likely to be reached under the following conditions: if they address the causes of degradation, if they have been established through a mechanism of broader consultation, if distinct objectives are linked, if they are better communicated to relevant actors, and if they are flexible and can be adjusted when there appears a necessity to do so.

Rehabilitation efforts are likely to be more successful if the most appropriate technologies are available, if these technologies are adequately disseminated, if their selection has be the result of an inclusive process, and if the conditions for their adoption are right. The efforts are also more effective when adequately linked to the causes of degradation, objectives, site conditions, local arrangements, local needs and markets.

Similar narratives can be developed for each of the six groups of factors in Table 2. It becomes clear that as a rule, success in forest rehabilitation demands the definition of several factors: policies, economics, markets for the products and services generated by forest rehabilitation, funding, actors and arrangements, and finally extension and training.

These observations define the conceptual structure for this research study and report by providing the framework for drawing the strategic lessons on driving forces, impacts, and underlying constraints from past and ongoing rehabilitation initiatives and research. This framework can also identify the most promising rehabilitation approaches under different ecological and socio-economic scenarios. The factors in Table 2 are the elements of a dynamic model with initiatives of forest rehabilitation at one end, and the outcomes of those initiatives at the other. From an initial input in forest rehabilitation, the factors of Table 2 determine the status of the outcome variables.

\section{Methodology}

This study is based on three sources of information. We drew much of the data presented in this book from reports, studies and publications related to Vietnam's forestry sector and forest rehabilitation in general. In addition, our Vietnam research team carried out a field study during 2003 and 2004 that is described in detail in the next section. Third, we relied on information from many experts actively involved

\footnotetext{
${ }^{5}$ Takeshi Toma, Cesar Sabogal, Unna Chokkalingam, Ani Nawir and Wil de Jong.
} 
in forest rehabilitation activities in Vietnam, which was provided throughout the study. We interviewed these experts during the field study and at meetings where we presented our research concepts and progress.

Table 2. Factors that influence forest rehabilitation outcomes
A. Policies and legislation
1. Drivers behind policies
2. Credit facilities, payments for planting, payment for environmental services
3. Incentives and disincentives for degradation and rehabilitation
4. Sustainability of policies and political support
5. Tenure and interest in the outcomes of rehabilitation
6. Effectiveness and limitation of land zoning

\section{B. Players, actors and arrangements}

7. Organization, capacity, competition aspects

8. Social cohesion and conflicts

9. Adoption of forest rehabilitation by relevant players

10. Institutional arrangements and how they are influenced by conditions and objectives

11. Sustainability of arrangements

12. Intra-project communication; documentation of projects; communication of results

\section{Funding}

13. Amounts of funds invested

14. Main sources of funding. Effects of different types of funding on nature, outcomes, and cost effectiveness

15. Link between funding, funding types and continuity of forest rehabilitation

\section{Objectives of rehabilitation}

16. Link between objectives and causes of degradation

17. Process of determining objectives

18. Compatibility and competition between objectives

19. Communication to relevant players

20. Flexibility or inflexibility of objectives

\section{E. Economics, markets, demands}

21. Dynamics of markets, evolving wood industries

22. Use of marketing strategies in forest rehabilitation efforts

\section{F. Technology}

23. Availability and dissemination of available technologies

24. Appropriateness of technologies for the causes of degradation, objectives, site conditions, local arrangements, local needs and markets

25. Factors that define choice of technologies

26. Conditions that influence adoption

G. Extension, technical assistance and training

27. The contribution of extension and training on forest rehabilitation outcomes 


\section{Introduction to the Field Study}

\section{Step 1: A General Survey of Forest Rehabilitation Projects}

The research team collected information about as many forest rehabilitation projects in Vietnam as possible by consulting databases at various agencies under the Ministry of Agriculture and Rural Development (MARD) in Hanoi. MARD is the primary ministry responsible for forest rehabilitation (see Chapter Two). The team collected the data in Table 3 for each forest rehabilitation project:

Table 3. Information collected in the general inventory of forest rehabilitation projects

\begin{tabular}{l}
\hline Name of the project \\
\hline Purposes of the project \\
\hline Project location \\
\hline Project areas \\
\hline Source of project funds \\
\hline Amount of funds invested \\
\hline Species planted \\
\hline Starting date \\
\hline Ending date \\
\hline Donors and partners
\end{tabular}

We identified 304 forest rehabilitation projects, but not all data was available for each project. The data collection for this general survey took place between September 2003 and January 2004.

\section{Step 2: In-depth survey of 42 selected forest rehabilitation projects}

The second step of the study was to select 42 projects from the general survey for collecting more in-depth information. To do this we presented the results of the general survey at a national workshop, held in March 2004 in Hanoi. Thirty-five representatives from all prominent national and international forestry agencies and private sector institutions from Hanoi participated (See photo on page 8). Participants reviewed the criteria for the selection of the 42 projects.

Three criteria guided the selection of projects for Step 2. All 304 projects from the general survey were grouped according to forest type (protection, special-use and production forests—see Chapter Two), geographic location, and principal source of funding. Then 42 projects were selected to assure adequate representation along these three variables, which influenced relevant features of the projects. ${ }^{6}$ The availability

\footnotetext{
${ }^{6}$ Initially the plan was to conduct an analysis of 50 projects; for data availability reasons this number was reduced to only 42 projects.
} 


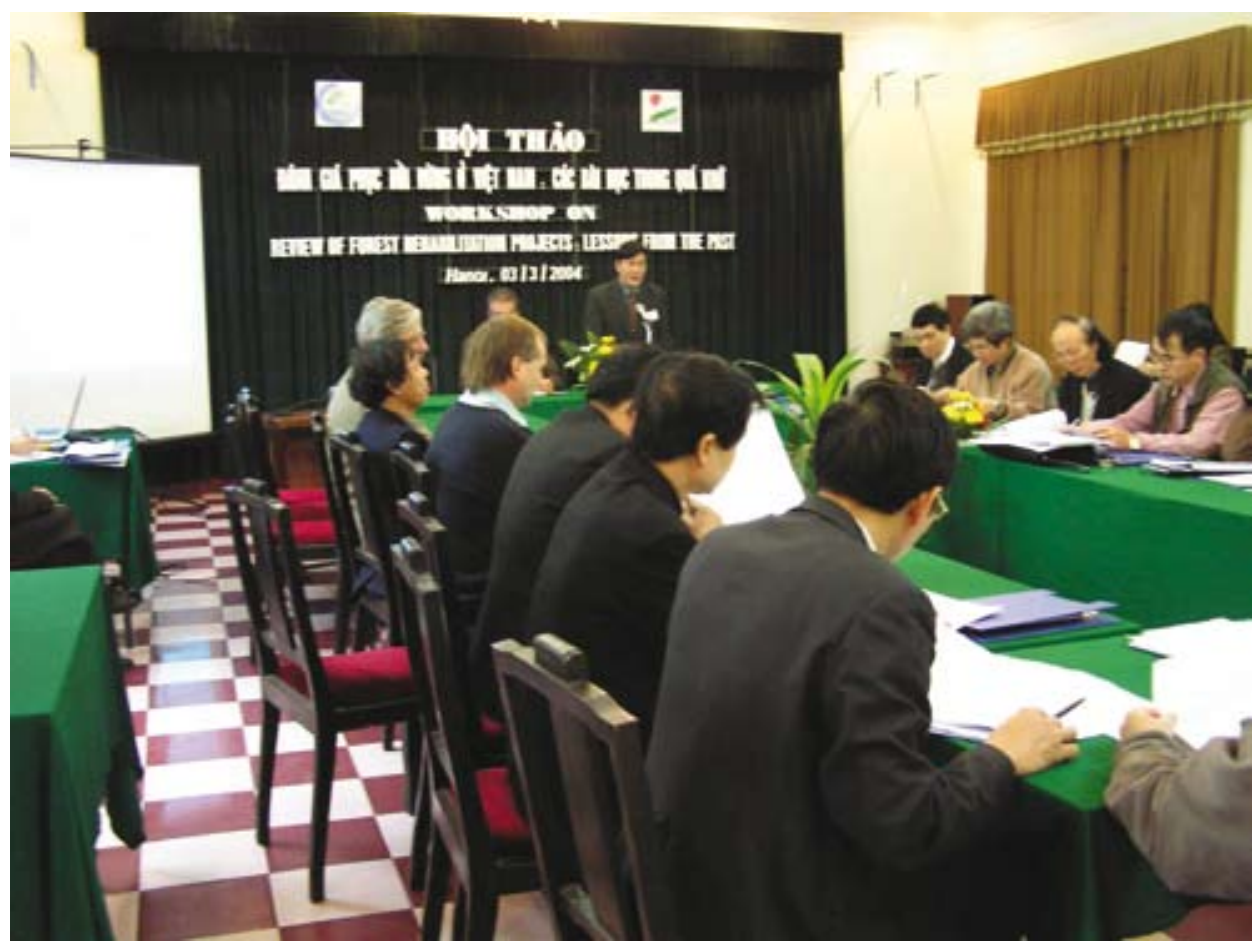

Report back meeting for the general survey. Hanoi, 3 March 2004. (Photo by FSIV)

of information was an additional defining criterion for the selection of projects. Participants provided suggestions on how and where to obtain this data.

For the in-depth analysis, the Vietnam team revised the questionnaire that had been prepared by the CIFOR research team. The questionnaire included the following types of information:

1. Basic project information

2. Technological aspects of the project design

3. Technical and environmental aspects related to the implementation of the projects

4. Socio-economic aspects related to the implementation of the projects

5. Institutional aspects related to the implementation of the projects

6. Project results

The information came from project reports, other documentation and interviews of people who were familiar with the selected projects. The data collection for this part of the study was completed during the first half of 2004 .

\section{Step 3: Field visit of a sub sample of projects}

The third step included field visits to a sub-selection of 15 projects. At these sites, members of the research team collected additional information by conducting interviews with provincial and district government offices, project personnel and local 
communities that have been affected by forest rehabilitation projects. The selection of the 15 projects was based on the same criteria as those used for the selection of the 42 projects. A new questionnaire was designed for the survey of these 15 projects. The questions focused in more detail on:

1. Environmental achievements

2. Impacts on livelihoods of local people

3. Technical results - production, growth, health

4. Conditions contributing to long-term sustainability

5. Acceptance of the project

The field visits were completed between June and August 2004.

The first full draft of this report was presented at a meeting in Hanoi on 28 February 2006, again attended by forestry and nature conservation government and development experts and by NGO representatives, and the input was incorporated in its subsequent revision. 



\section{Chapter 2}

\section{Forests and Forestry in Vietnam}

\section{Vietnam's Natural Conditions}

Vietnam has an elongated S-like shape, a total area of $331123 \mathrm{~km}^{2}$, and a north to south length of $1650 \mathrm{~km}$. The country is characterized by two main basic topographies. The coastal plains of the Red River delta and the Mekong delta are connected by a strip of coastal plain along the remainder of the country. Nearly three-quarters of the country's total territory is hilly, highland or high mountains that reach a maximum altitude of $3000 \mathrm{~m}$ in the Hoang Lien Son mountain range in the northwest. Because of its geography, only $15 \%$ of Vietnam's area is farm land.

Vietnam's climate is tropical monsoon; it is subject to the southwest monsoon from May to October and the northeast monsoon in winter. The country has two distinct climatic zones. From the $16^{\circ}$ latitude parallel to the north, winter lasts from December to February, but without a marked dry season. From the $16^{\circ}$ parallel southward, a marked dry season occurs from November to April. The average national rainfall is $1300-3200 \mathrm{~mm}$. In some areas near the Southeast Sea annual rainfall may be less than $500 \mathrm{~mm}$, while in some mountainous locations it may reach $4800 \mathrm{~mm}$. The annual average temperature is $21^{\circ} \mathrm{C}$ in the north and $27^{\circ} \mathrm{C}$ in the south.

The total population of Vietnam was 81 million in 2003, with an annual growth of $1.47 \%$ and an average population density of $245 / \mathrm{km}^{2}$. Three-quarters of the total population live in rural areas (GoV 2005). Vietnam's national economy grew fast after the economic reform in 1980s, with average economic growth in 1990s reaching 7.68\% (Nguyen T.Q. 2005).

Vietnam's complicated topography and climate explain its diversity of natural forests including mangrove forests, Melaleuca forests, muddy forests, monsoon forests, evergreen broad-leaved forests, semi-deciduous forests on high and low mountains, and on limestone rocky mountains and mixed evergreen coniferous forest on high mountains (Clarke n.d.). 


\section{Current Forest Status}

In 2004, Vietnam had a forest area of 12.3 million ha, comprising 10.1 million ha of natural forests $(81.3 \%)$ and 2.2 million ha of plantations $(28.7 \%)$. The national forest cover is $36.7 \%$. Forests are classified into three forest types: special-use, protection and production forests, as defined by the 1991Forest Protection and Development Law. The main role of special-use forests is nature conservation, protection of historical and cultural relics, tourism, and to some extent, environmental protection. Protection forests are maintained to protect water streams and soils, prevent soil erosion and mitigate natural disasters. Production forests have the main purpose of supplying timber and non-timber forest products (NTFPs), but in addition provide environmental protection. In 2004 Vietnam had 1.9 million ha of special-use forest (15.44\%), 5.9 million ha of protection forests (48.1\%) and 4.4 million ha of production forest $(36.46 \%)$. A correlation between forest types according to forest objectives criteria and habitat criteria is shown in Table 4.

Table 4. Forest types in Vietnam, 2004 [1000 ha]

\begin{tabular}{|c|c|c|c|c|}
\hline \multirow{2}{*}{ Forest types } & \multirow{2}{*}{ Total } & \multicolumn{3}{|c|}{ Forest classification } \\
\hline & & Special-use & Protection & Production \\
\hline Total area & 12306 & 1920 & 5920 & 4465 \\
\hline A. Natural Forest & 10088 & 1837 & 5106 & 3145 \\
\hline 1. Timber forest & 7926 & 1456 & 3977 & 2493 \\
\hline 2. Bamboo forest & 799 & 82 & 343 & 373 \\
\hline 3. Mixed forest & 682 & 113.8 & 319 & 249 \\
\hline 4. Mangrove forest & 68 & 12.7 & 42 & 13 \\
\hline 5. Rocky mountain forest & 611 & 171 & 424 & 16 \\
\hline B. Plantation & 2218 & 83 & 814 & 1320 \\
\hline 1. Plantation with forest stock & 895 & & & \\
\hline 2. Plantation without forest stock & 1046 & & & \\
\hline 3. Bamboo and Dendrocalamus & 81.4 & & & \\
\hline 4. Other tree plantations & 195.8 & & & \\
\hline
\end{tabular}

Source: MARD (2006)

In 2001, the government promulgated Decree 08/QD to regulate the management of these three forest types. The decree divides special-use forests into: (1) national parks; (2) natural reserves, further sub-divided into natural reserves and fauna and flora habitat reserves; and (3) historical, cultural and environmental relics or landscape-protected areas.

According to the draft National Forest Strategy 2020 (MARD 2006), the total area of land with forest cover is to be increased to 16.2 million ha, consisting of 5.7 million ha of protection forest, 2.3 million ha of special-use forest and 8.2 million ha of production forest. National forest cover is to be increased to $43 \%$ of the national 
territory, the same as was estimated for 1943 (see below). Compared to the 2004 forest cover, the area of special-use forests is to increase slightly; that of protection forests will remain the same, while the area of production forest is to be doubled.

\section{Changes in Forest Cover}

According to available data, in 1943 Vietnam had 14.3 million ha of natural forests, accounting for $43 \%$ of the country's area. Since that time, forest cover has decreased dramatically, especially during the 1976-1990 period. During that period, about 98,000 ha were annually contracted for logging (Table 5). Forest cover declined to $27.2 \%$ in 1990 , but increased again to $28 \%$ in 1995 , as a result of forest protection and rehabilitation programs (Figure 1). This changing trend, however, still meant that from 1991 onward the area of natural forests continued to decline, albeit at a slower pace than in previous years. The establishment of plantations increased fast. As a result, the total forest area first stabilized and then increased. As of 2004, the Vietnam's forest cover had reached 12.3 million ha, or $36.7 \%$ of the country's total area.

Table 5. Vietnam's forest cover throughout different periods [1000 ha]

\begin{tabular}{lrrrrrrrr}
\hline & $\mathbf{1 9 4 3}$ & $\mathbf{1 9 7 6}$ & $\mathbf{1 9 8 0}$ & $\mathbf{1 9 8 5}$ & $\mathbf{1 9 9 0}$ & $\mathbf{1 9 9 5}$ & $\mathbf{2 0 0 0}$ & $\mathbf{2 0 0 4}$ \\
\hline Total area & 14300 & 11169.3 & 10608.3 & 9891.9 & 9175.6 & 9302.2 & 10915.5 & 12306.7 \\
\hline Natural forest & & 11076.7 & 10016.0 & 9308.3 & 8430.7 & 8252.5 & 9444.1 & 10088.2 \\
\hline Plantation & & 92.6 & 422.3 & 583.3 & 744.9 & 1047.7 & 1471.3 & 2218.5 \\
\hline
\end{tabular}

Source: Data 1943-1995, the national M\&E Program for Changes in Forest Resources, FIPI (1995). Data 2000, the national forest inventory; data 2004 - MARD 2006.

The causes of forest cover decline between 1943 and 1990 are complicated and diverse, and somewhat debated. Many commentators agree on the following as the main causes:

- Land conversion for farm land. This includes conversion of forestland by independent swidden agriculturists and conversion for estate crop production. Vietnam's accelerated population growth during much of the second half of the $20^{\text {th }}$ century and its persistent poverty levels were factors that contributed to an accelerated need for agricultural land.

- Devastation by war, including two anti-invasion wars, from 1945-1954 and 1961- 1975. During these wars Vietnam lost nearly 2 million ha of forests.

- Forest fires.

- Fuelwood and timber over-harvesting by state organizations, but also illegal logging by individuals and units.

- Poor management capacity of the forestry sector and a deficient institutional and legal framework. 


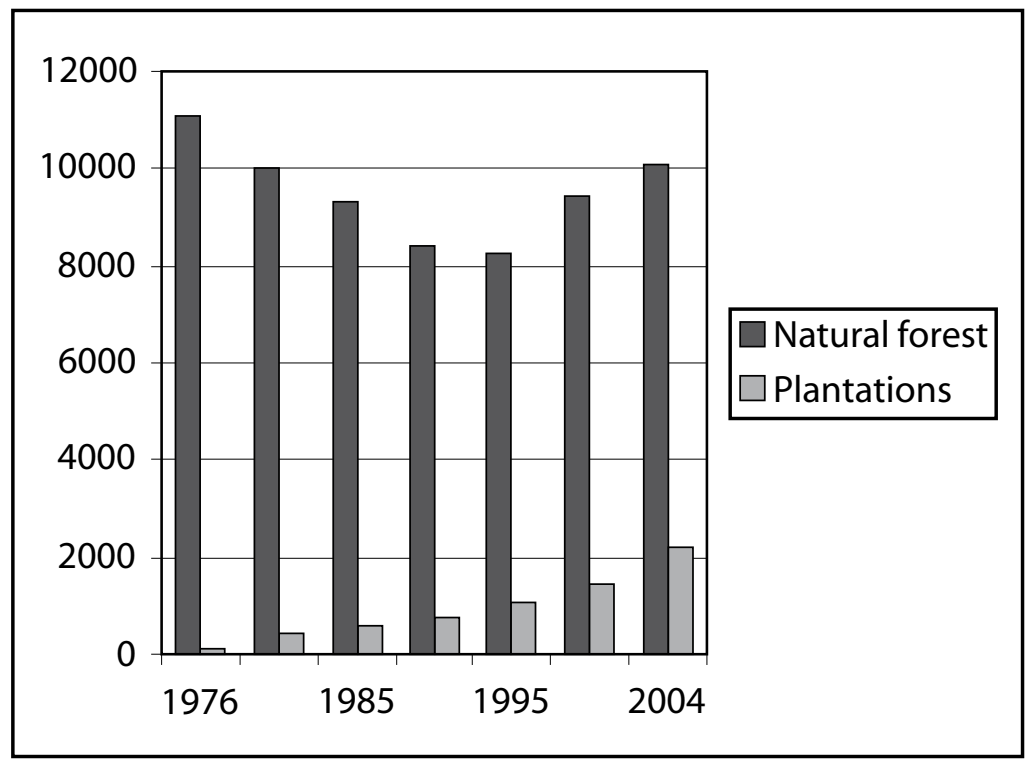

Figure 1. Changes in Vietnam's forest cover 1976-2004

Table 5 shows an increase in the total forest area after 1990. The forest area in 2004 had increased by 2,861 thousand ha $(31.18 \%)$ since 1990 . The increase comprised 1,549 thousand ha of natural forest (a $13.87 \%$ increase) and 1,312 thousand ha of plantations (a 163.5\% increase). There is little doubt that the quality of rehabilitated natural forests is much lower than the forest it replaced. The areas of rich, medium and poor quality natural forests are still declining, especially in the Central Highlands and Southeast regions. Poor quality natural forests, with a forest stock of less than $80 \mathrm{~m}^{3} /$ ha, were recently estimated to occupy up to $80 \%$ of the total forest area.

The growth of plantations has contributed significantly to Vietnam's forest cover. Table 6 represents the situation in the year 2000, and shows that plantations, especially industrial plantations, are unequally distributed among ecological zones.

Table 6. Commercial plantations by Region [1000 ha]

\begin{tabular}{lrrrr}
\hline Ecological zone & Acacia/Eucalyptus & Pine & Rubber & Total \\
\hline Northern Mountains & 228 & 78 & & 306 \\
\hline Red River Delta & 20 & & & 20 \\
\hline North Central & 114 & 91 & 5 & 210 \\
\hline South Central & 115 & & & 115 \\
\hline Eastern Highlands & 15 & 13 & 164 & 192 \\
\hline Southeast & 55 & 24 & 243 & 322 \\
\hline Mekong Delta & 29 & & & 29 \\
\hline Total & 576 & 206 & 412 & 1194 \\
\hline
\end{tabular}

Source: JPD (2001) 
Dominant forest tree species are acacia, eucalyptus, pine, bamboo and some indigenous species. The Mekong Delta has major plantations of indigenous species like Rhizophora apiculata and Melaleuca leucadendra. This region also has important rubber plantations as rubber wood is now an important raw material for the woodprocessing industry.

\section{Special-Use Forests}

An important part of Vietnam's forest rehabilitation has focused on protection and special-use forest areas. The report, therefore, provides a brief summary of these two forest types.

In 2006 Vietnam had an official list of 128 special-use forests that have a total planned forest cover of 2,225 thousand ha (Table 7). In 2006 the area designated for special-use forest had an estimated $81.34 \%$ of forest cover. The list includes 28 national parks with a total area of 966,127 ha; 62 natural reserves with the total area of $1,111,128$ ha (49 natural reserves $1,043,542$ ha; 13 fauna and flora habitat reserves $70,586 \mathrm{ha})$; and 38 landscape protected areas with the total area 147,894 ha.

Table 7. Vietnam's special-use forest status [ha]

\begin{tabular}{|c|c|c|c|c|c|}
\hline \multirow[b]{2}{*}{$\begin{array}{l}\text { Special-use } \\
\text { forest type }\end{array}$} & \multirow[b]{2}{*}{ Number } & \multirow{2}{*}{$\begin{array}{r}\text { Total } \\
\text { assigned } \\
\text { area }\end{array}$} & \multicolumn{3}{|c|}{ Status in 2006} \\
\hline & & & $\begin{array}{r}\text { With forest } \\
\text { cover }\end{array}$ & $\begin{array}{r}\text { Without } \\
\text { forest cover }\end{array}$ & $\begin{array}{r}\text { Percentage } \\
\%\end{array}$ \\
\hline National Park & 28 & 966127 & 861260 & 104867 & 89.1 \\
\hline Natural Reserve & 62 & 1111128 & 851442 & 262686 & 76.6 \\
\hline $\begin{array}{l}\text { Landscape } \\
\text { protected area }\end{array}$ & 38 & 147894 & 97896 & 49998 & 66.0 \\
\hline Total & 128 & 2225149 & 1810598 & 630239 & 81.34 \\
\hline
\end{tabular}

Source: Forest Protection Department (2006)

\section{Land Targeted for Forest Rehabilitation}

The prime target for the establishment of much of the 3.9 million ha needed to meet the objective of achieving a nationwide forest cover of 16.2 million ha by the year 2020 is so-called unused land that has been allocated by the state to the forestry sector. Table 8 shows the areas of different types of unused land. The main target for forest rehabilitation is unused hilly land, which in 2003 covered 6,690 million ha. Unused hilly land is unevenly distributed among different regions, and is concentrated in the Northwest, Northeast, North Central, Central Coastal and Central Highland regions (Table 9). Commentators question the real status of Vietnam's unused land, as some of it is actually agricultural land under fallow. 
Table 8. Current status of unused land area in Vietnam, 2003 [ha]

\begin{tabular}{lr}
\hline Total unused land area & 8867412 \\
\hline Unused plain area & 471821 \\
\hline Unused hilly land area & 6690793 \\
\hline Land with unused water surface & 150594 \\
\hline Rivers and springs & 746879 \\
\hline Rocky mountains without trees & 590396 \\
\hline Other unused land areas & 216929 \\
\hline
\end{tabular}

Source: MONRE (2003)

Table 9. Current status of unused land area in Vietnam by region, 2003 [ha]

\begin{tabular}{lr}
\hline Regions & Area (ha) \\
\hline Total area & 6690793 \\
\hline $\begin{array}{l}\text { Northern Mountains region and Northern Central region (Northwest and } \\
\text { Northeast) }\end{array}$ & 3407550 \\
\hline Northern Central Plain & 24148 \\
\hline Northern Central Region & 1351468 \\
\hline Southern Central coastal region & 1195986 \\
\hline Central Highlands & 693456 \\
\hline Southeast region & 19730 \\
\hline Mekong Delta & 11618 \\
\hline
\end{tabular}

Source: MONRE (2003)

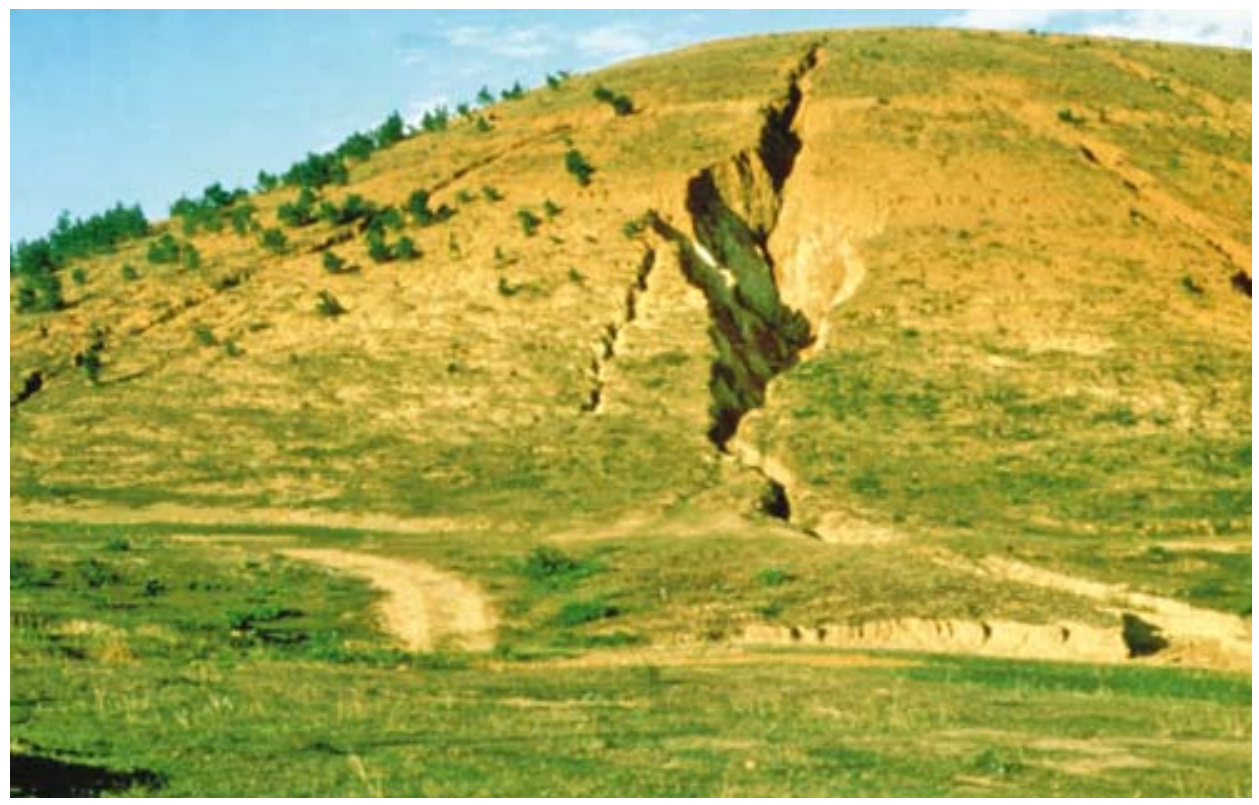

The final stage in land degradation. (Photo by Reidar Persson) 
Aiming to facilitate its conversion into forest land, the forest sector has classified the unused land with forestry potential (bare land and denuded hills) into three types (MARD 2004):

1a Poor land with grasses and shrubs: 2,150,662 ha.

1b Fairly fertile land with a 2-3 m tall vegetation, including scattered shrub or bamboo: 2,133,781 ha.

1.c Fertile land with $3 \mathrm{~m}$ tall vegetation, including regenerated timber trees: 2,054,530 ha.

Vietnam's forest rehabilitation philosophy holds that, apart from forest planting operations on bare land and denuded hills, it is also necessary to restore degraded natural forest areas in order to improve the protection value and the market value of forests (see Chapter One). The area of exhausted natural forest and rehabilitated young forest, with an area of 7,774,268 ha, is very large, and it includes nearly 3 million ha of newly-rehabilitated young forest (National Forest Inventory 1999).

\section{Forestry Economics}

\section{Vietnam's Dependence on its Forest Sector}

Forest restoration efforts aim to enhance the capacity not only of environmental protection but also of forestry-based economic development. Vietnam's dependency on its forest sector remains complicated and diversified. In order to understand Vietnam's forest dependency and its related planning it is necessary to clearly distinguish between the forestry benefits that are currently captured, and anticipated future forestry benefits.

An estimated 25 million Vietnamese people are living in or near forests and depend for some part of their subsistence on forest resources (GoV 2005). According to official statistics, Vietnam's forest-dependent people depend on forest resources for an average $20 \%$ of their total (monetary and non-monetary) income (GoV 2005). Although it is difficult to verify these figures, some detailed studies do corroborate them. Raintree and colleagues (1999) calculate a 15\% figure, while Mai and colleagues (1999; quoted in Sunderlin and Huynh 2004:33) find a 24\% figure in a different study. Fuelwood, bamboo shoots, rattan, wildlife and tobacco are the forest products most widely harvested by local people (Sunderlin and Huynh 2004). According to 2001 statistics on farm household living standards collected by the General Statistics Office (GSO), the share of people's incomes from forestry activities is highest in mountainous areas with high poverty rates (Table 10).

Fuelwood remains a vital forest product for Vietnam's rural population since it supplies between 7\% (GoV 2005) and 20-25\% (Castrén 1999) of the country's energy supply. It remains without a doubt the principal energy source of the majority of people living in remote rural forest regions. The estimated annual fuelwood consumption was 36 million $\mathrm{m}^{3}$ in 1992 (Castrén 1999). In-depth studies suggest that these estimates are no exaggeration. In Ke Go National Reserve, fuelwood consumption was calculated to be $2.3 \mathrm{~kg} /$ person/day. This figure doubled in the 
buffer zones of Ba Be National Park (McElwee 2001). If the Ke Go figure is used as an average, the 25 million people living in or near forests would annually consume a volume of fuelwood that is similar to the volume estimated by Castrén (1999). This does not take into consideration the fact that not only forest-dependent people but others, too, consume fuelwood for various purposes.

Table 10. Household incomes from agriculture, forestry and fisheries [\%]

\begin{tabular}{lrrr}
\hline Region & $\begin{array}{r}\text { Income from } \\
\text { agriculture }\end{array}$ & $\begin{array}{r}\text { Income from } \\
\text { forestry }\end{array}$ & $\begin{array}{r}\text { Income from } \\
\text { fisheries }\end{array}$ \\
\hline Total area & 79.9 & 4.8 & 15.3 \\
\hline Northwest & 73.7 & 23.0 & 3.3 \\
\hline Northeast & 82.3 & 11.7 & 6.0 \\
\hline Red River Delta & 94.1 & 0.2 & 5.7 \\
\hline Northern Central & 77.1 & 7.2 & 15.7 \\
\hline Southeast Central & 59.0 & 5.2 & 35.8 \\
\hline Highland & 90.6 & 7.4 & 2.0 \\
\hline Southeast region & 82.2 & 2.0 & 15.2 \\
\hline Mekong Delta & 75.9 & 2.1 & 22.0 \\
\hline
\end{tabular}

Source: Nguyen S. C. (2003)

The National Forest Product Processing Department (2004, cited in GoV 2005) provides estimates of forest product exports, as presented in Table 11. During 20012003 about 3 million $\mathrm{m}^{3}$ of timber, 500,000 tons of bamboo and 20,000 tons of NTFPs were harvested from Vietnam's forests. Vietnam's biodiversity action plan estimates that agricultural, forest and marine products obtained from Vietnam's biodiversity contributed some USD 2 billion to Vietnam's economy (Clarke n.d.). The data from Table 11, which only reflects the officially recognized export value, suggests that this figure was much higher in 2005.

Table 11. Vietnam forest product exports 1996-2005 [million USD]

\begin{tabular}{lrrrrrrrrrr}
\hline Category & $\mathbf{1 9 9 6}$ & $\mathbf{1 9 9 7}$ & $\mathbf{1 9 9 8}$ & $\mathbf{1 9 9 9}$ & $\mathbf{2 0 0 0}$ & $\mathbf{2 0 0 1}$ & $\mathbf{2 0 0 2}$ & $\mathbf{2 0 0 3}$ & $\mathbf{2 0 0 4}$ & $\mathbf{2 0 0 5}$ \\
\hline Timber & 61 & - & 108 & - & 219 & 334 & 435 & 567 & 1,054 & 1,500 \\
\hline NTFPs & & & & 78.4 & 98.3 & 108.3 & 138.6 & 154.7 & 198.1 & 200 \\
\hline Total & & & & & 317.3 & 442.3 & 573.6 & 721.7 & $1,252.1$ & 1,700 \\
\hline
\end{tabular}

Source: GSO, Customs General Department

The share of the forest sector was officially estimated at 1\% of GDP (GoV 2005). This figure does not include the contribution of the industrial production sector, unrecorded forest product consumption or environmental services (Sikor 1998). 
Estimated that the forest sector contributed $2 \%$ of total national revenue and $10 \%$ of the total national export value for the period 1986-1989. Castrén (1999) estimated that the forest sector contributed $6 \%$ of the national industrial production sector.

Different authors have claimed different figures for the human resources of the forest sector. Sikor (1998) stated that the forest sector had about 1.2 million people (4\% of the national labour force in Vietnam); however, many of them worked parttime (Sikor 1998). As reported by Castrén (1999), the figure is less than $1 \%$ but it does not take into account the number of people working for the processing industry. The labour force working in wood-processing enterprises, carpentry and traditional handicraft and NTFP processing numbered approximately 1 million people in 2003.

\section{Wood Pulp, Paper and other Wood Processing Industries}

The supply of raw material for the wood pulp and paper industry is a key defining factor in forest plantation planning. The wood for this industry currently comes from both natural forests and plantations, but increasingly is shifting to plantations. In 2000, 1.6 million $\mathrm{m}^{3}$ of plantation wood went to industrial production (JPD 2001). The national paper and pulp industries required about $300,000 \mathrm{~m}^{3} /$ year. Timber from plantations is also used for manufacturing particle boards and MDF. In 2003, Vietnam consumed 80,000 tons of particle board and 40,000 tons of MDF. That year the production of particle board and MDF was, respectively, $60,000 \mathrm{~m}^{3}$ and $30,000 \mathrm{~m}^{3}$; the difference came from imports. In 2004, 1,440 thousand $\mathrm{m}^{3}$ timber was consumed and 800,000 tons of dry particle board was produced by the sector. During 2004 and 2005 many new particle board factories were established near sea ports from the south to the north.

Vietnam's national demand for saw logs was about 2.2 million $\mathrm{m}^{3}$ in 2003 . The value of imported raw timber in 2004 was around USD 350 million. The raw material supplies stem from natural forests, plantations, including rubber plantations, pine forests and imports. The importance of plantation timber is increasing. In 2000, for instance, $390,000 \mathrm{~m}^{3}$ of saw logs came from plantations, including $190,000 \mathrm{~m}^{3}$ of rubber wood. Plantations mainly provide supplies of small timber (JPD 2001). The mining sector consumed about $60,000 \mathrm{~m}^{3}$ of pit wood. These figures however, do not consider the considerable proportion of Vietnam's round timber supply that is illegal (GoV 2005).

\section{Future Demands for Timber and NTFPs}

Vietnam's population is estimated to grow to 100 million by 2020 and the economy has shown a constant high growth rate of $7 \% /$ year over recent years. This growth rate is expected to increase, rather than decline, over the next few years. By 2020 Vietnam is expected to have become an industrial country, and demand for timber and NTFPs will concurrently increase. Forecasts of forest product consumption have been included in the National Forest Strategy for the period 2006-2020 (MARD 2006) and are summarized in Tables 12-14. 
Table 12. Forecast of Vietnam's saw log and wood-based panel consumption [1000 $\mathrm{m}^{3}$ ]

\begin{tabular}{lrrrrr}
\hline Products & $\mathbf{2 0 0 3}$ & $\mathbf{2 0 1 0}$ & $\mathbf{2 0 1 5}$ & $\mathbf{2 0 2 0}$ & Annual growth (\%) \\
\hline Sawn logs & 2211.0 & 3588.9 & 5009.5 & 6991.5 & 7 \\
\hline MDF & 40.1 & 79.6 & 117.4 & 166.4 & $7-8$ \\
\hline Particle Board & 80.0 & 147.6 & 215.5 & 312.5 & $8-9$ \\
\hline Wood-based panel & 11.0 & 18.3 & 26.1 & 37.2 & $7-9$ \\
\hline
\end{tabular}

Source: MARD (2006)

Table 13. Vietnam's forecasted paper consumption [1,000 tons]

\begin{tabular}{lrrrrr}
\hline Products & $\mathbf{2 0 0 3}$ & $\mathbf{2 0 1 0}$ & $\mathbf{2 0 1 5}$ & $\mathbf{2 0 2 0}$ & Annual growth (\%) \\
\hline Newspaper & 54.8 & 92.8 & 133.4 & 192.0 & $8-9$ \\
\hline Writing paper & 159.9 & 295.2 & 451.0 & 690.6 & $9-11$ \\
\hline Card board & 680.1 & 1240.9 & 1880.9 & 2856.4 & $9-11$ \\
\hline Others & 75.8 & 138.3 & 209.6 & 318.4 & $9-11$ \\
\hline Total & 970.6 & 1767.2 & 2674.9 & 4057.4 & $9-11$ \\
\hline
\end{tabular}

Source: MARD (2006)

Table 14. Forecasted timber and forest product demands 2006-2020

\begin{tabular}{lrrrr}
\hline & $\mathbf{2 0 0 3}$ & $\mathbf{2 0 1 0}$ & $\mathbf{2 0 1 5}$ & $\mathbf{2 0 2 0}$ \\
\hline $\begin{array}{l}\text { Timber: domestic consumption and export } \\
{[1000 \text { m3] }}\end{array}$ & 7420 & 14004 & 18620 & 22160 \\
\hline $\begin{array}{l}\text { Large timber used for industrial and civil } \\
\text { industries }\end{array}$ & 4561 & 8030 & 10266 & 11993 \\
\hline $\begin{array}{l}\text { Small wood used for producing particle } \\
\text { board and wood-based panels }\end{array}$ & 1649 & 2464 & 2992 & 1682 \\
\hline $\begin{array}{l}\text { Pulpwood } \\
\text { Pitwood }\end{array}$ & 1150 & 3388 & 5271 & 8283 \\
\hline $\begin{array}{l}\text { Export value of timber products and NTFPs } \\
\text { [million USD] }\end{array}$ & 721 & 2400 & 3200 & 4000 \\
\hline Wood products & 567 & 2100 & 2600 & 3200 \\
\hline NTFPs & 154 & 300 & 600 & 800 \\
\hline
\end{tabular}

Source: MARD (2006)

Comparing the forecasted forest product consumption with current stocks and the extrapolated supply from Vietnam's current natural forest and plantations suggests a substantial future deficit. This deficit will partly be covered through imports, but will also be covered from the expected expansion of production forests. This production forest expansion is expected to raise the supply of both large and small diameter 
timber. The area of production plantations is estimated to increase to between 2.32.6 million ha by the year 2015, or twice the area today, and eventually to reach 4 million ha.

\section{Environment Services and Tourism}

Because of its geography, Vietnam is particularly prone to natural calamities and therefore needs to pay much attention to environmental protection, especially of coastal regions and watershed. Floods, storms, droughts, soil erosion and saltwater intrusion are frequent events in Vietnam. The objective of the early country-wide efforts on forest restoration was to reverse the adverse impacts of forest logging on the fertile Red River and Mekong deltas. Annual economic losses caused by natural disasters were around USD 19 million in the 1980s and USD 200 million during the 1990s. Floods in October and November 1999, for instance, killed 600 people and caused an estimated USD 265 million worth of damage in central provinces. The same region suffered a severe drought the following year (ICEM 2003). A report by MARD (2001:7) states that 'Environmental protection is now the most important function of forests, especially to mitigate natural disasters'. The link between forest cover and downstream flooding is questioned by some FAO (2005).

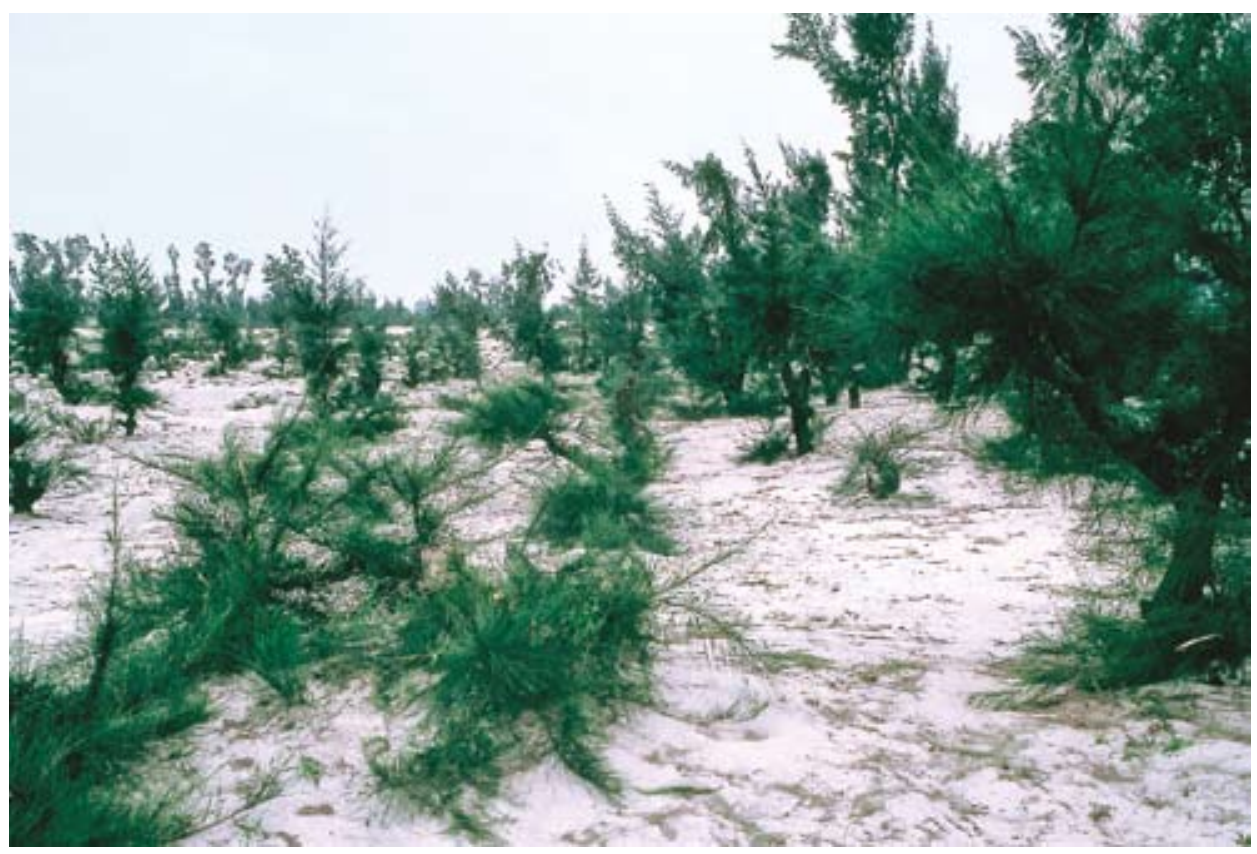

Twenty three km north of Bo Trach Old plantations of Casuarina equisetifolia, damaged by local population Vietnam. (Photo by Christian Cossalter)

Vietnam's hydropower capacity can supply $53 \%$ of the country's total energy need of 8,750 MW. The two main hydropower plants, Hoa Binh and Da River, located 
in the northwest ecological zone, can together supply 1,920 MW, and the Yaly plant in Gia Lai province in the eastern mountainous area has a capacity of $720 \mathrm{MW}$. Both the Hoa Binh and Yaly basins depend on water supply from regions with large proportions of bare lands (Table 9). They are the largest dam systems of the total 14 hydropower dams existing in 2003. In 2003, Electricity of Vietnam announced that it would build an additional eight dams. Severe droughts in 2005, however, drastically reduced the electricity supplied from hydropower that year (Planet Ark 2005). It is, therefore, of serious concern to the country how forest cover, or the lack thereof, influences the water flows of hydropower plants. An important function of Vietnam's special-use and protection forests is to mitigate soil erosion of lakes/ reservoirs and ensure stable water sources.

Vietnam has a developing tourism sector that is much dependent on its natural riches, and in particular the natural reserves and other special-use forests. From 1995 to 2000, the number of domestic tourists doubled to 10 million. In 2001, about 2.3 million foreign tourists came to Vietnam; about half of them were from China and Taiwan. Many forest officials are specifically considering tourist services for the national parks under their responsibility. Tam Da national park, located two hours travelling from Hanoi attracted about 50,000 domestic tourists and 3,000 international tourists in 1999 (GTZ 2,000, quoted by ICEM 2003).

According to the National Forest Strategy 2006-2020, the total value of forest environmental services by 2010 is estimated at USD 250 million, increasing to USD 2,000 million by 2020 .

\section{Institutions and Policies Related to Forest Restoration in Vietnam}

Forest policies, other relevant policies, legislation agencies and policy enforcement bodies are major factors that influence forest restoration in Vietnam. This section briefly presents the major aspects of Vietnam's forestry policy. First, the section introduces the organizational structure of the forest sector administration. Next, it describes the State Forest Enterprises (SFE) that have been playing a vital role in Vietnam's forest sector, including forest rehabilitation projects. This is followed by an overall picture of Vietnam's forest policies and other relevant policies. Special attention is given to policies on land allocation, forest ownership transfer and forestation.

\section{Organizational Structure of Vietnam's Forest Sector}

The organizational structure of Vietnam's forest sector administration has four administrative levels: the central/national level, provincial level, district level and commune level. At present, Vietnam has 64 provinces, about 600 districts and 10,000 communes. All administrative levels are under the control of the state. Hamlets are under the jurisdiction of communes, but they are not a state administrative level. They function, however, as autonomous organizations, combining several communities in a single hamlet. Heads of hamlets are selected by the local people and are recognized 
by commune authorities. Hamlet heads act as people's representatives and contact persons for the commune authorities to communicate with local people. In some remote and isolated areas with ethnic minorities, heads of hamlets function together with village patriarchs who act as customary leaders. At the central level, MARD is responsible for forest sector administration, including special-use and protection forest management. The Forestry Department and Forest Protection Department are MARD's agencies tasked with forest administration. Two additional agencies, the Agro-forest Product Processing Department and the Rural Industry Department, are in charge of the forest product processing sector. Additional public service agencies involved in the forest sector are the Forest Inventory and Planning Institute (FIPI) and the Forest Science Institute of Vietnam (FSIV). The Forestry University and the Forestry Extension Division are attached to the Agriculture Extension Department.

At the provincial level, two forest administration agencies are under the control of the Provincial People's Committee (PPC). The first of these is the Department of Agriculture and Rural Development (DARD), in which the Forestry Sub-Department operates as a specialized agency to assist the Director of DARD in forestry activities. At present, Vietnam has 34 Forestry Sub-Departments with a total 530 employees. The second is the Forest Protection Sub-Department (FPsD), which serves to advise the province about forest protection. It can also enforce the Forest Protection and Development Law. Presently, there are 59 FPsD with a total of 1,300 employees.

At the district level, the Economics Division on Agriculture and Rural Development is under the control of the District People's Committee (DPC) and employs one or two forestry staff responsible for monitoring forestry activities. A Forest Protection Unit (attached to FPsD) operates in a certain districts. Vietnam presently has 424 Forest Protection Units with a total of 3,500 employees.

At the commune level, as regulated by the Forest Protection and Development Law, communes with forest cover are obliged to recruit forest employees. However, because of budget constraints, most communes have so far failed to employ any commune forest staff. Where they operate, Forest Protection Units assign one forest ranger to work in one commune/commune group.

Forestry extension in Vietnam is part of the provincial and district agriculture extension agency. The number of forestry extension workers, however, is very low and they cannot address the needs of all districts separately. Apart from the state forestry extension system, SFEs and non-state forestry enterprises and forestation projects funded by international donors have, in practice, provided most forestry extension services. In terms of quality, these services exceed the services offered by state forestry extension organizations. Voluntary forestry extension organizations at the local level have gradually been set up under the control of social and professional associations.

Within the framework of such large scale forestry projects as Program 327 and the 5 Million Ha Reforestation Project (5MHRP—see Chapter Three), the government has established Project Steering Committees to provide instruction on the implementation of programs or projects, with relevant sectors and ministries participating as members. There are also provincial Project Management Boards. 
MARD has also entrusted the Forest Protection Department, on behalf of the state, with the administration of special-use forests (national parks and nature reserves). Some big national parks are directly controlled by MARD while some special-use forests are managed by PPCs. In addition, some districts have been assigned to manage national parks and natural reserves. Unanimously accepted and clear criteria for the decentralization of special-use forest management at all levels do not yet exist, causing difficulties in establishing and managing national parks and natural reserves.

\section{State Forest Enterprises}

Before the 1990s, Vietnam's economy operated under a central planning mechanism. Under this mechanism SFEs were production units that specialized in forestry activities including forest harvesting, forest product processing, forest planting operations and forest rehabilitation. SFEs were also assigned to provide public services to facilitate socio-economic development in mountainous areas, for instance promoting fixed cultivation as an alternative to swidden agriculture, resettlement and new economic zone development. Between 1961 and 1990, SFEs afforested 1.4 million ha of industrial plantations, accounting for $71.12 \%$ of the total national area of plantations. SFEs made due contributions to national socio-economic development and national defence and security in mountainous areas.

Since Vietnam has shifted to a market-oriented economy, the state has stopped allocating funds to SFEs and even did not provide financial support for afforestation efforts. Instead, the state extended credit to SFEs, which were expected to self-finance their activities. Many SFEs failed to adapt to this new economic mechanism. In 1998, there were 405 SFEs, but this number has now decreased to 368. Forty of these are managed by the central government (Forestry Corporations and Paper Corporations), while 328 SFEs are managed by provincial governments. The total area of forests and natural land allocated to SFEs was 4.9 million ha. This included 4.4 million ha of forestry land, 3.0 million ha of which was natural forest, 536 thousand ha of plantations and 908 thousand ha of land without forest cover. The total estimated timber stock was 303.2 million $\mathrm{m}^{3}$ (including 287.4 million $\mathrm{m}^{3}$ in the natural forest and 13.8 million $\mathrm{m}^{3}$ in the plantations) and 2.8 million bamboo stems.

On average, one SFE manages 13,502 ha of forest land. However, these averages vary from 5,527 ha in the Northern Mountains and Midlands, to 15,100 ha in the Northern Central region, 18,437 ha in the Southern Central coastal region and 19,785 ha in the Central Highlands. As of 2000, SFEs had a total area of 125,369 ha of forestry land that was granted land use right certificates, or $25.2 \%$ of the total land under their control. Almost half of the SFEs suffered from land encroachment by local households and spontaneous immigrants.

The majority of SFEs have failed to manage the natural forest under their control in a sustainable manner, among other reasons due to excessive logging. They are, therefore, an important contributor to the serious decline of Vietnam's tropical forests. The number of SFEs with natural forests eligible for harvesting operations decreased to only 137 from 2001-2005. Many SFEs could only survive by participating in the nationwide forest rehabilitation programs 327 and 661 (see Chapter Three). As 
such, they stopped being production and business units, except for a few SFEs that were granted loans by the state for planting forests for wood pulp and pit wood production. SFEs' annual allowable cut from natural forests declined from 700,000 $\mathrm{m}^{3} /$ year in 1997 to 300,000-150,000 $\mathrm{m}^{3} /$ year for the period 2001-2005, for those companies that still had forest with timber stocks.

In general, SFE conditions have severely weakened sinceVietnam's economic reform era began. They have exhausted their forest resources, depleted capital resources and degraded their technical infrastructure. This has resulted in a low value of production per unit area of forest and poor and unstable living standards for the companies' workers. In response to this critical situation, the 1999 Government Decision 187, on the Renovation of the Organizational Structure and SFE Management Mechanism, declared that only SFEs that can operate their own production and business activities are allowed to be issued land use right certificates and design their own production and business activities.

In addition, the government promulgated Decree 200/2004/ND-CP on the renovation and development of SFEs, a decree that was affirmed by the Politburo's Resolution 28-ND/TW in 2003. SFEs are to be restructured into two types: (1) SFEs that conduct production and business activities and self-finance their operation through market mechanisms will be developed into Forestry Corporations; (2) SFEs that carry out public services are to be converted into Forest Management Boards, but these units will also operate as profit-making public service agencies. The decree also imposed a series of specific policies related to land, forest management and use, assets and finances, labour and science and technology in an attempt to guide the reformed forestry enterprises to better control their production and business activities.

Following this reform, some SFEs have become Protection Forest Management Boards, financed by the government for their forest planting and forest protection operations (ICEM 2003). Over recent years, the land area and personnel of some SFEs have been merged into protected areas_-Phong Dien Natural Reserve and Yok Don National Park, for example. In addition, great efforts are being made to merge three additional SFEs into the Tri An Natural Reserve; approval is pending (ICEM 2003).

At present SFEs still manage a fairly large area of forest land, despite their planned restructuring. Most of their land area is to be allocated for forest protection and afforestation (see below).

\section{Forest and Other Relevant Policies}

The Government of Vietnam has given high priority to forest rehabilitation, as stipulated by a series of laws and legal documents. The two national large-scale forestation programs, namely Program 327 and 5MHRP, will be discussed in detail in Chapter Three. However, some other policies, summarized in Table 15, have also impacted Vietnam's forest rehabilitation activities. Vietnam first formally expressed its commitment to forest rehabilitation in the 1984 National Conservation Strategy. The strategy aims, among other things, to increase national forest cover, improve soils, protect water resources and control floods. This commitment reflects an awareness of 
how watershed forest losses threaten economic development in the plain and coastal areas (Poffenberger and Nguyen H.P. 1998).

After the completion of Program 327, which lasted from 1993 until 1998, the area of land that had been afforested and rehabilitated increased remarkably. Program 327 was followed by the 5MHRP (1998-2010), which had the objective of rehabilitating 5 million ha of forests and protecting existing forests, in order to increase forest cover to $43 \%$. The 5MHRP entails (1) afforesting 2 million ha of protection and specialuse forests (afforest 1 million ha and regenerate 1 million ha); and (2) afforesting 3 million ha of production forests and utilizing land for dispersed tree planting. Aiming to fulfil the aforementioned tasks, the government's Decision 661 (1998) prescribed a synchronous policy system for crop structure, land, investment, credits, beneficiaries and product consumption, science and technology and international cooperation and foreign investment.

\section{Forest Land Allocation}

Forest and forest land allocation policies have been implemented in Vietnam since 1983 (through Decision No.184 from that year) and strengthened after the promulgation of the 1993 Land Law (Decree No.02/CP on forest land allocation). The revised Land Law of 2003 clearly defined the rights of land users in terms of land use, transfer, concession, lease, mortgage and contribution of capital on the basis of land value. The law stipulates the forest land allocation area at 30 ha, to be held for a period of 50 years. Households and individuals are allocated production and protection forest. The state also leases forest and forest land to other economic sectors for business and production objectives. The current state of allocated and leased forest land is presented in Table 16.

Table 16 suggests that:

- Forested land allocated to non-state economic actors amounts to 3.7 million ha, or $30.32 \%$ of the total forest land in the whole country. It also includes around 1 million ha of barren land and denuded hills, which were mostly allocated to households, amounting to $15 \%$ of the total barren land that is to be used for forestry purposes. This is slightly higher than the 0.9 million ha of barren land managed by SFEs.

- To date, the total area of allocated forest land (forested and non-forested) comprises only $23.2 \%$ of Vietnam's total forest land area planned for 2020. In practice, households are mainly allocated production forest land. The amount that has been allocated to households is $46.2 \%$ of the area planned for production forest in the whole country.

The above data warrant the conclusion that forest devolution in Vietnam is rather slow, and mostly poor quality forest is allocated. One reason for the slow progress has been the reassignment of forest land allocation responsibilities from MARD to MONRE. MONRE so far lacks both human and financial resources for this task.

A further constraining factor is that communities are hesitant to receive allocated forest land because of the strict conditions that come with allocation. Forest use rights are often more limited than before allocation (Sikor 2001). Particularly in remote and 
Table 15. National policies affecting forest rehabilitation in Vietnam (1991-2006)

\begin{tabular}{|c|c|}
\hline Policy area & Major policies \\
\hline \multirow{2}{*}{$\begin{array}{l}\text { Forest } \\
\text { management }\end{array}$} & - $\quad$ Forest Protection and Development Law 1991, 2004 \\
\hline & $\begin{array}{l}\text { Decision 08/2001/Q\$-TTg - Regulates the management of special-use } \\
\text { forests, protection forests and natural production forests }\end{array}$ \\
\hline \multirow{7}{*}{$\begin{array}{l}\text { Land policies; } \\
\text { beneficiary } \\
\text { policies }\end{array}$} & - $\quad$ Land Law 1993 \\
\hline & - $\quad$ Land Law 1998 (revised) \\
\hline & - $\quad$ Land Law 2003 (revised) \\
\hline & $\begin{array}{l}\text { - Decree } 01 / C P / 1995 \text { regarding land allocation for farming cultivation, } \\
\text { forest production and aquaculture by state owned enterprises }\end{array}$ \\
\hline & $\begin{array}{l}\text { Decree No. } 02 / C P \text { dated } 15 / 1 / 1994 \text { - Regulates forest land allocation } \\
\text { to organizations, households and individuals for sustainable and long- } \\
\text { term use }\end{array}$ \\
\hline & $\begin{array}{l}\text { Decree No.163/1999 dated 16/11/1999 - On forest land allocation, } \\
\text { lease and lending to organizations, households and individuals for } \\
\text { sustainable and long-term use }\end{array}$ \\
\hline & $\begin{array}{l}\text { Decision } 178 / 2001 / \text { - On the beneficiary rights and obligations of } \\
\text { households and individuals who have forests and forest land allocated, } \\
\text { leased and lent }\end{array}$ \\
\hline \multirow{12}{*}{$\begin{array}{l}\text { Tax, } \\
\text { investment, } \\
\text { credits }\end{array}$} & - $\quad$ Law on Agricultural Land Use Tax, 1993 \\
\hline & $\begin{array}{l}\text { Decree No. 129/2003/N§-CP- Regulates the enforcement of the } \\
\text { National Assembly Resolution on reduction and exemption of } \\
\text { agricultural land use tax. }\end{array}$ \\
\hline & - Domestic Investment Incentive Law, 1994. \\
\hline & - $\quad$ Investment Incentive Law (revised), 1998 \\
\hline & - $\quad$ Foreign Investment Law in Vietnam, 1996 \\
\hline & $\begin{array}{l}\text { - Decision 264-CT (22/7/1992) - On investment incentive policies for } \\
\text { forest development }\end{array}$ \\
\hline & $\begin{array}{l}\text { Decision 327/CT (15/9/1992) - On policies on the use of bare land and } \\
\text { denuded hills, coastal alluvial areas and water surfaces }\end{array}$ \\
\hline & $\begin{array}{l}\text { Decision 661/Q§-TTg (29/7/1998) - On objectives, duties, policies and } \\
\text { implementing organizations of the 5MHRP }\end{array}$ \\
\hline & - Resolution 03/2000 NQ-CP - On farm economy \\
\hline & $\begin{array}{l}\text { - Decision 187/1999/QQ§-CP - On the renovation of SFE organizational } \\
\text { structure and management mechanisms }\end{array}$ \\
\hline & $\begin{array}{l}\text { Resolution } 28 \mathrm{NQ} / \mathrm{TW}(16 / 6 / 2003) \text { on the further renovation and } \\
\text { development of farms and SFEs }\end{array}$ \\
\hline & $\begin{array}{l}\text { - Decision 160/1998 - Approving the master plan for the development } \\
\text { of the paper industry by the year } 2010\end{array}$ \\
\hline
\end{tabular}

isolated areas, local people rely on swidden cultivation as their main source of food, and may not be interested forest land that restricts agricultural production (Sikor 1998). 
Table 16. Forest land allocated and leased to households and foreign and joint venture companies $[2003$, ha]

\begin{tabular}{lrrr}
\hline Land categories & Total & $\begin{array}{r}\text { Households, } \\
\text { individuals }\end{array}$ & $\begin{array}{r}\text { Foreign and joint } \\
\text { venture companies }\end{array}$ \\
\hline Total & 3768783 & 3758518 & 10265 \\
\hline Forested land & 2723544 & 2715580 & 7964 \\
\hline Natural forest & 1718449 & 1718414 & 35 \\
\hline Plantation forest & 974681 & 966754 & 7929 \\
\hline Nursery gardens & 421 & 421 & 0 \\
\hline $\begin{array}{l}\text { Unused land (barren land and } \\
\text { denuded hills) }\end{array}$ & 1037275 & 1034974 & 2301 \\
\hline
\end{tabular}

Source: MONRE (2003)

\section{Forest Land Contracts (Decree No. 01/CP, 1994)}

As stated in Decision No. 187 (see Table 15), SFEs are required to allocate and contract forest land under their control to third parties for long-term use or protection, in accordance with Decree No.01 CP. In return, these third parties are entitled to specified benefits from the main forest products. With Decree No.200 (2004), it was decided that forestry companies can select the most efficient forest and forest land contracts in accordance with the existing regulations.

In practice, forest land allocated under long-term contracts accounts for only $31.2 \%$ of the land under control of the SFEs, while $53.69 \%$ has already been given out under annual contracts. The remaining area has been contracted out on periodical and work volume bases.

In the case of protection forest, priority is given to contracting households, especially those that are part of a resettlement group, poor, or live adjacent to forests. When accepting a forest protection contract, households sign annual contracts with their respective District Forest Protection Unit, a Program 661 Management Board or an SFE. Payment is per ha of land under contract (Sikor 2001). Legal regulations guiding contract implementation also allow long-term contracts (Nguyen T.Q. 2005). Regulations set the payment amount for the protection of 1 ha of contracted forest at 50,000 VND/year in 2005 (about USD 3), an amount widely considered to be too low. Per ha payments made under plantation contracts, however, are much higher. Sikor and Apel (1998) recorded such payments during the second half of the 1990 s at 1.7 million VND but contracted households spent about VND 700,000 to buy seedlings (Sikor and Apel 1998). Final payment depends on the number of surviving trees after one year. During the initial years, people can plant alternative crops together with the tree seedlings. Nguyen X.N. (2001) estimated that the VND 1.7 million payment only accounted for $60 \%$ of the total expenses of about USD $300 /$ ha. Reports suggest that tree plantation contracts are gaining popularity across country. However, Sikor (2001) suggests that plantation contracts are less effective in the location where he did his research. 


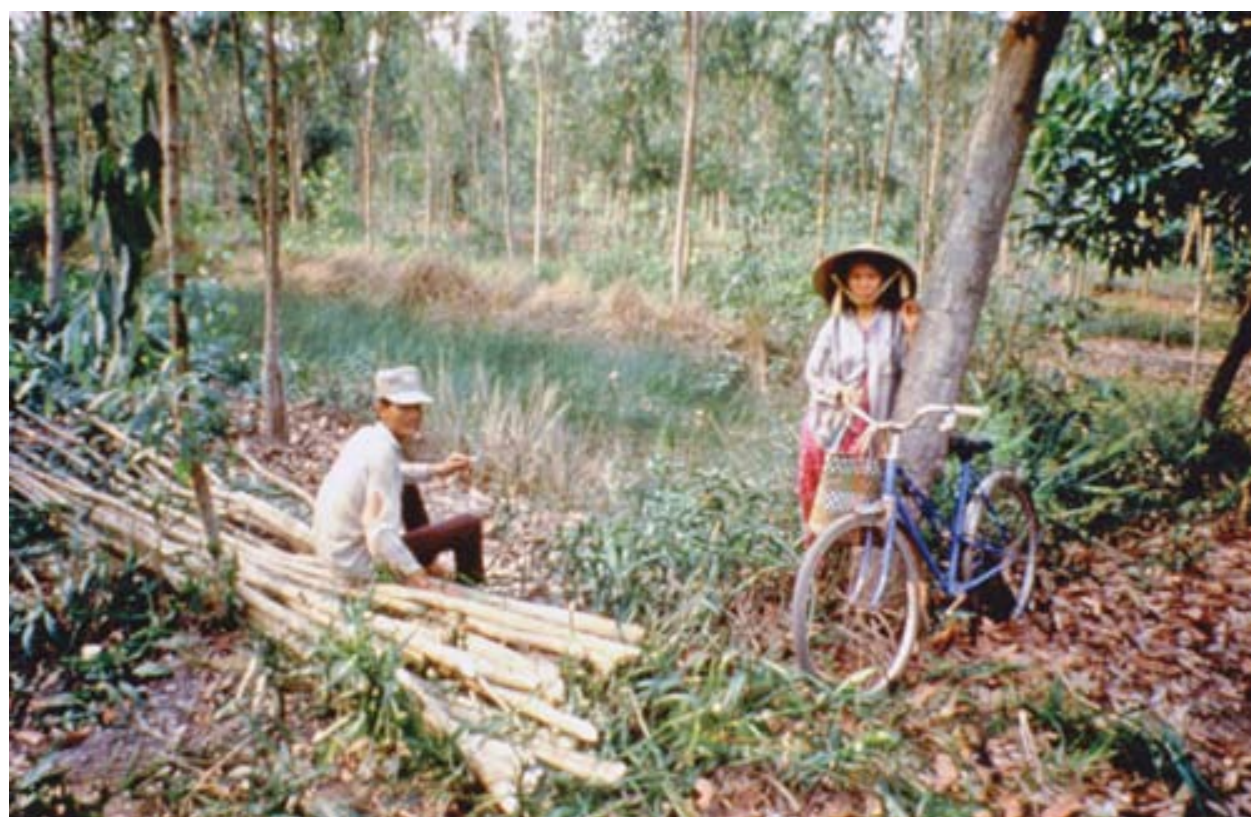

Villagers harvest poles in a woodlot of Acacia auriculiformis. (Photo by Neil Byron)

According to Sikor (1998) forest land allocation, forest protection contracts and benefit sharing only encouraged farm households in relatively high economic development regions to join rehabilitation programs, as people there can access timber markets. As a result, Vietnam's forest rehabilitation programs have contributed to the greening of denuded hills in the central region of Vietnam (Sikor and Apel 1998). Particularly in more remote locations, forest protection contracts have not significantly changed people's access to forest and forest resources within their own villages, as people continue to abide by customary practices. Reports suggest that households do prevent others from using allocated forest areas for grazing, timber exploitation and NTFP collection. However, there is some resistance to reporting violations.

\section{Investment and Credit Policies}

The state promulgated investment and credit policies, largely to support the 5MHRP. In this section we highlight five of them:

1. The state invested funds from its budget for the protection of protection and special-use forest in very critical areas. This covered the payment of protection contracts of up to 50,000ha/year, for a period of five years. Contracts for forest regeneration in combination with additional plantations amounted to VND 1 million/ha/year for a period of six years.

2. The state also provided resources for the plantation of crucial and very crucial protection forest. At the beginning of 5MHRP the amounts farmers received for these forests averaged VND 2.5 million/ha, but this has increased to VND 4 million/ha since 2004. Households and individuals who invested their own 
means in forest plantations of rare and valuable species with a 30-year growth cycle, were eligible to receive support of VND 2 million/ha.

3. The state invested in infrastructure, scientific research and forest extension serving projects and programs.

4. Organizations and individuals that engage in production forest plantation and regeneration can access preferential investment credit with an annual interest of $5.4 \% / y e a r$. In reality, however, many organizations and individuals could not benefit from this opportunity.

5. ODA is seen as an important capital source for forest rehabilitation: many afforestation projects successfully use ODA funds from WFP, SIDA, KFW and JBIC, among others. The total state and ODA investment in the 5MHRP between 1998 and 2005 amounted to VND 5,473.3 billion, or VND 781.9 billion/year (Table 17).

Table 17. 5MHRP investments [1998-2005; million VND]

\begin{tabular}{|c|c|c|}
\hline \multicolumn{2}{|c|}{ Capital source } & \multirow{2}{*}{\begin{tabular}{r|} 
Total \\
5473290
\end{tabular}} \\
\hline To & & \\
\hline 1. & State budget & 3317848 \\
\hline 2. & Local budget & 593952 \\
\hline 3. & Investment credit & 1190483 \\
\hline 4. & ODA & 371077 \\
\hline
\end{tabular}

Source: MARD (2005)

\section{Policies on Benefit Sharing and Tax Reductions}

During the early period of forest management contracts, rights to forest product exploitation were rather limited. Contracted households only had the right to collect a certain limited volume of dry firewood and NTFP, while using timber, cutting trees for firewood or converting forest for agricultural purposes were not permitted. This situation was meant to change with Decision of the Prime Minister No.178, issued in 2001. In crucial and very crucial protection forest, contracted households are entitled to exploit firewood, NTFP under canopy and pruned products.

In the case of production forests, when households invest their own means, they are granted plantation ownership and have the right to decide the forest plantation period and method. All products exploited from plantation forest, like bamboo, rattan and NTFP can be marketed freely. Selling wood from plantation forests is also allowed.

Organizations and individuals who replant fallow land and denuded hills are entitled to preferential tax in accordance with the Law on Investment Encouragement. When timber is sold from regenerated natural forest, the natural resource tax is not levied. When forest products are sold from plantation forest, the business tax is not levied. 
By the end of 2003, the National Assembly had promulgated a policy exempting and reducing agricultural land use tax for farmers engaging in forest rehabilitation. Households that establish forest plantations and own an allocated area of less than 30 ha are exempt from agricultural land use tax. Other economic organizations that manage forest plantations are entitled to a $50 \%$ tax reduction. This tax exemption and reduction has been applied since 2003 and will end by 2010. The policy has encouraged organizations, households and individuals to actively participate in the $5 \mathrm{MHRP}$, particularly in the plantation of 2 million ha of production forest. 



\section{Chapter 3}

\section{Histories of Forest Rehabilitation}

\section{Early Forest Rehabilitation Efforts}

Vietnam is known for its efforts to rehabilitate its forest cover, in addition to its drive to develop its forestry, and wood and non-wood forest product-based industries. The country's 5MHRP, which is being executed between 1998 and 2010, is the latest major undertaking at the national level to preserve and restore forest cover. However, major programs with similar objectives have been around for much longer. This chapter provides an overview of forest rehabilitation in Vietnam until today. The first part looks at forest rehabilitation prior to Program 327 and the 5MHRP. The report analyzes both programs in detail in the second half of this chapter.

Various authors locate the starting period of a serious plantation program in the mid-1950s (i.e. Lang 2002, Nguyen and Gilmour 1999). Since that time, reforestation activities have had multiple objectives, including sustaining rural livelihoods and promoting rural employment (Carew-Reid et al. 1999). The exact history of the country's forest rehabilitation efforts and the areas rehabilitated are not easy to trace, while sources of information contradict each other.

The Ministry of Forestry, which operated from 1976 until it was integrated with the Ministry of Agriculture and Rural Development in 1996 (Nguyen T.Q. 2005; Sikor 1998), carried out five national programs, including a national afforestation program and a forest protection program (Sikor 1998). ${ }^{7}$ The national afforestation program, implemented with national funds, achieved-according to Nguyen and Gilmour (1999) and Carew-Reid et al. (1999) - the establishment of 219,000 ha between 1955 and 1975 . The rate of rehabilitation, however, vastly increased over the subsequent 10 years, between 1975 and 1985, when over 1 million ha were planted. This pace of rehabilitation continued after 1985. Carew Reid (1999) cites

\footnotetext{
7 The other three programs were: the fixed cultivation and sedentarization program, the forest management and forest industries program, and the human resource development program, including research and extension.
} 
official figures of 563,120 ha for the same period, but poor survival rates. Sikor (1998) suggests that between 1961 and 1985, 1.4 million ha of plantation were established. According to Ministry of Forestry data, concentrated forest plantation area from 1961 to 2001 amounted to close to 4 million ha (Table 2a, b).

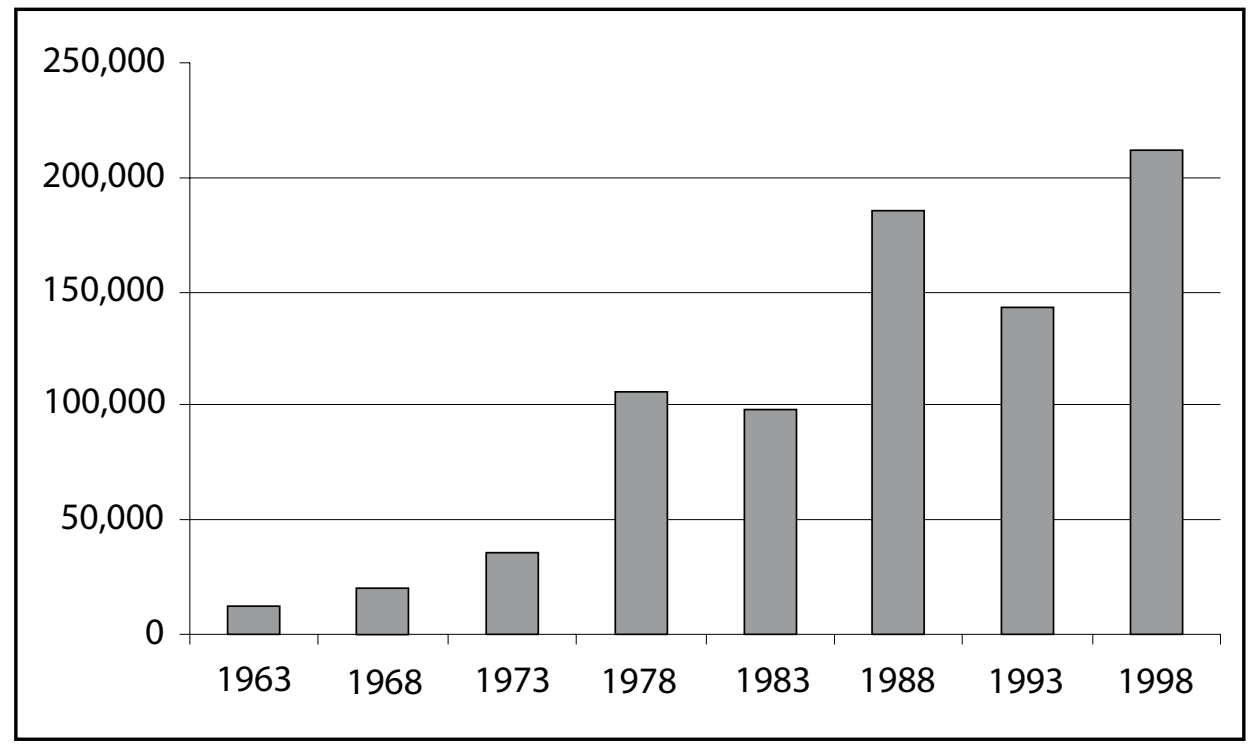

Figure 2a. Average annual forest plantation establishment for five-year intervals. Years along the $\mathrm{x}$-axis represent mid-year for each five-year period.

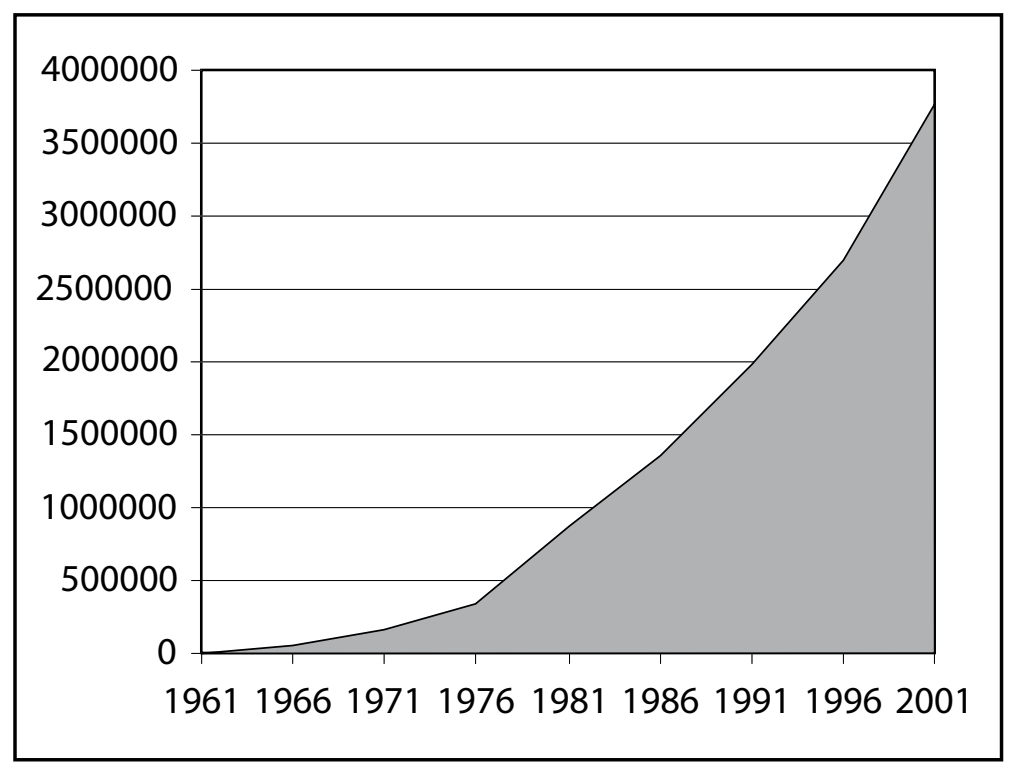

Figure 2.b. Accumulative plantation establishment 1961-2000 [ha]. Source MOF (1991) and MARD (2004) 
Figures $2 \mathrm{a}$ and $2 \mathrm{~b}$ provide data on the annual forest plantation area under forest plantation and accumulative plantation establishment since 1961. If the data in Figure 2 are correct, the accumulative total of forest plantations established between 1961 and 2001 is double the current forest plantation area (2004). This anomaly is probably the result of the following factors: in the early period, the main purpose of forest plantations was the greening of bare land and denuded hills, but these efforts suffered from low financial investment and limited plantation techniques with respect to, for example, adequate species selection and tending of plantations. As a result, survival rates and plantation establishment were low. Plantation locations were, as a consequence, frequently replanted. In addition, some plantations were reconverted for other uses, and forest fires destroyed established plantations.

\section{Scattered Tree Planting}

A significant contribution to Vietnam's forest rehabilitation is the scattered tree planting initiative. This initiative has its origin in the 1950s and was endorsed by Chairman Ho Chi Minh in 1959 as the Tet Tree Planting Festival. It has lead to an annual repetition of tree planting by people in all walks of life. Nguyen and Gilmour (1999) calculate that several billion trees have been planted since 1955 as part of this initiative, and 300-400 million trees annually since 1986. In total some 3.6 billion scattered trees were planted between 1960 and 1985, according to Sikor (1998). Castrén (1999) estimates that between 1 and 2 billion scattered trees have been planted in Vietnam, which he believes has been the equivalent of 1 to 2 million ha of forest plantation. A significant area, no matter what estimates are accepted.

\section{World for Food Program}

A second program that had great significance for Vietnam's forest rehabilitation early on is the World Food Program (WFP_often identified by the acronym PAM). The World Food Program started operating in Vietnam in 1975, and until the year 2000 invested a total of USD 500 million in the country. The Vietnam WFP encompassed a conglomerate of projects that included forestry, irrigation and primary health care. Do Dinh Sam et al. (2004) report that the forestry program under WFP started in 1975. In the various reviews that exist of international cooperation projects in Vietnam, the earliest reference to a WFP plantation project is 1986 (Carew-Reid et al. 1999). In 1995 WFP was the principal source of international funding for environmental projects as at that time it had 10 projects with a total investment of USD 143 million. Projects supported by other international agencies like ADB and WB only started in the mid-1990s.

Do Dinh Sam et al. (2004) calculate that WFP implemented six forestry projects, with an allocated budget of USD 160 million. These funds were allocated to supply food to rural communities, and provide equipment and materials for 450,000 ha of forest plantation, construct forest roads, organize fire protection teams, and improve forest extension services. The forestry projects carried out under the WFP program focused on the development of demonstration plots and agroforestry production on steep slopes. Farmers were given the opportunity to select their own crops and 
species to plant. The most important criterion was the market potential of the species planted (Do Dinh Sam et al. 2004). In addition to the financial assistance, the WFP program received considerable input from the GoV, as the latter allocated forest land to farmers to ensure that the projects supported household investment in farmers' own land.

Do Dinh Sam et al. (2004) hold that the forestry projects carried out under WFP had good results. Large areas of land have been planted to trees, jobs were created, livelihoods in communities improved, forest plantation and agroforestry techniques have been transferred, gender equity in forestry has been promoted, and local staff have been trained in the organization and management of forestry projects. Carew-Reid et al. 1999 recognize that the WFP projects managed to establish large plantation resources, mostly in smallholder units throughout the country, but they argue that the program's economic, social and environmental impacts are difficult to judge as there has never been a formal evaluation of any of the WFP projects. Other commentators hold that the WFP projects paid insufficient attention to technical aspects, which led to the planting of the same species, Eucalyptus camaldulensis, in different site conditions, resulting in failure on a large scale.

\section{Rehabilitated Forests at the Beginning of the Large Programs}

Since the early 1990s, following the UNCED and the era of the Tropical Forestry Action Plans, Vietnam has also embarked on major reforms of natural resource management. The two major forest rehabilitation programs of the 1990s, Program 327 and the 5MHRP, are shaped by this change (Carew-Reid et al. 1999). It is relevant, however, to highlight in more detail the status of planted forests in the early 1990s. According to Nguyen and Gilmour (1999) 670,000 ha of plantation forest existed by 1993. This is about a third of what had been planted until that date,

Table 18. Planted forests in Vietnam between 1986 and 1992

\begin{tabular}{llrllr}
\hline No & Species & Area & No & Species & Area \\
\hline 1. & Eucalyptus camaldulensis & 337357 & 12. & E. exserta & 20689 \\
\hline 2. & Pinus merkusii & 119924 & 13. & Pinus massoniana & 1,437 \\
\hline 3. & E. terelicornis & 64256 & 14. & Aleurites Montana & 14400 \\
\hline 4. & Anacardium occidentale & 43528 & 15. & Dipterocarpus spp & 9962 \\
\hline 5. & Acacia auriculijàrrnis & 43110 & 16. & Melia azedarach & 8276 \\
\hline 6. & Styrax tonkinensis & 32747 & 17. & E. urophylla & 6267 \\
\hline 7. & Bambusa & 24725 & 18. & Cassia sianiea & 6235 \\
\hline 8. & Cinnamomuin cassia & 23428 & 19. & Pinus caribaea & 5931 \\
\hline 9. & Acacia inangium & 23021 & 20. & Cunninghamia & 4908 \\
\hline 10. & Pinus kesiya & 22998 & 21. & Tectona grandis & 4678 \\
\hline 11. & Manglietia glauca & 22714 & 22. & Others & 59875 \\
\hline & Total & & & 913466 \\
\hline
\end{tabular}

Source: Nguyen N.L. (1996) 
according to Table 2.b. One excellent and detailed review of planted forests in 1992 is provided by Nguyen N.L. (1996), suggesting that the area of planted forest during the first half of the 1990s was closer to 1 million ha (Table 19).

Some more detail on the situation of plantation forests during the early 1990s is provided in the same report, corroborating Table 18, and showing the diversification of Vietnam's forest rehabilitation at that time. The GoV planned the location of supply regions around timber and wood processing centres, although spontaneous plantation development has also contributed to the location of plantations. Nguyen N.L. (1996) identifies three woodchip and paper material supply regions. One is the forestry development area in five provinces of the Red River watershed. This region is linked to the Viet Tri and Bai Bang pulp mills. In 1995 this region had 33,724 ha of Styrax tonkinensis, Manglieta glauca, various Eucalyptus species, Acacia magnum, and various Pinus species (Nguyen N. L. 1996). A similar region exists in the southeast, although plantations there had been developed by SFEs and provincial governments to meet local demand. A total area of 200-250,000 ha of plantation of Eucalyptus and Acacia species had been planted in Quang Nam, Da Nang and Kien Giang provinces.

In addition to these woodchip plantations, many larger indigenous timber species had been planted in different regions since the late 1960s. For instance, a 2-3,000 ha Pinus massoniana plantation in Quang Ninh provided props for coal mines. Pinus merkusii had been planted for resin production in many regions, some since the beginning of the $20^{\text {th }}$ century. Nguyen N.L. (1996) estimated a total area of 91,000 ha of this species. Pinus kesiya plantation covered 12,000 ha, in addition to more than 100,000 ha of natural stands, many in the high mountains of Lam Dong. Tectona grandis now covers 2,500 ha, while the oldest plantations were established in the 1920s. In northern Vietnam some 1,000 ha of Manglieta glauca had been planted.

In addition to these small scale commercial timber plantations, tree species had been planted widely for other purposes. Farmers in Yen Bai and Quang Nam had been planting important areas of Cinnamonmum cassia in small lots, bands or scattered in the mountains. Other species, like Illicium verum, and Aleuritis Montana had been planted in smaller quantities.

The accumulated experience in the planting of many tree species under many different circumstances and for many different purposes was already recorded at that time. The Forest Science Institute of Vietnam had proposed a list of 10 exotic and 82 indigenous species for planting throughout the nine ecological regions of Vietnam. These species had been assessed on whether they:

- Met the objectives of planting (environmental protection or raw material supply);

- Fit the climate and soil conditions;

- Had sufficient seed and seedling sources;

- Were represented in demonstration models that showed quality and productivity. 


\section{Contemporary Forest Rehabilitation in Vietnam}

Two programs stand out among Vietnam's efforts to rehabilitate its national forests: the so called Greening the Barren Hills Program (Program 327) and the Five Million Hectare Reforestation Project (5MHRP). They have been the largest initiatives in terms of objectives, invested funds, and for the political and international support they have received. The first, Greening the Barren Hills, started and was completed during the 1990s. The 5MHRP started in 1998 and has a final horizon of 2010.

\section{The Greening the Barren Hills Program}

The Greening the Barren Hills Program was an ambitious undertaking initiated shortly after the 1992 Rio Earth Summit. The program was officially launched by the Council of Ministers' Decision 327-CT dated 15 September 1992, and is therefore is often referred to as Program 327. The original focus of the program was very broad and ambitious, as it included all the following sectors: forestry, agriculture, aquaculture, fixed cultivation, sedentarization and new economic zones. Carew-Reid et al. (1999) see this as evidence of an improved awareness that forest degradation and rehabilitation need to be addressed through multidisciplinary and multisectoral approaches. The program's purpose was to regreen open land and barren hills, protect existing forests, assist natural regeneration and reforestation, utilize coastal alluvia, promote aquaculture, develop long-term industrial crops and fruit trees, expand cultivated land in delta areas, build infrastructure, promote social welfare and recruit labourers to project areas in order to form new communes (MARD 2001).

It is important to recognize that the actual scope of the program was much broader than just forestry, and that the forestry component of the project intersects with many other policy initiatives, like for instance forest land allocation, forest protection contracts or SFE reform, discussed previously. This makes a precise description of what the program actually entailed, and therefore what is has achieved, somewhat difficult.

In the forestry domain, Program 327 focused on rehabilitating forest cover on barren land and hills, but also on the protection of existing forest areas, natural regeneration and forest plantations. While it had this focus related to the forestry sector, quite a few other aspects, like infrastructure development and social investment, did have an important impact that also affected strictly forestry activities. This program, however, in contrast to previous initiatives, emphasized forest rehabilitation in Vietnam's highlands, while pursuing an integrated rural development approach (Sikor and Apel 1998).

The core of this program has been the allocation of substantial amounts of funds to state actors at the provincial and district levels that were put in charge of its implementation. While the project was ongoing, projects under these programs received a large share of central government transfer payments to the provinces. These amounted to some USD 70 million/year for 1993 and 1994 (Sikor 1998). Between 1993 and 1998, the GoV spent VND 2,987 billion (USD 213 million) on this program. Of this amount, $73 \%$ was spent on forestry and infrastructure; $14 \%$ on non-interest loans for agriculture; and $13 \%$ for management and administration 
purposes (Do Dinh Sam et al. 2004). MARD (2001) provides the following breakdown of VND 2,516 billion that was invested in the program: 65\% was used for forestry, $18 \%$ for infrastructure, $14 \%$ for agriculture, and 3\% for resettlement. VND 164 billion was allocated to administration and VND 368.2 billion was given in interest-free loans (i.e. a total of VND 3,048.2 billion). The funding came largely from state funds (Do Dinh Sam et al. 2004; Nguyen X.N. 2001).

Program 327 was executed through projects that were proposed and implemented by district authorities and SFEs; as grants for projects that did not generate immediate benefits to rural people like infrastructure, planting or protection of special-use forest and social services; and as credits at reduced interest rates for investments that generate financial benefits to local people (Sikor 1998). Lang (2002) estimates that somewhere between 426 and 1,200 projects were executed under the program. Authors agree that most of the funds were ultimately channelled through the 412 SFEs to individual projects implemented by these enterprises directly, or subcontracted to collective bodies and farmers. The approval of projects under the program was complex. The funds could be used for various purposes, including infrastructure, scientific and technical facilities, public welfare, reforestation and seed production, subsidies to families wishing to reclaim unused land, and interest-free loans to households living in project areas.

An important change in the focus of the project occurred during 1995, when by means of Decree 556/TTg (1995), the focus of Program 327 radically shifted to forest protection in critical watersheds, i.e., to the rehabilitation of special-use and protection forests (Sikor and Apel 1998). This included areas where slash and burn cultivation persisted, mostly in the Northern and Central Highlands. It shifted the focus of the program squarely to mountainous and midland regions and away from production forest. Because of this change, from that time funds under Program 327 were allocated to financing the establishment of forest cover within buffer zones or areas zoned for regeneration within the boundary of special-use forests. In effect, a large part of the funds was designated to finance activities under Decree 01/CP, which defined forest protection and reforestation contracts (ICEM 2003).

\section{Achievements}

There is considerable variation in the reported achievements that have been attributed to Program 327. Some of the achievements should be attributed to the range of programs, projects and policies that were implemented during much of the 1990s.

Morris and Ingles (2003) estimate that 299,000 ha of forest were successfully regenerated under Program 327, and 397,000 ha of new plantations were established. They do not give any indication of who was involved in this regeneration and under what kind of arrangement it was achieved. Both Morris and Ingles (2003) and Nguyen X.N. (2001) report that in addition to these forest rehabilitation results, 1.6 million ha were given out in Forest Protection Contracts to some 466,000 households. Castrén (1999) estimates that an area of 6,791,700 ha of forest was protected as a result of Program 327 (of 5,477,600 ha that was intended to be protected).

Nguyen X.N. (2001), on the other hand, calculates that under Program 327, 
some 700,000 ha of forests were enriched or planted and 640,000 ha of new forests were established. The program also yielded 88,729 ha of industrial tree crops and fruit trees and 31,290 ha of family gardens. As other outcomes the same author lists that Program 327 generated 466,678 jobs, built 5,009 km of rural roads, constructed $86,505 \mathrm{~m}^{2}$ of schools and $16,755 \mathrm{~m}^{2}$ of medical stations, supported thousands of small scale irrigation projects, and supplied safe water for more than 20,000 households. These results are corroborated by Salmi et al. (1999), and are apparently based on a MARD report from 1998 (MARD 1998).

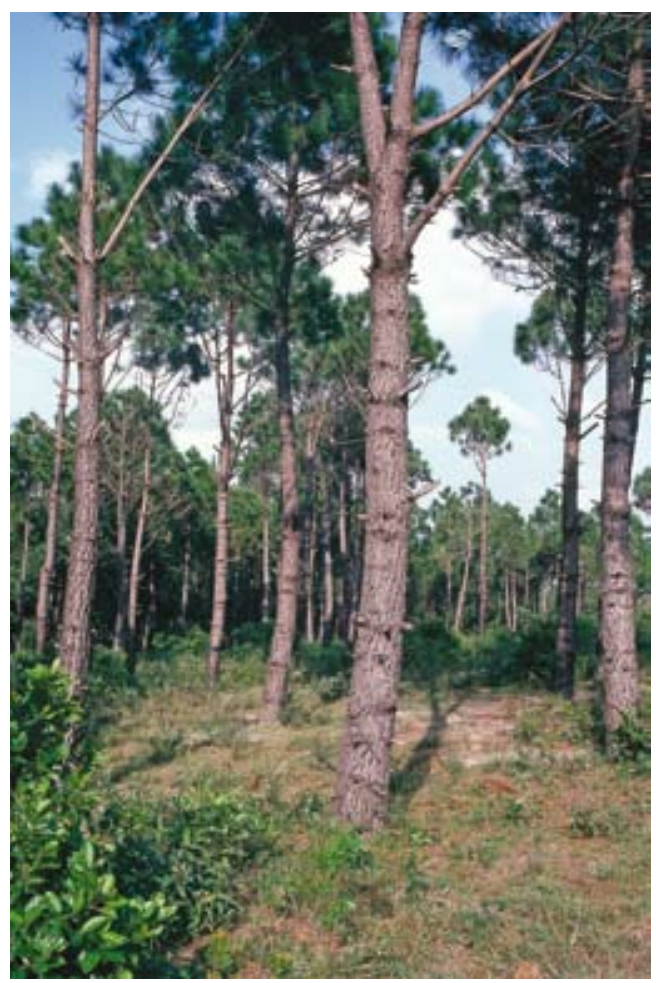

Bo Trach, $520 \mathrm{~km}$ south of Hanoi, Bin Tri Tienh seed enterprise. Stand of Pinus merkusii lopped by local residents for firewood - Vietnam. (Photo by Christian Cossalter)

Despite these reported positive results, quite a few considerations have to be made as to the success of the program. MARD (2001:6) and Lang (2002) cite a ForTech report, commissioned by the World Bank, which evaluates the program. The report was very critical of the program; some feel unjustly so (Carew-Reid et al. 1999). According to the ForTech report, the program was too topdown, the land allocation was not participatory, reforestation applied poor silvicultural practices, and the project was imposed on poor people without their input (Lang 2002). The reforestation efforts undertaken on allocated forest land were unrealistic (MARD 2001).

Inaddition totheseimplementation problems, Vietnam's State Planning Committee estimated that the district authorities and SFEs that obtained 327 funds diverted over $50 \%$ to other purposes (Sikor 1998). The program was used to finance several ongoing government programs; the Resettlement and Sedentarization Program, for instance, received funding priority out of the Program 327 budget. Funds from this program essentially allowed SFEs to continue to operate even though they were no longer economically viable. At the same time, 327 funds were used to promote tree planting on land crucial for food production (Sikor 1998).

Nguyen and Gilmour (1999) touch on some more technical aspects of Program 327. They point out that most of the tree planting conducted during the 1990s relied on a few fast-growing exotics such as Eucalyptus, Caribaea pine and Acacia, although this information contradicts the suggestion by Nguyen N.L. (1996) of significant use of indigenous species in forest rehabilitation in Vietnam. These species served well to restore forest cover on denuded land with poor soils, but only managed to 
achieve low productivity. This was in part a result of the use of poor quality seed and seedlings and poor planting techniques. The plantations established under these programs achieved a supply of small sized logs for industrial purposes and as cash crops (i.e. cinnamon), but plantations with more demanding species planted for the production of large sized timber tree were not successful. Nguyen and Gilmour (1999) agree that planting species such as Hopea odorata, Dipterocarpus alatus, and Tectona grandis was successful on the red-yellow ferralite and grey soils in the Central Highlands and the Mekong delta.

\section{The Five Million Hectare Reforestation Project ${ }^{8}$}

The 5MHRP is the latest, still ongoing, major effort in Vietnam related to forest rehabilitation. The project was approved by Parliament in 1997 and by the Prime Minister with Decision No. 661/QD-TT dated 29 July 1998, hence many of the projects are referred to as Decision 661 projects. The 5MHRP was scheduled to run between 1998 and 2010 .

The stated objectives of 5MHRP are as follows (GoV 2005):

- Reforest 5 million ha of land: 2 million ha of special-use forest and protection forest and 3 million ha of production forest. (See also Chapter Two).

- Assure a forest product supply of 1.5 million $\mathrm{m}^{3}$ of timber and 20 million steres of fuelwood, in part also to reduce pressure on natural forests.

- Create employment for 2 million people and increase incomes of people in forest areas as a contribution to poverty alleviation, hunger eradication and the development of rural mountainous areas.

These objectives imply that the 5MHRP returned to some of the original objectives of Program 327, which, in its initial design, also intended to promote forestry production (i.e. promote the establishment of production forest). However, like its predecessor, the 5MHRP actually only funds the reforestation of protection and special-use forest, although it creates favourable conditions for production forests, as explained in Chapter Two. The reforestation of production forest is not to be subsidized by the government; rather, it is to be carried out by economic actors for their own benefit, using commercial loans (although on preferable terms, see Chapter Two).

In order to meet the stated objectives of this ambitious project, the following measures were to be undertaken:

- Speed up forest land allocation

- Support projects for protection and special-use forest

- Provide favourable loans to farmers for production forest rehabilitation

- Propose new benefit sharing policies, finally adopted in 2004

- Provide training and extension services

- Encourage joint ventures and foreign investment by imposing low taxes and providing adequate land use rights

- SFEs to provide technical support and technology transfer.

\footnotetext{
${ }^{8}$ Although larger in scale than Program 327, Carew-Reid et al. (1999) report that the 5 million ha reforestation initiative is technically a project, and not a program.
} 
Table 19. Sources of the 5MHRP investments

\begin{tabular}{|c|c|c|}
\hline Origin of funds & Amount [VND 106] & USD Equivalent $\left[10^{6}\right]$ \\
\hline State budget & 2443970 & 163 \\
\hline Credit loans & 920664 & 61 \\
\hline Overseas funds & 279558 & 15 \\
\hline Self-finance of enterprises & 164913 & 11 \\
\hline Other sources & 87250 & 6 \\
\hline Total invested funds & 3848355 & 256 \\
\hline
\end{tabular}

According to a recent assessment of the Forestry Department (MARD 2003) between 1998 and 2003, a total budget of VND 3,848 billion (about USD 256 million) was allocated to this project (Table 19). State budget funds accounted for VND 2,444 billion (about USD 163 million), or 63.5\%. Loans contributed VND 920 billion (about USD 61 million) or 24\%, and donor funds contributed VND 231 billion (about USD 15 million) or 6\%. Lastly, self-financed activities contributed VND 164 billion (about USD 11 million) or 4.3\%. According to this breakdown, the GoV has contributed the largest share to the implementation of the 5MHRP. In second place was loans, which were mainly invested in production forests (Do Dinh Sam et al. 2004).

\section{Achievements}

The progress of the 5MHRP is not easy to assess. Do Dinh Sam et al. (2004) report good progress on rehabilitating and protecting Vietnam's forests. The increase in forest coverage from 33.2\% in 1999 to $35.8 \%$ in 2003 does suggest success. Progress towards forest plantation establishment targets has also been according to annual plans. However, after six years, 1,196,594 ha of protection and special-use forests had been planted, an area that equalled just $49.7 \%$ of the area planned for that period (Table 20). During the same period, 516,629 ha of production forest were planted. This included 443,833 ha of industrial plantation, or $22.2 \%$ of the planned area.

It is also not easy to link the success to certain initiatives and actors. The achievements of the international cooperation projects, for instance, are added as achievements of the 5MHRP. 5MHRP is the sum of activities in Vietnam leading to meeting these targets, irrespective of who does the reforestation-i.e., Management Boards, SFEs or farmers-or how it is done (Nguyen V.T. et al. 2000). It reflects all reforestation activities in Vietnam. However, as per the available information, by 2003 the 5 MHRP had achieved approximately 2 million out of the planned 5 million ha of improved forest management or rehabilitation. The majority of the achievements have been in the area of protection and special-use forest, whereas performance in production forest is lagging behind targets (Do Dinh Sam et al. 2004).

The 5MHRP does encounter some difficulties. One of them is a lack of funds, as the state budget only meets $68 \%$ of the required annual funds. A second is that many 
Table 20. Achievements of 5MHRP projects from 1998 to 2003 [ha]

\begin{tabular}{lrrr}
\hline Target & Result & $\begin{array}{r}\text { Planned by } \\
\mathbf{2 0 0 3}\end{array}$ & $\begin{array}{r}\text { Planned by } \\
\mathbf{2 0 1 0}\end{array}$ \\
\hline Forest allocated for protection & 2432960 & 1740250 & \\
\hline Afforestation & & \\
\hline Protection Forests, Special-Use Forests & 1196594 & 949144 & \\
\hline$\quad$ Newly planted & & 496803 & 1000000 \\
\hline$\quad$ Natural regeneration & 452341 & 1000000 \\
\hline $\begin{array}{l}\text { Production Forests } \\
\quad \begin{array}{l}\text { Forests supplying industrial } \\
\text { materials }\end{array}\end{array}$ & & 3000000 \\
\hline$\quad$ Industrial plants, fruit trees & & 2000000 \\
\hline Total afforestation & & & 1000000 \\
\hline
\end{tabular}

Source: Do Dinh Sam et al. 2004.

farmers with access to production forest land have no interest in loans with annual preferential interest rates of $5.4 \%$ because their revenue is insufficient to pay such interest. A third limitation is that land allocation and land use planning has not met the actual requirements. In particular, it is difficult to identify land that is suitably located for forestry production, and to supply raw materials for processing factories. Even though under this program, forest owners can benefit more from forests, the incentives are inadequate to attract other people to engage in forest protection and rehabilitation activities.

\section{International Contributions to Program 327 and 5MHRP}

Although not adequately represented in Table 19, the 5MHRP activities concentrated international cooperation in forestry. The project was discussed and endorsed at the Consultative Group meeting in Paris, at which time various members of this group pledged financial support. Some 21 cooperation agencies have signed the Memorandum of Agreement for the Forest Sector Support Program and Partnership, a partnership that was initially established to support the 5MHRP.

Carew-Reid et al. (1999) and Phan T.H. and Wattez (1991), in their review of Vietnam's ODA assistance, observe that the national increase in forest rehabilitation efforts since 1986 received important support from donors. In overall terms, between 1985 and 2000 some $80 \%$ of environmental ODA, or USD 304 million, went to the natural resource sector and predominantly to upland areas. Of this, 55\%, or USD 173.6 million, went to rural development and watershed management and tree planting projects. Between 1985 and 1995 some 252 donor-funded environmental projects were implemented (Phan T.H. and Wattez 1991). In 1995 WFP was the principal environmental donor, with 10 projects worth a total USD 143 million (Carew-Reid et al. 1999, see also the discussion above). During much of the 1990s, projects from 
WFP, ${ }^{9}$ UNDP and FAO programs and from the governments of Sweden, Germany, Japan, Holland and Finland, as well as NGOs such as WWF, CARE and OXFAM, were (and still are) being implemented. Vietnam established new official relations with international funding agencies only after 1993. Most ADB and WB projects only began in 1996. By 1998 ADB had 16 ongoing or committed projects worth a total of USD 120 million, while the WB had four such projects worth a total of USD 117 million.

These projects, where they concern forest rehabilitation, are being assigned to the 5MHRP. The exact contribution of the ODAfunded forestry projects to forest rehabilitation is therefore not clear, but most upland rural development and watershed management projects included aims to increase rural

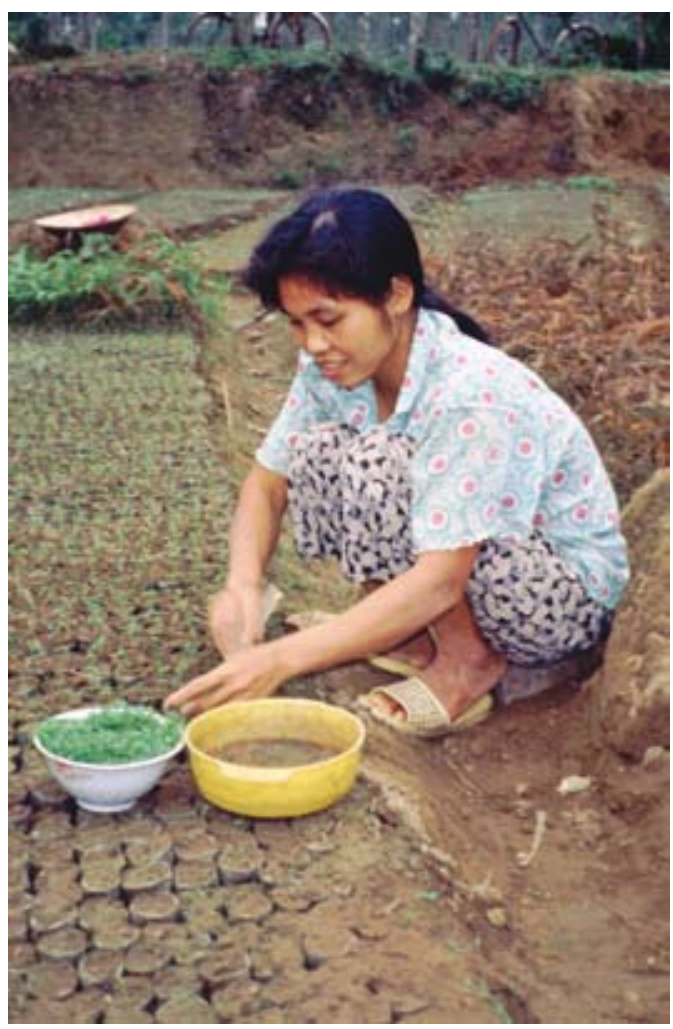

Prieking out Eucalyptus Camaldulensis seedlings in a nursery. (Photo by John Turnbull) income generation through the establishment of smallholder plantations (Carew-Reid 1999). This suggests that the ODA contribution to Vietnam's forest rehabilitation is larger than some of the figures in the previous sections suggest.

\footnotetext{
${ }^{9}$ Ongoing projects, like those carried out under the WFP program, and Program 327, were incorporated into the 5MHRP.
} 


\section{Chapter 4 \\ A Survey of Forest Rehabilitation Projects}

This chapter analyzes ongoing forest rehabilitation projects to provide an overview of contemporary forest rehabilitation in Vietnam. The data stem from three sources, as explained in the Methodology section of Chapter One. In our survey of the national statistics on forest rehabilitation projects we recorded 304 projects, but obtained adequate data on only 280 projects. A questionnaire guided the data collection on 42 rehabilitation projects chosen to represent the country's three forest types, ecological zones, and main source of funding. In-depth interviews of 15 projects, which included field visits and interviews with various stakeholder groups, completed this data set.

The results below represent the most relevant findings of this study. The results can roughly be divided into three groups. The first group of results relates to the characteristics of the forest rehabilitation projects themselves, and included data like geographic distribution, main objectives, funding source, and initiating and executing agencies. Data presented in that section helps provide an understanding of Vietnam's forest rehabilitation strategy. The second group of results relates to project implementation, including technical aspects, to characterize how forest rehabilitation is carried out within individual projects. The third group of results is related to the outcomes of the forest rehabilitation projects. This set of data provides further evidence to how successful forest rehabilitation in Vietnam has been.

\section{An Overview of Forest Rehabilitation Projects in Vietnam}

The Northern Mountains region is the largest of the seven regions in Vietnam, and the greatest number of rehabilitation projects (Figure 3, Table 21) has been carried out in this region (75 projects). In terms of number of projects, the Central Coastal region is next (69), followed by the North Central region (55), the Mekong River Delta (31) and the High Plateau (25).

The three types of forest defined in the Forest Protection and Development Law (1991) are useful to group forest rehabilitation projects. As a rule, the purpose of the 
rehabilitation projects on each type of forest land is consistent with the forest land on which the project takes place, i.e., the restoration or preservation of some forestrelated function when it concerns protection forest land; some kind of production objective when it concerns production forest land; or some other purpose in the case of special-use forest land. For this reason, in the general inventory the team distinguished between projects related to the three forest types. It is important to note, however, that: (1) our assessment of the distribution of projects is based on a 280-project sample, and not a full survey of all rehabilitation projects ever carried out, and we do not know if there is any bias in our data; (2) even though we group projects into three categories according to forest type, individual projects more often than not encompass multiple objectives (see Table 26 and related discussion below.)

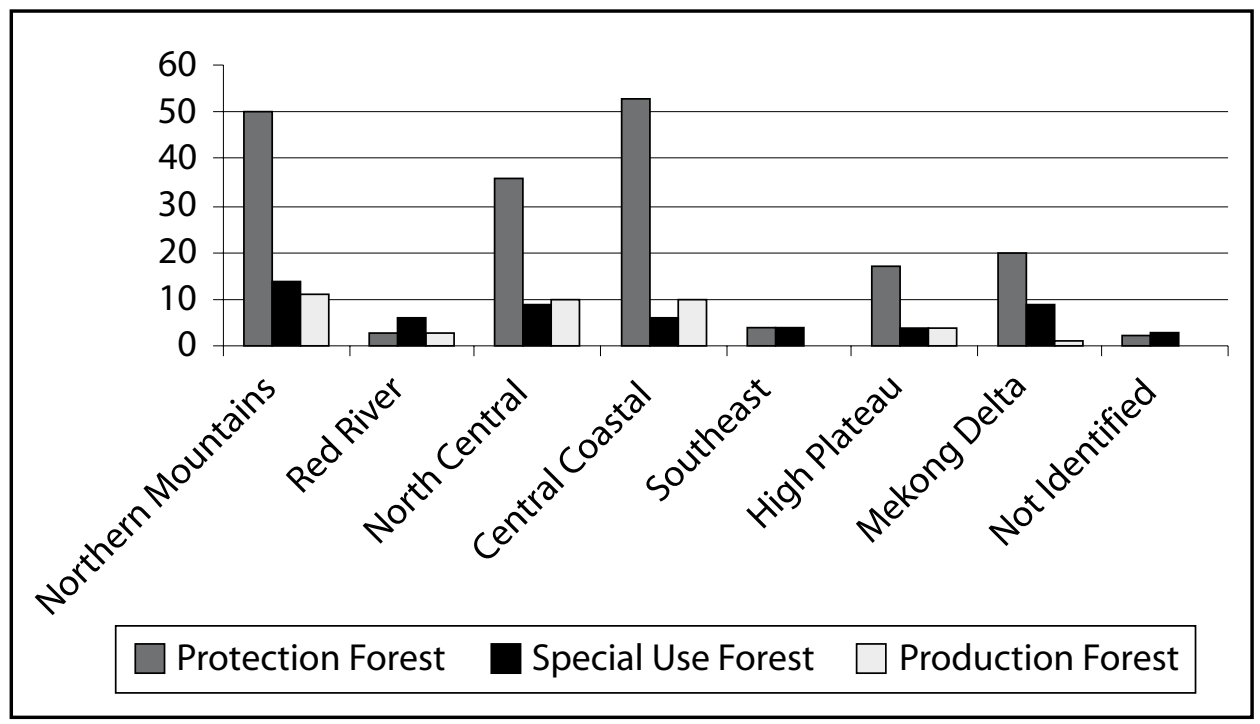

Figure 3. Number of projects by ecological region and type of forest

Table 21. Projects by forest type, region and source of funding

\begin{tabular}{llllllllll}
\hline $\begin{array}{l}\text { Type of } \\
\text { project }\end{array}$ & $\begin{array}{l}\text { Northern } \\
\text { Mountains }\end{array}$ & $\begin{array}{l}\text { Red River } \\
\text { Delta }\end{array}$ & $\begin{array}{l}\text { North } \\
\text { Central }\end{array}$ & $\begin{array}{l}\text { Central } \\
\text { Coast }\end{array}$ & Southeast & $\begin{array}{l}\text { High } \\
\text { Plateau }\end{array}$ & $\begin{array}{l}\text { Mekong } \\
\text { Delta }\end{array}$ & $\begin{array}{l}\text { Not } \\
\text { known }\end{array}$ & Total \\
\hline $\begin{array}{l}\text { Protection } \\
\text { forest }\end{array}$ & $45 / 5^{*}$ & $3 / 0$ & $34 / 2$ & $53 / 0$ & $4 / 0$ & $16 / 1$ & $18 / 2$ & $2 / 0$ & $175 / 10$ \\
\hline $\begin{array}{l}\text { Special-use } \\
\text { forest }\end{array}$ & $10 / 4$ & $5 / 1$ & $7 / 2$ & $6 / 0$ & $4 / 0$ & $3 / 1$ & $8 / 1$ & $0 / 3$ & $43 / 12$ \\
\hline $\begin{array}{l}\text { Production } \\
\text { forest }\end{array}$ & $4 / 7$ & $2 / 1$ & $2 / 8$ & $7 / 3$ & 0 & $1 / 3$ & $0 / 2$ & 0 & $16 / 24$ \\
\hline Total & $59 / 16$ & $10 / 2$ & $43 / 12$ & $66 / 3$ & $8 / 0$ & $20 / 5$ & $26 / 5$ & $2 / 3$ & $234 / 46$ \\
\hline
\end{tabular}

* Fractions reflect 'State funded/International funded' 


\section{Protection Forest Rehabilitation Projects}

As per our inventory (Figure 3, Table 21), the largest number of projects are linked to protection forest land (185 projects or 61\%). Most of these projects are located in the Central Coastal region and Northern Mountains region (50 and 53 projects), followed by the North Central region (36), the Mekong River Delta region (20) and the High Plateau (17). This distribution reflects the need to develop protection forest in these regions, because floods occur frequently. Most of these projects involve establishing watershed forests that regulate water flow in the watersheds of the $\mathrm{Da}$, Lo and Red rivers in the Northern region, the Hinh, Cau and Ma rivers in the North Central region, and the Con river and the Danhim waterfall in the Southern region. The protection forests established under these rehabilitation projects also protect important lakes such as Nui Coc, Yen Lap, Dai Ninh, Dau Tieng and Tri An. In the Central Region the projects are intended to establish protection forests on sandy terrain to eliminate erosion in the coastal areas of the Mekong Delta.

\section{Special-use Forest Rehabilitation Projects}

Our inventory recorded 55 projects (18\%) linked to special-use forests and 12 of those were supported by international funds. The number of special-use rehabilitation projects is significantly higher than the number of production forest rehabilitation projects, and highest in the Northern Mountains region (14 projects). Regions with the lowest number of special-use forest rehabilitation projects were the High Plateau region and Southeast region, with only four projects.

The inventory showed a subset of projects related to national parks, e.g. Cuc Phuong National Park (Ninh Binh province), Cat Ba (Hai Phong), Binh ChauPhuoc Buu (Ba Ria Vung Tau province), Tram Chim (Dong Thap province), Cat Tien (Dong Nai and Lam Dong province), Con Dao, Phu Quoc (Kien Giang province), U Minh Thuong (Kien Giang province) and many other nature reserves. The projects are implemented in many different ecological zones and include high mountains, limestone mountains, and mangrove forest areas.

\section{Projects on Production Forest Land}

The study identified 40 projects related to production forests (13\%). The majority (24 projects) were sponsored by international funds or funded through a joint venture investment (one project, i.e. ViJachip). Projects on production forest land are mainly located in three zones: the Northern Mountains and the North Central and Central Coastal regions. The production forest projects identified here supply three types of resources:

- Raw material for paper production, especially in the Northern Mountains region and the Central High Plateau (e.g. afforestation projects for raw materials in Gia Lai and Hoa Binh province, forests for paper materials in Vinh Phu province).

- Woodchips (many projects, for instance the ViJachip project), and MDF (afforestation project supplying MDF factories in Gia Lai province).

- Valuable wood from indigenous tree species (projects in Tuy Hoa-Phu Yen provinces). 
WFP, KfW and JIBRO-supported projects, for example, promote the production of raw materials for paper production, woodchips, and furniture.

\section{Projects Supporting Forest Rehabilitation Projects}

Besides the rehabilitation projects summarized above, there are several types of projects that provide support to other rehabilitation projects. They include:

- Technical assistance projects. These projects assess, for example, the feasibility of the production of MDF materials in certain zones to supply factories in Gia Lai province, or they focus on research, for instance of the planning of Australian Acacia species in Vietnam and China. A third type provided technical assistance projects to the WFP projects.

- Seed production projects.

- Social forestry projects-these projects include rehabilitation efforts, but that is not their main and only focus. They include projects that focus on communal forest management, forest management in nature reserves, and on participatory land allocation techniques.

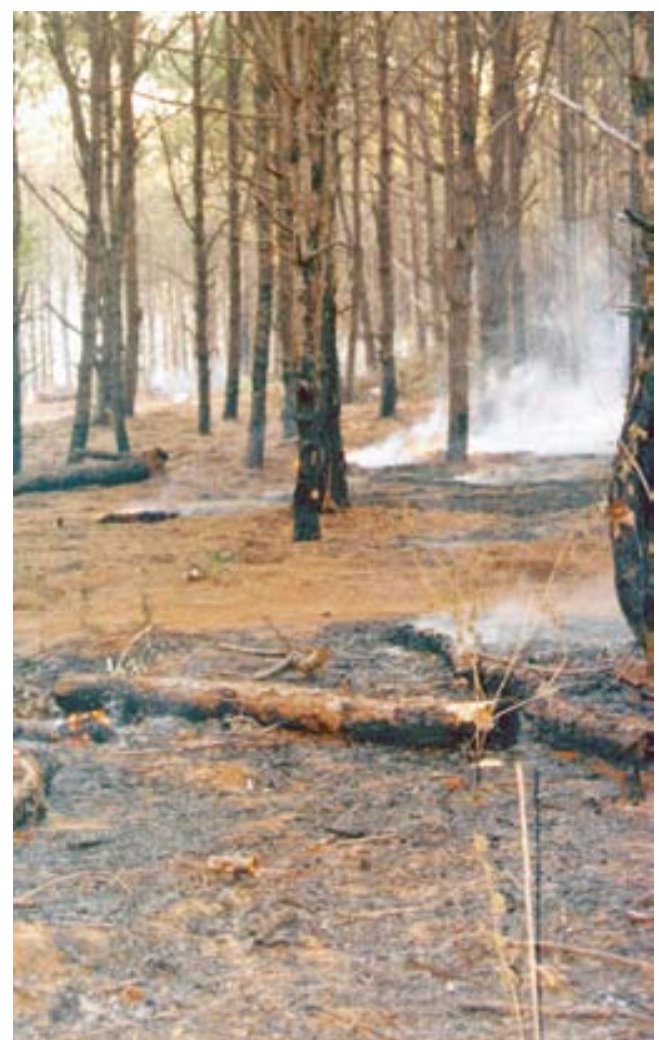

Forest fires are one of the threats of forest plantations in Vietnam. (Photo by Philippe Guizol)

\section{Features of Vietnam's Forest Rehabilitation Projects}

This section provides a more detailed characterization of the forest rehabilitation projects, using the results of the 42-project survey and some results from the survey of all projects.

The projects that we reviewed varied considerably in the areas they addressed (Table 22). Of the 42 reviewed projects, only 32 could specify the target area. The average for these 32 projects was 118,531 ha, with a total area of 3.8 million ha. Projects in special-use forest had a much smaller average area $(13,011 \mathrm{ha})$, while protection forest rehabilitation areas had an average target area of 157,584 ha.

These figures do suggest different points. The 3.8 million ha covered by the projects we surveyed comprises $23.7 \%$ of Vietnam's 16.2 million ha of projected forest land. The data also suggest that the 42 projects included a selection of large projects. Using the 118,531 ha average and multiplying it by 304 , the total number 
of projects recorded in this study, would suggest that the entire area of Vietnam is covered by forest rehabilitation projects. ${ }^{10}$ An alternative interpretation is that indeed a large area of forest land that is in need of rehabilitation is being covered by projects.

Table 22. Area coverage of reviewed rehabilitation projects

\begin{tabular}{lrrrrr}
\hline Project type & Production & Protection & Special-use & Total \\
\hline Number of projects & 6 & 20 & 6 & 32 \\
\hline Total Area & 563245 & 3151695 & 78066 & 3793006 \\
\hline Maximum Area & 274411 & 2606500 & 24823 & 2606500 \\
\hline Minimum Area & 780 & 6000 & 4926 & 780 \\
\hline No data & 3 & 6 & 1 & 10 \\
\hline Average Area & 93874 & 157584 & 13011 & 118531 \\
\hline
\end{tabular}

The survey inquired about the dominant topography of the forest rehabilitation projects. The results are presented in Table 23 . The majority of projects-28 out of 42 projects, or $67 \%$ - are being carried out on moderately undulating terrain (the categories are: sloping and plain; sloping; hills, plain and coastal region; and low rolling hills). Only six projects (14\%) were carried out in steep terrain, while just five $(12 \%)$ were located on largely flat terrain.

Table 23. Dominant topography of forest rehabilitation projects

\begin{tabular}{lrrrr}
\hline Project's dominant topography & Prod & Prot & SpU & Total \\
\hline Alluvial, wetland, estuary & 1 & 1 & 1 & 3 \\
\hline Plain & & 1 & 1 & 2 \\
\hline Plain, rolling, moderately steep and steep slopes & & 1 & & 1 \\
\hline Sloping and plain & 3 & 1 & & 1 \\
\hline Sloping & & 1 & & 21 \\
\hline Hills, plain and coastal region & 2 & 2 & & 1 \\
\hline Low hills, rolling & & 1 & & 1 \\
\hline Hills with some higher tops & 1 & 3 & 1 & 5 \\
\hline $\begin{array}{l}\text { Strongly partitioned low mountains and } \\
\text { midlands, moderately steep }\end{array}$ & 2 & 1 & & 3 \\
\hline No data & & & & \\
\hline
\end{tabular}

Table 24 presents the dominant soil fertility of the project locations. There is a slight over-representation of poorer soil conditions, as 12 out of the 42 projects were

${ }^{10} 304$ times $118,531=36033424$ ha or more than Vietnam's total area 
on good, average-to-rich and average soils, while 20 projects were executed on soils that had average-to-poor or poor soil conditions. The data showed little evidence of a relationship between project type and soil fertility.

The results from Table 24 appear to the question observation that commercial tree plantations are mostly located on the poorest soils, and even more so that good soils with high fertility would naturally be dedicated to agricultural production rather than tree plantations. The results from Table 23, on the other hand, suggest that the majority of forest rehabilitation is not happening on terrain with steep sloops, or mountains, where it may be most urgent.

Table 24. Soil fertility in forest rehabilitation projects

\begin{tabular}{lc}
\hline Soil fertility & Total \\
\hline Good, high & 3 \\
\hline Average to rich & 1 \\
\hline Average & 8 \\
\hline Average to poor & 9 \\
\hline Low, poor, bad draining, high acidity & 7 \\
\hline Blank & 14 \\
\hline Total & 42 \\
\hline
\end{tabular}

The forest rehabilitation projects in the survey responded to various causes of degradation, as listed in Table 25. Logging, grazing, fire and flood were the most frequent causes of degradation, followed only in the fifth place by agricultural production. Logging and fire as causes of degradation were more often linked to protection forest rehabilitation projects. Agricultural production as a cause of degradation dominated the production forest rehabilitation projects.

Table 25. Causes of degradation leading to forest rehabilitation projects

\begin{tabular}{lrrrr}
\hline Cause of degradation & Prod & Prot & SpU & Total \\
\hline Agricultural production & 5 & 7 & 1 & 13 \\
\hline Fire & 1 & 17 & 3 & 21 \\
\hline Forest exploitation & 4 & 5 & 1 & 10 \\
\hline Grazing & 3 & 15 & 3 & 21 \\
\hline Flood & 2 & 14 & 3 & 19 \\
\hline Logging & 5 & 20 & 5 & 30 \\
\hline Other & 3 & 6 & 3 & 12 \\
\hline Total & 23 & 84 & 19 & $126^{*}$ \\
\hline
\end{tabular}

* Totals exceed 42 sampled projects because single projects list different causes of degradation 


\section{Objectives and Duration}

We reiterate that in Vietnam the three forest types each have a specific key objective: protection forest to protect upstream areas of watersheds or control sand movements in coastal formations; special-use forest to conserve natural or cultural heritage; production forest to supply forest products. However, single forest types, and subsequently projects to rehabilitate particular forest types, as a rule pursue more than one objective.

The objectives of the projects that we reviewed can be grouped into seven categories, as indicated in Table 26. The most frequent objective of the projects reviewed was catchments or biodiversity protection. If we assume that restoring forest cover and regreening are similar objectives, then this objective was mentioned 74 out of 135 times in 42 projects. Noticeably, although these objectives were most frequently mentioned in protection forest projects and special-use forest projects, they had also had a significant score in production forest projects. The second most frequent objective related to addressing poverty, rural development or generating employment.

Table 26. Forest rehabilitation project objectives

\begin{tabular}{lrrrr}
\hline Objective of rehabilitation & Prod & Prot & SpU & Totals \\
\hline Catchments protection/biodiversity conservation & 6 & 40 & 12 & $58^{*}$ \\
\hline Restore forest cover/regreening & 5 & 7 & 4 & 16 \\
\hline Poverty, rural development, employment & 6 & 21 & 2 & 29 \\
\hline Promoting tourism & 1 & 3 & 3 & 7 \\
\hline Production & 6 & 8 & & 14 \\
\hline Knowledge \& technology creation & 1 & 3 & 1 & 5 \\
\hline Others & 3 & 2 & 1 & 6 \\
\hline Totals & 28 & 84 & 23 & 135 \\
\hline
\end{tabular}

* Totals exceed 42 sampled projects because single projects list different objectives

A close link is to be expected between the objectives that characterize forest rehabilitation projects and the beneficiaries of these projects. The survey of 42 projects inquired about who are the main beneficiaries (Table 27). Local people were said to benefit from all the surveyed production, protection and special-use forest projects. Companies and enterprises benefited only from six production forest projects and tourists and tourist companies were the beneficiaries of three protection forest and three special-use forest projects.

Figure 4 shows the beginning and duration of projects that were surveyed. The majority of projects in this figure started around 2000 and are scheduled to finish around 2010. This reflects the link of these projects to the 5MHRP, which started in 1998 and is to be completed by 2010 . 
Table 27. Beneficiaries of forest rehabilitation projects

\begin{tabular}{lrrrr}
\hline Beneficiaries & Prod & Prot & SpU & Total \\
\hline Local people & 9 & 26 & 7 & 42 \\
\hline Companies, enterprises & 6 & & & 6 \\
\hline Non local/public & 4 & 26 & 6 & 40 \\
\hline Tourists/tour operators & & 3 & 3 & 6 \\
\hline Executors & 3 & 1 & & 4 \\
\hline Total & 23 & 60 & 16 & 99 \\
\hline
\end{tabular}

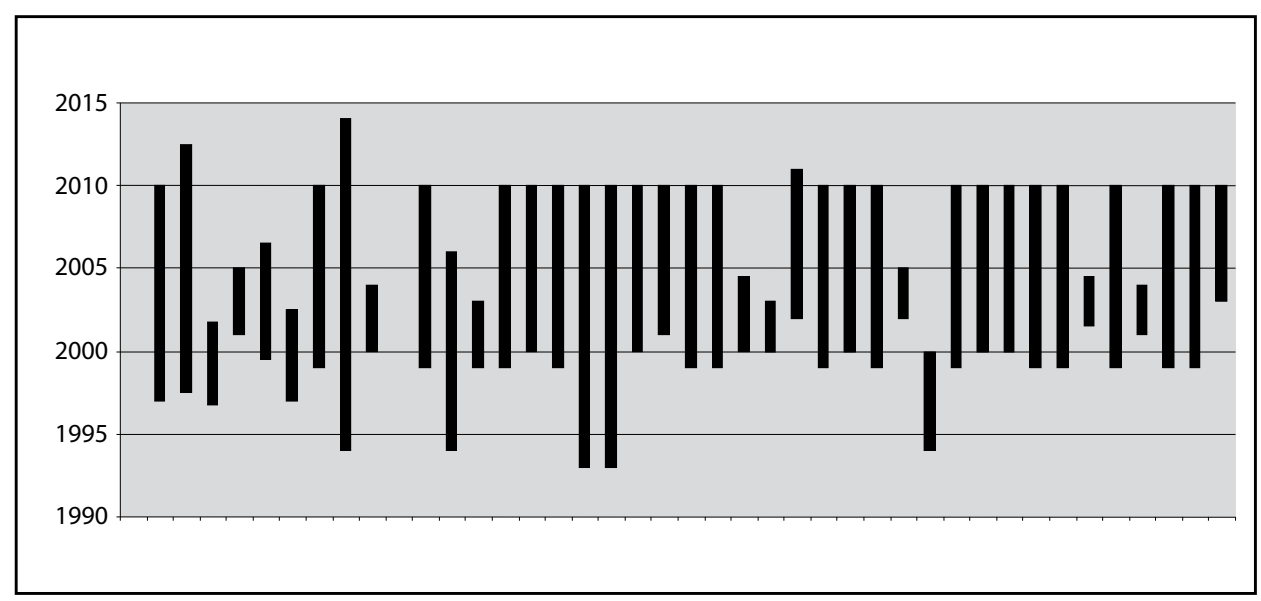

Figure 4. Beginning and duration of forest rehabilitation projects

According to the survey, the executing agencies of forest rehabilitation projects can be grouped into eight categories (Table 28). These eight categories suggest a division between state executing agencies (DARD, forestry agencies, People's Committees), and private and state company executing agencies. An important number of projects had more than one implementing agency, in which case the role and responsibilities of different executing agencies varied. For instance, in many cases forest rehabilitation projects are under supervision of People's Committees and Project Management Boards. In such a case, the Project Management Board is under the supervision of the People's Committee, and is the direct implementing unit.

Funding sources for forest rehabilitation projects can be divided into national and international funds. Each of these two groups can be subdivided as indicated in Table 29. Of the 280 projects with adequate data, only 46 projects (16\%) are funded with international funds. (But see also Chapters Two and Three on this issue.)

Table 30 shows the distribution of funding sources for the projects. The total number of funding sources is 46; two projects gave two funding sources, and one project three funding sources. The table shows that the majority of projects are supported by Vietnamese funds (31 out of 46). The majority of these projects 
were funded out of 5MHRP funds, including the state budget from MARD. Five out of seven projects that had foreign funding included production forest-related projects, confirming the results from the survey of 280 rehabilitation projects. The vast majority of protection forest projects and special-use forest projects were funded from Vietnam's state coffers.

Table 30, which includes information on the funding origin of all the surveyed projects, suggests that funds for rehabilitation of protection forests come mainly from the state budget line for the 5MHRP (equal to $95 \%$ or 175 out of 185 projects). International funds are partly non-repayment funds from the World Bank, Denmark and Japan, and the remainder are loans from the World Bank, DANIDA and JBIC (Do Dinh Sam et al. 2004). Many international organizations are interested in biodiversity conservation and support the rehabilitation of special-use forests, e.g. GEF, UNDP, GTZ, EU, DANIDA, WB, and the Netherlands government. International funds for projects on production forest land are mainly ODA nonrepayment funds. Only a few larger projects are funded by ODA loans (ViJachip, projects supplying MDF materials, etc.).

Table 28. Project executing agencies

\begin{tabular}{lrrrr}
\hline Executing agency & Prod & Prot & SpU & Total \\
\hline DARD & & 12 & 12 \\
\hline Forestry agency & 2 & 10 & 4 & 14 \\
\hline People's Committee & 2 & 18 & 8 & 28 \\
\hline Management Board/Project Management Unit & 8 & 6 & 14 \\
\hline SFE/ FE & 1 & 2 & 1 \\
\hline Donor & 4 & 1 & 5 \\
\hline Science agency & 1 & 1 & 1 \\
\hline Others & 18 & 49 & 12 & $79^{*}$ \\
\hline Totals & & 1 & 3 \\
\hline
\end{tabular}

*Total exceed 42 sampled projects because single project had multiple executing agencies

Table 29. Funding sources for forest rehabilitation projects

\begin{tabular}{ll}
\hline National Funds & State budget \\
\hline & Loan \\
\hline Direct Investment \\
\hline Self-financed \\
\hline & Technical assistance funds \\
\hline ODA non-repayment fund \\
\hline ODA loan \\
\hline
\end{tabular}


Table 30. Main project funding sources

\begin{tabular}{lrrrr}
\hline Funding agency & Prod & Prot & SpU & Total \\
\hline Vietnamese government funding & & & & \\
\hline GoV - 661 & & 22 & 4 & 26 \\
\hline MARD & 1 & & & 3 \\
\hline $\begin{array}{l}\text { Central Northern Forest Production \& } \\
\text { Science Center and other members }\end{array}$ & 1 & & & 1 \\
\hline Loan National Support Fund & & & & 1 \\
\hline Vietnamese private funding & 1 & & & 1 \\
\hline NFORIMEX II & 1 & & & 1 \\
\hline NISSHOIWAI Corporation & 1 & & & 1 \\
\hline Vietnam Forestry Company & & & & \\
\hline Foreign funding & 3 & 1 & 1 & 1 \\
\hline German funding & 1 & & & 1 \\
\hline Japan government & 1 & & & 1 \\
\hline Korea government & & 1 & & 1 \\
\hline BADC & & & 1 & 1 \\
\hline ZSCSP & 13 & 26 & 7 & 46 \\
\hline Total & & &
\end{tabular}

Table 31 gives the forest rehabilitation methods used in the 42 projects surveyed. Some form of plantation continues to be the dominant method of forest rehabilitation. Plantation included agroforestry and intercropping methods. Forest rehabilitation through protection using natural regeneration or combined enrichment and natural regeneration, was particularly relevant in protection forest and special-use forest

Table 31. Rehabilitation methods used

\begin{tabular}{lrrrr}
\hline Rehabilitation method & Prod & Prot & SpU & Total \\
\hline Natural regeneration & 3 & 15 & 7 & 25 \\
\hline Natural regeneration \& enrichment & 3 & 4 & 1 & 8 \\
\hline Enrichment & & 4 & 2 & 6 \\
\hline Protection & 1 & 7 & 2 & 10 \\
\hline Plantation with natural regeneration & 1 & 2 & & 3 \\
\hline Plantation, replanting & 8 & 22 & 7 & 37 \\
\hline Agroforestry, intercropping & 2 & 15 & 1 & 18 \\
\hline Grand Total & 17 & 62 & 18 & $97^{*}$ \\
\hline
\end{tabular}

* Total exceeds 42 sampled projects because single projects used more than one rehabilitation method 


\section{Outcomes of Vietnam's Forest Rehabilitation Projects}

This section deals with the outcomes of the forest rehabilitation projects in our survey. The data presented here are largely from the survey of 15 projects and partly from the survey of 42 projects. With regard to the results from the 15 -project survey, no distinction is made between projects according to forest types, since the sample number is too small.

The survey asked the interviewees to assess whether the project achieved the major and specific objectives, and to provide a success rating for the project. The results in Table 32 and 33 suggest that the projects that were surveyed in general achieved their main objectives or specific objectives. No single project respondent observed that the projects of which she or he had knowledge failed to achieve the objectives. A slightly more nuanced picture emerges from Table 33, which presents the responses to questions about the success ratings of the projects. Most respondents rated the projects as good or very successful (14 projects) although a larger number of respondents did not answer this question (17). The proportion of highly successful projects was highest among the special-use forest projects (5/7 projects). A larger number of the 26 protection forest projects (8) were rated from rather successful to successful, and good or very successful (6). Three projects in this category were rated moderately successful.

Table 32. Achievement of project objectives in forest rehabilitation projects

\begin{tabular}{lc}
\hline Main objectives reached & Total \\
\hline Yes & 35 \\
\hline No response & 7 \\
\hline Total & 42 \\
\hline Specific objectives reached & \\
\hline Exceeded & 1 \\
\hline Yes & 35 \\
\hline No response & 6 \\
\hline Total & 42 \\
\hline
\end{tabular}

Table 33. Success rating of forest rehabilitation projects

\begin{tabular}{lrrrr}
\hline Rating & Prod & Prot & SpU & Total \\
\hline Very successful, good (7.5-10 points) & 3 & 6 & 5 & 14 \\
\hline Successful, quite successful (7 points) & & 8 & & 8 \\
\hline Moderate (6-6.5 points) & & 3 & & 3 \\
\hline No response & 6 & 9 & 2 & 17 \\
\hline Total & 9 & 26 & 7 & 42 \\
\hline
\end{tabular}


In the sections below the report specifies the achievements of the forest rehabilitation projects in Vietnam. Most of the data presented in the subsequent sections are from the 15-project survey. This survey made it possible to obtain observations and opinions of actors closely involved in the projects, including local people, but the number of projects is small. This limits the opportunity to generalize from the results presented below.

The 15 projects yielded achievements as presented in Table 34. The first observation that can be made about this table is the wide range of achievements; 28 different achievements from only 15 projects. The 28 achievements, however, can be categorized into four groups: (1) achievements that relate to forest cover improvement and biodiversity conservation; (2) achievements that relate to the participation of and benefits to the local people and households; (3) achievements that relate to production and productivity outcomes - this is very much of interest to companies that engage in the rehabilitation of production forest land for the pulp and paper industry raw material supply; and (4) achievements that relate to technological advances important for forest rehabilitation. One additional achievement is the improvement of tourism/ ecotourism.

A comparison with the objectives of Table 26 suggests a fairly close link between objectives and achievements. Group one of the achievements (forest cover and conservation achievements) is closely related to the objectives of watershed protection/ biodiversity conservation and restoring forest cover/regreening. In similar fashion, the achievements in productivity, technology development and tourism promotion reflect the objectives in Table 26.

The poverty, rural development, and employment objectives of Table 26 are partly reflected in the achievements in Table 34, especially as intangible outcomes such as improved participation and awareness raised among local people. One outcome clearly referred to improved household income. Table 35 presents the tallied responses regarding the results of the project for local people. The table suggests some improvements in cash income and in savings, and in the variation of cash income. There was little change in food security, health and housing conditions in most projects. The improvement in education, already noticed in Table 34, is reconfirmed in this table.

Some additional information on outcomes that is relevant for households and local people, and relates to the 'poverty, rural development, and employment' objective concerns the marketable products that are being produced from the forest rehabilitation projects. This emerged from the 42-project survey. Table 36 shows that 29 out of 42 projects reported marketable products that resulted from the forest rehabilitation efforts. The most commonly reported marketable products were construction wood, timber and fuelwood.

The survey provided additional data with which to assess the forest recovery outcomes. Table 37 presents the pre-project and current forest cover, suggesting there may have been an important shift from projects that had a pre-project forest cover of $25-50 \%$, towards a current forest cover of 50-75\%. Unfortunately, a considerable number of projects (13) could not provide pre-project forest cover information, making this interpretation somewhat speculative. 
Table 34. Achievements of 42 forest rehabilitation projects

\begin{tabular}{l}
\hline Forest cover - conservation achievements \\
\hline Planting forest, and improving landscape quality (1350 ha) \\
\hline Forest cover reached proposed objective \\
\hline Restoration of barren lands in special-use forest \\
\hline 43,000 ha replanted \\
\hline 3000 ha of acacia planted between 1992-2003 \\
\hline Reforestation, tending and protection \\
\hline Core area of special-use forest well protected \\
\hline Selected appropriate species for dry and coastal areas \\
\hline Cutting of natural forest reduced \\
\hline Annual monitoring of biodiversity \\
\hline Social achievements \\
\hline People participate in reforestation \\
\hline Resettlement and training \\
\hline Training to transfer reforestation technology in alkaline soil for local staff and farmers \\
\hline Farmers have stable prices for wood \\
\hline Improvements for education, health and culture \\
\hline Lives of local people improved \\
\hline Local people participating to formulate plan and carry out forest rehabilitation and utilize \\
forest \\
\hline Assistance to ethnic groups to leave protected areas \\
\hline Productivity achievements \\
\hline Stable supply of raw material for Bai Bang \\
\hline Supply of wood to VIJACHIP \\
\hline Enhance productivity and improve quality of forest \\
\hline Teennology outcomes \\
\hline
\end{tabular}

\section{Technology outcomes}

Selection of species that are appropriate and of high economic value in alkaline soil in Cuu Long delta region

Recommended solutions to improve alkaline soil and protect water sources in the course of reforestation process

Scientific basis for forest rehabilitation after burning and plantation of production forests in Tay Nguyen

Technical and socio-economic solutions for developing production forests in Tay Nguyen Son La and Dien Bien province work out steps of land use planning

\section{Others}

Promotion of ecotourism

The 15-project survey corroborates the positive environmental outcomes suggested by Table 37 . Table 38 indicates that the majority of the 15 projects surveyed reported significant improvement or some improvement in floristic diversification, landscape diversity, soil quality and reduction of soil erosion. 
Table 35. Project outcomes for local people of 15 forest rehabilitation projects in Vietnam

\begin{tabular}{|c|c|c|c|c|c|c|}
\hline $\begin{array}{l}\text { Type of } \\
\text { change }\end{array}$ & $\begin{array}{l}\text { Remarkably } \\
\text { improved }\end{array}$ & Improved & $\begin{array}{l}\text { Little } \\
\text { change }\end{array}$ & Decreased & $\begin{array}{l}\text { No } \\
\text { data }\end{array}$ & Observations \\
\hline $\begin{array}{l}\text { Cash } \\
\text { income }\end{array}$ & 3 & 8 & 4 & & & $\begin{array}{l}\text { Mostly from } \\
\text { wages, or other } \\
\text { payments }\end{array}$ \\
\hline Savings & 9 & & 5 & & 1 & $\begin{array}{l}\text { Also } \\
\text { importantly } \\
\text { from selling } \\
\text { wood and } \\
\text { other products, } \\
\text { supplementing } \\
\text { wages }\end{array}$ \\
\hline $\begin{array}{l}\text { Non-cash } \\
\text { income }\end{array}$ & & 13 & 1 & 1 & & $\begin{array}{l}\text { Forest } \\
\text { products, } \\
\text { infrastructure, } \\
\text { improved } \\
\text { water supply, } \\
\text { training and } \\
\text { education, } \\
\text { health care }\end{array}$ \\
\hline $\begin{array}{l}\text { Variation } \\
\text { of sources } \\
\text { of cash } \\
\text { income }\end{array}$ & 8 & & 6 & & 1 & \\
\hline $\begin{array}{l}\text { Income } \\
\text { options }\end{array}$ & 3 & & 12 & & & \\
\hline $\begin{array}{l}\text { Food } \\
\text { security }\end{array}$ & 2 & & 13 & & & \\
\hline $\begin{array}{l}\text { Health } \\
\text { conditions }\end{array}$ & 3 & & 12 & & & \\
\hline $\begin{array}{l}\text { Access } \\
\text { to health } \\
\text { care }\end{array}$ & 3 & & 12 & & & \\
\hline Housing & 5 & & 10 & & & \\
\hline $\begin{array}{l}\text { Products } \\
\text { obtained } \\
\text { with high } \\
\text { value }\end{array}$ & & 1 & 14 & & & \\
\hline $\begin{array}{l}\text { Education, } \\
\text { and } \\
\text { capacity } \\
\text { building }\end{array}$ & 13 & & 2 & & & $\begin{array}{l}\text { Mostly because } \\
\text { of training }\end{array}$ \\
\hline $\begin{array}{l}\text { Market } \\
\text { access }\end{array}$ & & 10 & 5 & & & \\
\hline
\end{tabular}


Table 36. Marketable products produced from forest rehabilitation projects

\begin{tabular}{lrrrr}
\hline Marketable products & Prod & Prot & Spu & Total \\
\hline Number of projects & 9 & 26 & 7 & 42 \\
\hline Wood, construction wood, timber, fuelwood & 6 & 17 & 6 & 29 \\
\hline Other local market products & 4 & 16 & 4 & 24 \\
\hline Raw material for industry & 1 & 1 & & 2 \\
\hline Environmental services, tourism & 1 & 14 & 7 & 22 \\
\hline No data & 4 & 8 & 1 & 13 \\
\hline Total & 16 & 56 & 18 & 90 \\
\hline
\end{tabular}

Table 37. Pre-project and current forest cover in 42 forest rehabilitation projects

\begin{tabular}{lrrrr}
\hline & Prod & Prot & SpU & Total \\
\hline Pre-project forest cover & & & & \\
\hline $5-25 \%$ & 2 & 1 & & 3 \\
\hline $25-50 \%$ & 3 & 15 & 3 & 21 \\
\hline $50-75 \%$ & & 3 & 1 & 4 \\
\hline $75 \%+$ & & & 1 & 1 \\
\hline No data & 4 & 7 & 2 & 13 \\
\hline Total & 9 & 26 & 7 & 42 \\
\hline Current forest cover & & & & \\
\hline $5-25 \%$ & 2 & & & 2 \\
\hline $25-50 \%$ & 3 & 12 & 2 & 16 \\
\hline $50-75 \%$ & 3 & 13 & 3 & 20 \\
\hline $75 \%+$ & 1 & 1 & 2 & 4 \\
\hline Total & 9 & 26 & 7 & 42 \\
\hline
\end{tabular}

Table 38. Environmental changes in 15 rehabilitation projects

\begin{tabular}{lrrrr}
\hline $\begin{array}{l}\text { Type of environmental } \\
\text { change }\end{array}$ & $\begin{array}{r}\text { Remarkably } \\
\text { improved }\end{array}$ & Improved & $\begin{array}{r}\text { Little } \\
\text { change }\end{array}$ & $\begin{array}{r}\text { No } \\
\text { data }\end{array}$ \\
\hline Flora diversification & 6 & 8 & 1 & \\
\hline Diversification of landscape & 5 & 8 & 1 & 1 \\
\hline Soil erosion & 5 & 3 & 3 & 2 \\
\hline $\begin{array}{l}\text { Surface currents after project } \\
\text { implementation }\end{array}$ & 5 & & & \\
\hline $\begin{array}{l}\text { Physical and chemical features } \\
\text { of soil }\end{array}$ & 5 & 10 & & \\
\hline
\end{tabular}




\section{Reasons for Outcomes}

The survey inquired about the reasons for the achievements summarized in Table 39. A total of 24 different reasons were given, out of 39 responses. The reasons could again be grouped into six categories. Participation and support of local people, local government, and support from provincial and national authorities figured prominently (15 out of 39) among the explanations of the achievements. Another important explanation of the achievements was the monitoring that was applied to the forest rehabilitation projects. The use of appropriate techniques and adequate and timely funding are additional explanations for the achievements of the 42 forest rehabilitation projects.

Additional evidence for the outcomes of the projects survey is presented in Table 40, with answers to questions on various project management aspects. Monitoring features highly in this table. The table suggests that the quality of the management plans and the management effectiveness were quite good. However, the ability to incorporate feedback and adapt to changes scored less well.

Finally, Table 41 indicates the acceptance of the forest rehabilitation projects. Project acceptance was surveyed among three different groups: people directly participating in project activities, people living in the project area but not participating in project activities, and people living outside of the project area and not participating in the project activities. In the 15 surveyed projects, acceptance was high among all three groups. This correlates well with the high level of participation suggested by Table 39.

Table 39. Reasons for achievements in 15 projects

\begin{tabular}{lr}
\hline Reason for achievement & Frequency \\
\hline Participation of local people and authorities & \\
\hline Active involvement and support of households & 4 \\
\hline Local government and people participate actively & 3 \\
\hline Strong support from provincial, district and commune authorities & 1 \\
\hline Project implementation plan was developed by local people & 1 \\
\hline Support authorities & 4 \\
\hline High concern from national and local authorities & 1 \\
\hline Good support from DARD, PPC and others & 1 \\
\hline Good support from provincial level & 1 \\
\hline Adequate coordination & 1 \\
\hline Good collaboration between JICA and Vietnamese staff & 1 \\
\hline $\begin{array}{l}\text { National and international organizations aware of and pay attention to } \\
\text { research themes }\end{array}$ & 1 \\
\hline $\begin{array}{l}\text { Good implementation, with close cooperation between research agencies } \\
\text { and relevant districts }\end{array}$ & continued to next page \\
\hline Appropriate partner organizations selected &
\end{tabular}




\begin{tabular}{lr}
\hline Adequate and timely funding & \\
\hline Investments from Program 661 & 1 \\
\hline $\begin{array}{l}\text { Investment (Eu and GoV) in infrastructure and capacity building of staff and } \\
\text { local people }\end{array}$ & 1 \\
\hline Investment in reforestation loans, infrastructure, seedling research & 1 \\
\hline Funds provided on time & 6 \\
\hline Appropriate Monitoring & \\
\hline $\begin{array}{l}\text { Close monitoring of provincial management unit of Program 661, EU and } \\
\text { MARD and other relevant units }\end{array}$ & 3 \\
\hline Adequate technology & 1 \\
\hline Applying advanced technology & 1 \\
\hline Compliance with reforestation techniques & 1 \\
\hline $\begin{array}{l}\text { Good investment method for afforestation in line with natural and socio- } \\
\text { economic conditions of project areas }\end{array}$ & 1 \\
\hline Others & 1 \\
\hline Effective protection methods (fences, guards, fines) & 1 \\
\hline Adequate improvements in buffer zone & 39 \\
\hline Project design matches socio-economic and land condition of target areas \\
\hline Project has long-term experience with project area & 1 \\
\hline Upgrade of nature reserve to national park & \\
\hline Total & \\
\hline
\end{tabular}

Table 40. Management improvements in 15 forest rehabilitation projects

\begin{tabular}{lrrrr}
\hline $\begin{array}{l}\text { Management aspects of forest } \\
\text { rehabilitation projects }\end{array}$ & $\begin{array}{c}\text { Remarkably } \\
\text { improved }\end{array}$ & Improved & $\begin{array}{r}\text { Not much } \\
\text { improved, } \\
\text { no change }\end{array}$ & $\begin{array}{r}\text { No data/ } \\
\text { not } \\
\text { applicable }\end{array}$ \\
\hline $\begin{array}{l}\text { Stable market and support } \\
\text { policy for products obtained } \\
\text { from rehabilitated forest }\end{array}$ & 4 & 3 & 4 & 4 \\
\hline $\begin{array}{l}\text { Effectiveness of monitoring and } \\
\text { evaluation }\end{array}$ & 9 & 4 & 1 & 1 \\
\hline Incorporation of feedback & 2 & 10 & & \\
\hline Quality of management plan & 8 & 4 & 2 & 1 \\
\hline Effectiveness of management & 7 & 3 & 2 & 1 \\
\hline Re-investment mechanism & 4 & 3 & 1 & 7 \\
\hline Adaptability to changes & 4 & 4 & 3 & 4 \\
\hline Social conflicts & 3 & 1 & 4 & 7 \\
\hline $\begin{array}{l}\text { Institutions that address } \\
\text { enabling environment }\end{array}$ & 5 & 5 & 1 & 4 \\
\hline
\end{tabular}


Table 41. Acceptance of forest rehabilitation projects

\begin{tabular}{lrrrr}
\hline Acceptance & $\begin{array}{r}\text { Remarkably } \\
\text { improved }\end{array}$ & Improved & $\begin{array}{r}\text { Little improved, } \\
\text { no change }\end{array}$ & No data \\
\hline Acceptance from participants & 10 & 8 & 1 & 4 \\
\hline $\begin{array}{l}\text { Acceptance from non } \\
\text { participants in project area }\end{array}$ & 8 & & 1 & 4 \\
\hline $\begin{array}{l}\text { Acceptance from non } \\
\text { participants outside project } \\
\text { area }\end{array}$ & 8 & 1 & 2 & 4 \\
\hline
\end{tabular}




\section{Chapter 5 \\ Lessons Learnt}

This chapter draws lessons from the results of the study presented in Chapters Two, Three and Four. The chapter will start with an overview of the results of 50 years of forest rehabilitation in Vietnam and then will try to explain these outcomes, using the framework presented in Chapter One.

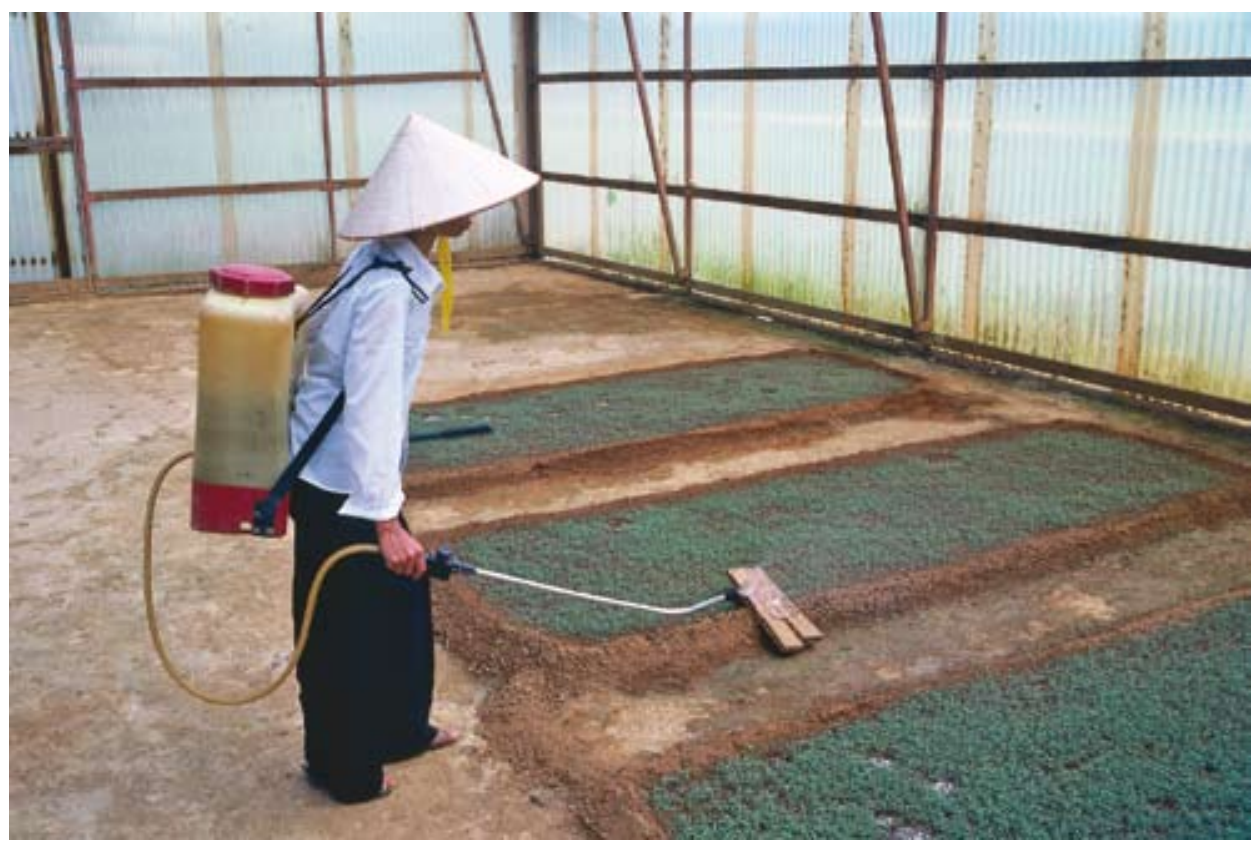

Bai Bang road. Nursery of the forest research center - Vietnam. (Photo by Christian Cossalter) 


\section{The Results of 50 Years of Forest Rehabilitation}

Vietnam has a long history of forest rehabilitation, as it started to give tree planting its due importance in the mid-1950s. The country has since then spent a great deal of effort on bringing back tree vegetation where forests have disappeared. There is less evidence, however, of how successful these efforts have been, what the economic, social and political costs have been, and how much benefit they have yielded.

There are various indicators that demonstrate the success of Vietnam's forest rehabilitation. Chapter Four of this report argues that over $85 \%$ of the projects that were surveyed as part of this report had met their main and specific objectives (Table 32). The people who provided success ratings of their projects rated over $50 \%$ as successful or good, while over $80 \%$ of the projects rated between quite successful and very successful (Table 33). These qualifications, however, were not based on rigid criteria, and were made by people who may have had an interest in presenting the projects as successful.

Most of the forest rehabilitation projects included in the surveys had more than one objective (Table 26). The objectives related to restoration of forest cover for productivity, environmental functions including biodiversity conservation, but also local and wider development objectives. The multiple objectives are a common feature in the majority of projects despite the dominance of forest rehabilitation on protection forest land.

Table 34 in Chapter Four indicates that project achievements fairly well matched the objectives. Table 26, however, does not include any political objectives, such as, for instance, improving participation of the rural poor in political processes. Some of the achievements, however, do suggest that this has been an additional outcome of some of Vietnam's forest rehabilitation projects, as they have improved dialogue between the authorities and other stakeholders.

A different indicator that reflects the success of Vietnam's forest rehabilitation is the relation between areas rehabilitated, and the existing area of rehabilitated forest at various points in history. As reported in Chapter Three, the available data suggest that plantation forest area has increased markedly year by year: 1,050 million ha in 1995; 1,471 million ha in 2000, 2,218 million ha in 2004. Figure 1 of this report, which presents the official data used by the GoV (2005) gives a plantation forest area of 745,000 ha in 1990 . There is no indication of how much forest had been rehabilitated naturally until the early 1990s as a result of active protection or abandonment. However, it is obvious that maintenance and assisted natural regeneration of exhausted forests, especially in watershed areas, has contributed to the increase in forest coverage. Up to the year 2005, assisted natural regeneration has been applied in an area of 723,450 ha of forest under the 5MHRP (accomplishing $72 \%$ of the plan). In 1995 forest covered only $28 \%$ of the country, but this figure increased to $35 \%$ and $36.7 \%$ in 2000 and 2004 , respectively.

Program 327 established between 397,000 and 640,000 ha of new plantations and protected or enriched between 299,000 and 700,000 ha of forests. As suggested by Do Dinh Sam et al. (2004), by 2003, the 5MHRP had established 1.71 million ha of forests. According to the MARD report on the achievements of the 5MHRP, until 
2005, an area of 1,401,667 ha of plantation forest had been established, of which 631,317 ha was protection and special-use forest, 683,396 ha was production forest, and 86,954 ha was fruit tree and industrial crop plantation on forestry land.

We can present only a summary and a fragmented picture of the economic, social and political costs and benefits of forest rehabilitation. As reported in Chapter Two, forest plantations have progressively contributed to wood supply in Vietnam. In 2001 the forestry industry consumed 1.6 million $\mathrm{m}^{3}$ of forest plantation wood. In addition, close to a third of Vietnam's saw wood demand is met from rubber and pine plantations (JPD 2001). It is difficult to establish how much forest rehabilitation has contributed to the total role of the forestry industry in the national GDP, estimated at $6 \%$ by Castrén (1999). With an area of over 2 million ha, special-use forests, including national parks and natural reserves, have huge advantages in biodiversity and gene conservation.

The results presented in Chapter Four suggest positive outcomes of forest rehabilitation for local communities. Local people were mentioned as one group of beneficiaries in all the 42 projects that we surveyed. They obtained benefits in terms of cash income, savings and non-cash incomes, forest protection contracts, use of fuelwood from non-timber forest products and improvements in education. There was little or no improvement in food security, health conditions, access to health care or housing (Table 35). These results are from a small sample of 15 projects. The results presented in Chapter Four also suggested positive environmental outcomes of the forest rehabilitation projects in terms of floristic diversification, landscape diversity, soil quality and reduction of soil erosion (Table 38). Many projects achieved a recuperation of forest cover.

\section{Explaining Outcomes}

We will use the conceptual framework summarized in Table 2 (Chapter One) to explain the outcomes of forest rehabilitation in Vietnam. Table 2 presents the conceptual framework of conditions that need to be met for successful forest rehabilitation. These include policy, actors and their organization, funding, objectives of rehabilitation, economics and markets, and technology, forestry extension, technical assistance and training.

\section{Policy and Legislation}

The policy and legislation in Vietnam has, compared to other countries, been highly conducive to forest rehabilitation. The GoV has made forest rehabilitation a priority since the mid-1950s, and this commitment has been boosted since the early 1990s. The policy of forest rehabilitation has been clearly reflected through the projects carried out at the national scale. Various projects and programs in the field of forest rehabilitation have been implemented consecutively over many years. The World Food Program, which was launched in Vietnam in 1975 by FAO, allocated a substantial amount of its budget for implementing afforestation projects, enhancement of forestry extension services, and agroforestry production on sloping 
land. Subsequently, Program 327 was initiated in 1992 with various objectives. The program initially targeted broad areas including forestry, agriculture, fishery, sedentarization and the development of new economic zones, but later focused on the protection and rehabilitation of special-use and protection forests. The continuation of Program 327-the 5MHRP, also known as the 661 project - is one among the key national projects approved by the National Assembly. The Project will terminate in 2010. Both Program 327 and the 661 project demonstrate the state's concerns about the rehabilitation of special-use and protection forest and the related commitment of state funds for forest rehabilitation. The protection function of forests, forest environment and conservation of forest biodiversity are clearly taken into account.

The successful results of forest rehabilitation also depend greatly on sectoral and non-sectoral policies, as explained in Chapter Two. The conceptual framework in Table 2 emphasizes the policies related to land ownership, support, incentives, land use planning and environmental services. Particularly relevant have been the revisions of the Land Law (in 1993, 1998, 2000 and 2003) and the enactment of the Forest Protection and Development Law. The Land Law clearly states that the land is planned and generally managed by the state but can be allocated to individuals, households, social organizations and communities for long-term use in compliance with agreed purposes. Rights are quite comprehensive as owners can exchange, transfer or inherit land use rights, or use the land as collateral for bank loans. The Forest Protection and Development Law defines the legal opportunities for forest land allocation and the leasing of forests to individuals, households, management boards, economic organizations and communities. The Law indicates the state policy of investing in, encouraging and supporting forest protection and development; expanding the market for forestry products and insuring plantation forest. There are also a number of decrees and decisions issued by the government regarding land allocation and forest contracting, as mentioned in Chapter Two (Decree 01, 02, 163); beneficiary policy (Decision 178, Decision 08); support and credit policies for forest protection and development (Decision 661). Many policies have been endorsed and amended to make them consistent with the actual situation. For example, amendments are currently being made to Decision 08 regarding the management of protection forest, special-use forest and production forest categorized as natural forest, and to Decision 178 regarding beneficiary policy.

National policies and legislation are being adjusted to reflect new opportunities and needs. The Environment Protection Law, for instance, was revised in 2005, as was the Forest Protection and Development Law, to better assess the role of forests in the provision of environmental services, and to open opportunities for compensation where these services are being provided.

The policy environment, however, does have its limitations, as has been pointed out in quite a few studies and reports, many of which have been included in the literature list below (e.g. Poffenberger and Nguyen H.P. 1998; MARD 2001). Policies may contradict each other, they are poorly communicated to lower administrative levels, and their implementation is poorly monitored, resulting in divergent implementations in different parts of the country. Although forest land is given out in tenure the 
progress of this process is slow, while the incentives for forest rehabilitation are often not optimal. Credit policies and credit provisions do not meet the requirements of many new forest owners.

Despite the many shortcomings, however, environmental policy and legislation in Vietnam can be singled out as one of the key factors that has contributed positively to the country's achievements in forest rehabilitation.

\section{Actors and Arrangements}

The actors and arrangements related to forest rehabilitation present a mixed picture. The institutional dimension of Vietnam's forestry sector is still very much influenced by its political legacy of centralized, top-down decision making. Government agencies dominate forestry issues at the national, provincial, district and commune levels. A clear indication is that the execution of forest rehabilitation projects is in the majority of cases under control of a state or related agency. The role of the State Forestry Enterprises is still considerable. This resulted in significant use of forest rehabilitation funds for other purposes under Program 327 (Chapter Two). Government actors have conflicting interests and still dominate decision making where the consent and collaboration of non-state actors, including rural people, is a key requirement for success. In practice, many forest protection and special-use restoration projects are funded by the state budget and managed by Project Management Boards. Encouraging new initiatives that explore alternatives to these patterns give hope for the future. For instance, forest rehabilitation projects supported by the German KfW have successfully experimented with far-reaching participation of local people in decision making.

On the other hand, there is evidence that the implementation of forest rehabilitation projects has been effective. The results suggest that the management of forest rehabilitation projects was good. In particular, project monitoring, the quality of the management plans and the management effectiveness, and, to a lesser extent, the ability to incorporate feedback and adapt to change, were emphasized as elements contributing to success.

Provincial actors have had ambiguous roles in implementing forest rehabilitation programs. There is autonomy at the provincial level to decide on the forest type status of the land. In many instances production forest lands have been reconverted to protection forest or special-use forest, with the specific objective of capturing more of the forest rehabilitation funds made available by the central government. The areas of these two forest types are currently being re-examined and reduced to more accurately reflect the need for protection and special-use forests.

Vietnam knows little of the types of conflicts that have characterized other countries where forest rehabilitation projects have conflicted with the interests of key stakeholders. Social cohesion is problematic in some regions, like for instance the Central Highlands (Tran V.C. 2006; Potter 2006), but this is not a general condition of locations where forest rehabilitation takes place. A related issue is the statistics on land available or in need of forest rehabilitation. This figure is estimated to be approximately 7 million ha. Commentators, however, hold that much of this 
area is actually being used by local dwellers. Thus, it is difficult to reclaim those areas as it may be difficult to find a concentrated land reserve for industrial forest development.

We do not want to exclude the possibility that the absence of conflicts may in part be a result of Vietnam's persistent state presence and the still-limited opportunities to express divergent opinions. In general, however, the perception that forest rehabilitation is relevant and important is widely shared, and the institutional arrangements are clear, although the terms of the arrangements are not always adequate (i.e. forest protection contracts). The positive participation and support of local people, local government, and support from provincial and national authorities in forest rehabilitation has been mentioned in Chapter Four.

The availability of rehabilitation project information, including major documents, and dissemination of project outputs are inadequately dealt with. Project information is irregularly updated and this makes it difficult to compile necessary information from each project. The better sources of information are usually provided by foreignfunded projects.

\section{Funding}

Vietnam has for many years invested considerable amounts of funds in forest rehabilitation, especially since the 1990s. This national investment has been complemented with significant international support. Despite the amounts invested, Do Dinh Sam et al. (2004) observes that funding has been inadequate to achieve the targets set under various programs. Under current arrangements of payments for the protection of forests, state financing of forest protection needs to continue if the forests are to be kept, although the sustainability of payments for forest protection might be questioned (MARD 2001). There is little other funding being mobilized for forest rehabilitation, especially for the rehabilitation of production forest land that is meant to boost the forestry sector's contribution to the national economy. Various authors (e.g. JPD 2001; Lang 2002) have pointed out that Vietnam's production forestry is hindered by biophysical, technological and institutional constraints. This may imply that some of the ambitious plans that Vietnam has for its productive forestry sector, as explained in Chapter Two, may only be achievable with considerable state financial contributions.

This funding situation does not translate to optimal conditions for smallholders. Some payments, such as for forest protection contracts, are perceived to be too low. Credits available for forest rehabilitation do have very favourable conditions, but even those conditions still do not convince many farmers that investing in forest rehabilitation is worth their while.

\section{Objectives of Rehabilitation}

The objectives that are pursued in Vietnam's forest rehabilitation include environmental, economic and social objectives (Table 26). The objectives are fairly compatible. Productive objectives can be carried out on production forest land, and in principle these objectives can be compatible with social objectives, like improving the 
well-being of the rural poor. In practice, however, the link between those objectives is difficult in Vietnam, as it is in many other locations in the world. Prices paid for wood and timber are limited by profit margins, and they may be too low to be attractive to small scale tree growers. Local markets for wood or other forest products may be limited. Commercially interested entrepreneurs may have little interest in dealing with many small producers. These are all constraints that diminish the compatibility of various objectives of forest rehabilitation as listed in Table 26.

The objectives of forest rehabilitation are relatively flexible and can be adjusted if needed. For example, as mentioned above, considerations are currently being made regarding narrowing the area of protection and special-use forest, and expanding the area of production forest.

\section{Economics, Markets and Demand}

Various arguments have been already stressed in the previous paragraphs related to economics, markets and demand. The woodchip and derivatives sector may suffer from high production costs, in which case nationally produced products may end up being more expensive than those produced elsewhere (Lang 2002). New product development will be an important aspect that will have to be addressed if the planned expansion is to be successful, and forest rehabilitation on production forest land economically viable. The more environmental function-oriented forest rehabilitation does not appear likely to become profitable any time soon, while some of the anticipated benefits that stimulated forest rehabilitation may not be realized because of the unclear link between forest cover and downstream flooding, or limited water volumes.

Recently, although forest plantation has increased it contribution to covering the need for industrial materials such as paper, fibre and particle board, and woodchips, the demands remain large. In the last two years, for instance, furniture exports have increased vigorously, yet $80 \%$ of raw materials are from imports. Thus forest plantations to improve timber supplies become more and more urgent. More effort should be made to meet current and future demand for wood materials.

\section{Technology, Extension, Technical Assistance and Training}

Various commentators on Vietnam's forestry sector have observed technical limitations to forest rehabilitation, including inadequate seed material, poor soils in plantation sites, and inadequate plantation maintenance (JPD, 2001; Castrén 1999). These observations, however, contradict with some the conclusions from Chapter Three of the accumulated experiences and know how related to tree plantations. This aspect of forest rehabilitation appears to be changing quickly. Forest rehabilitation these days includes many technical approaches, including agroforestry, intercropping and natural regeneration. The results of this study suggest that some form of plantation, however, continues to be the dominant method of forest rehabilitation. It should be acknowledged that science and technology, as well as the application of advanced techniques in production, have contributed significantly to the outputs of forest rehabilitation in Vietnam. A group of tree species that have high productivity, are 
economically and environmentally valuable, and can grow on the degraded barren hilly land, sandy coastal and drought-stricken areas, has been available since the early 1990s. Advanced methods in terms of breed improvement, intensive afforestation, productivity increases, and planting site selection have been widely applied in the field. Good results for natural forest rehabilitation through maintenance, assisted regeneration and enrichment planting have also been achieved through the application of techniques obtained from relevant research. However, the need to improve tree productivity and the supply of high quality tree breeds remains.

The forestry extension service has drawn attention. Agriculture and forestry extension organizations, as well as governmental extension programs, have been established from the central to the local level. A number of projects for agriculture and forestry extension have been implemented. However, the effectiveness of the service is still unsatisfactory. In many cases, top-down approaches, already mentioned above, continue to characterize forestry extension.

\section{Lessons learnt}

The following key lessons can be synthesized from the success and shortcomings of Vietnam's forest rehabilitation:

1. Forest rehabilitation should be incorporated in projects and programs at the national level and implemented through projects at the local level with well-defined goals. The more detailed the project objectives and plans of operations are, the more the project achievements will reflect the goals and objectives.

2. Theprocedureofprojectappraisal, management and monitoring of project operation is essential to ensure the success of the projects. At present, because of inadequate appraisal, the number of projects that focus on protection and special-use forest have exceeded

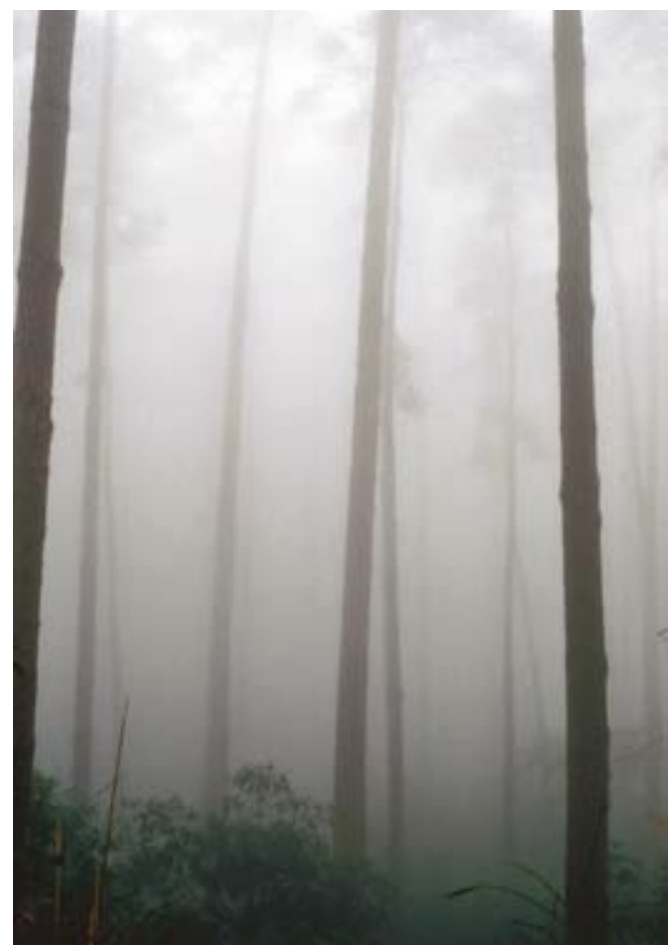

Fog in Pinus massoniana plantation, north Vietnam. (Photo by Christian Cossalter) the tentative plan until 2010. One key defining factor of success for the 5MHRP is adequate but relevant coordination from the central to local level, all the way to households and communities.

3. Clear and detailed benefits for households and articulated participation will vastly enhance project results. 
4. Clarifying land ownership conditions for the party that will hold key responsibility for the rehabilitation, and adequately addressing technical requirements, will also enhance project results.

5. The implementation of forest rehabilitation projects should be integrated with other projects that aim to improve the socio-economic conditions of local populations.

6. Forest rehabilitation projects should be combined with other supporting activities to ensure that the major goals of the projects are met. 



\section{References}

Carew-Reid, J.S. et al. 1999. A Study on Aid to the Environment Sector in Viet Nam. MARD, UNDP-Vietnam. Hanoi.

Castrén, T. 1999. Timber trade and wood flow study, Vietnam. Regional Environmental Technical Assistance 5771. Poverty Reduction and Environmental Management in Remote Greater Mekong Subregion (GMS) Watersheds (Project Phase 1)

Clarke, J.E. n.d. Biodiversity and protected areas. Regional Environmental Technical Assistance 5771. Poverty Reduction \& Environmental Management in remote Greater Mekong Subregion Watershed Project, Phase 1. www.mekonginfo.org.

Do Dinh Sam, Trieu Van Hung, Pham Ngoc Mau and De Jong, W. 2004. How does Vietnam Rehabilitate its Forests? www.cifor.cgiar.org/rehab/.

Food and Agriculture Organization of the United Nations (FAO)-CIFOR. 2005. Forests and floods: Drowning in fiction or driving on facts. RAP publication 2005/03. Forest Perspectives 2. Center for International Forestry Research, Bogor, Indonesia.

Forest Inventory and Planning Institute (FIPI). 1995. Investigation, evaluation and monitor of forest resource changing in the whole country 1991-1995. Hanoi, FIPI.

Forest Protection Department (FPD). 2006. List of special use forest system. Viet Nam Forestry Development Strategy from 2006 to 2020 (draft), Annex 16. Hanoi, MARD.

Government of Vietnam (GoV). 2005. National Report to the Fifth Session of the United Nations Forum on Forests. http://www.un.org/esa/forests/pdf/national_ reports/unff5/vietnam.pdf.

International Center for Environmental Management (ICEM). 2003. Vietnam National Report on Protected Areas and Development. Review of Protected Areas and Development in the Lower Mekong River Region, International Center for Environmental Management. Indooroopilly, Queensland, Australia. 60 pp. 
Jaakko Pöyry Development (JPD). 2001. The development potential of Vietnam's wood growing sector. Jaakko Pöyry Development. Report prepared for the World Bank.

Lamb, D. and Gilmour, D. 2003. Rehabilitation and restoration of degraded forests. IUCN, Gland, Switzerland and Cambridge, UK and WWF, Gland, Switzerland.

Lang, C. 2002. The pulp invasion. World Rainforest Movement, Montevideo.

McElwee, P. 2001. Fuelwood Harvesting and Use in Cam Xuyen District, Ha Tinh Province. Non-Timber Forest Products Research Center, Forest Science Institute of Vietnam, Hanoi, Vietnam.

Ministry of Agriculture and Rural Development (MARD). 1998. Evaluation report of technical issues of 6-year implementation of 327 Programme. Ministry of Agriculture and Rural Development, Hanoi.

Ministry of Agriculture and Rural Development (MARD). 2001. Five Million Hectare Reforestation Program and Partnership: Synthesis report. 5MHRP Partnership Secretariat, International Cooperation Department, Ministry of Agriculture and Rural Development, Hanoi.

Ministry of Agriculture and Rural Development. 2004. Forest land and unused land for forestry planning. Hanoi, MARD.

Ministry of Agriculture and Rural Development. 2005. Conclusion of Deputy Prime Minister Nguyen Tan Dung in the meeting of evaluation of the implementation of 5 million hectare forestation project and forest protection. Science and Technology Journal of Agriculture and rural Development.

Ministry of Agriculture and Rural Development (MARD). 2006. The National Forest Strategy for the Period 2006-2020, draft. Ministry of Agriculture and Rural Development, Hanoi.

Ministry of Forestry (MoF). 1991. Forestry Sector Development for 30 years from 1961 to 1990. Statistical Publishing House, Hanoi.

Ministry of Natural Resource and the Environment (MONRE). 2003. Manual for forestry sector - Chapter on natural environment and forestry in Viet Nam.

Morris, J., Le Thi Phi, A. Ingles, J. Raintree and Nguyen V. D. 2003. Linking Poverty Reduction with Forest Conservation. Cambridge, IUCN - The World Conservation Union.

Nguyen N. B. 2003. The situation of the implementation of the 5 million hectare forestation project in the period 1998-2003. Special Publication of Science and Technology Journal of Agriculture and Rural Development.

Nguyen, N. L. 1996. Industrial plantations in Vietnam and their future development. In FAO, MARD, JICA: National workshop on strengthening industrial forest plantation in Vietnam, pp 4-16. FAO, Hanoi.

Nguyen S.C. 2003. Agriculture, Vietnam's rural area during the renovation period. Statistics Publishing House, Hanoi.

Nguyen, T.Q. 2005. What benefits and for whom? Effects of devolution of forest management in Dak Lak, Vietnam. Shaker Verlag, Aachen. 
Nguyen V. S. and Gilmour, D. 1999. Forest rehabilitation policy and practice in Vietnam. IUCN, Hanoi.

Nguyen Van Thinh, Pham Minh Thoa, Ho Viet Sac, Oystein Botillen, Vu Hoai Minh and Warfinge, H. 2000. Field assessment of projects in the national five million hectare reforestation programme. MARD, UNDP PROFOR Vietnam, Hanoi.

Nguyen X. N. 2001. Experiences and future directions of forestry funding in Vietnam. International workshop on financing sustainable forest management. In: Chipeta,

M.E.; Joshi, M. (eds.) Financing sustainable forest management: Proceedings of an international workshop, Oslo, Norway, 22-25 January 2001. Center for International Forestry Research, Bogor. 1 CD-ROM.

Phan, T. H. and Wattez, E. 1991. A compendium of environmental projects in Vietnam, 1985-1995. UND, Hanoi.

Planet Ark. 2005. Drought Makes Vietnam Double Chinese Power Imports. http:// www.planetark.com/dailynewsstory.cfm/newsid/30721/story.htm.

Poffenberger, M. and Nguyen H. P. 1998. The national forest sector. Part 1. In: Poffenberger, M. (ed.) Stewards of Vietnam's Upland Forests. Asia Forest Network andForestInventoryandPlanningInstitute.www.communityforestryinternational. org.

Potter, L. 2006. An Overview of Migration and Deforestation In Southeast Asia: 1880 To 2002. Chapter 8 in: W. de Jong, T.P. Lye and K. Abe. Migration and the Social Ecology of Tropical Forest. Kyoto University Press, Kyoto, and Transpacific Press.

Poulsen, J. et al. 2002. Typology of planted forests. CIFOR Info brief. http://www. cifor.cgiar.org.

Raintree J.B., Le Thi Phi and Nguyen Van Duong. 1999. Report on a diagnostic survey of conservation problems and development opportunities in Khang Ninh Commune in the buffer zone of Ba Be National Park. Project on Sustainable Utilization of Non- Timber Forest Products. Forest Science Institute of Vietnam, Hanoi.

Salmi, J., Nguyen Xuan Nguyen and Le Luang Trung. 1999. Study on financing strategy for sustainable forest management in Vietnam.

Sikor, T. 1998. Forest policy reform: From state to household forestry. In: Poffenberger, P. (ed.) Stewards of Vietnam's Upland Forests, 118-138. Research Network Report Number 10. Asian Forestry Network.

Sikor, T. 2001. The allocation of forestry lands in Vietnam: Did it cause the expansion of forests in the northwest. Forest Policy and Economics 2:1-11.

Sikor, T. and Apel, U. 1998. The Possibilities for Community Forestry in Vietnam. Asia Forest Network Working Paper Series. Asia Forest Network, Santa Barbara, California, USA.

Smith, J. 2002. Afforestation and reforestation in the clean development mechanism of the Kyoto Protocol: implications for forests and forest people. Int. J. Global Environmental Issues 2: 322-343. 
Sunderlin, W. and Huynh, T.B. 2004. Poverty alleviation and forests in Vietnam. Center for International Forestry Research, Bogor.

Tran, V.C. 2006. Migration and Tropical Forests in the Central Highlands of Vietnam. In: de Jong, W., Lye, T.P. and Abe, K. (eds.) Migration and the Social Ecology of Tropical Forest. Chapter 11. Kyoto University Press, Kyoto, and Transpacific Press. 


\section{Review of Forest Rehabilitation Lessons from the Past}

\section{SERIES}

Rehabilitación de áreas degradadas en la Amazonía peruana

Revisión de experiencias y lecciones aprendidas

Recuperação de áreas alteradas na Amazônia brasileira

Experiências locais, lições aprendidas e implicações para políticas públicas

\section{Learning lessons from China's} forest rehabilitation efforts

National level review and special focus on Guangdong Province

Forest rehabilitation in Indonesia

Where to after three decades?

One century of forest rehabilitation in the Philippines

Approaches, outcomes and lessons

\section{Forest rehabilitation in Vietnam}

Histories, realities and future 
